LA-12905-SR

Status Report

UC-810

Issued: May 1995

Los Alamos National Laboratory

Yucca Mountain Site Characterization Project 1993 Quality Program Status Report

Stephen L. Boliver 



\section{DISCLAIMER}

This report was prepared as an account of work sponsored by an agency of the United States Government. Neither the United States Government nor any agency thereof, nor any of their employees, make any warranty, express or implied, or assumes any legal liability or responsibility for the accuracy, completeness, or usefulness of any information, apparatus, product, or process disclosed, or represents that its use would not infringe privately owned rights. Reference herein to any specific commercial product, process, or service by trade name, trademark, manufacturer, or otherwise does not necessarily constitute or imply its endorsement, recommendation, or favoring by the United States Government or any agency thereof. The views and opinions of authors expressed herein do not necessarily state or reflect those of the United States Government or any agency thereof. 


\section{DISCLAIMER}

Portions of this document may be illegible in electronic image products. Images are produced from the best available original document. 


\section{TABLE OF CONTENTS}

Abstract $\ldots \ldots \ldots \ldots \ldots \ldots \ldots \ldots \ldots \ldots \ldots \ldots \ldots \ldots \ldots \ldots \ldots \ldots \ldots \ldots \ldots$

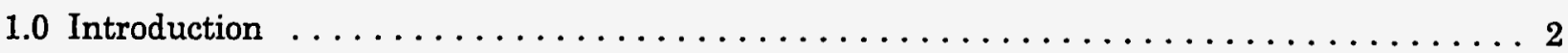

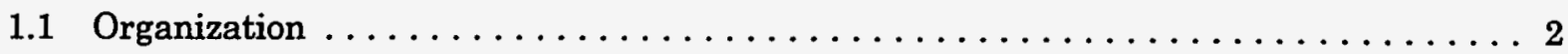

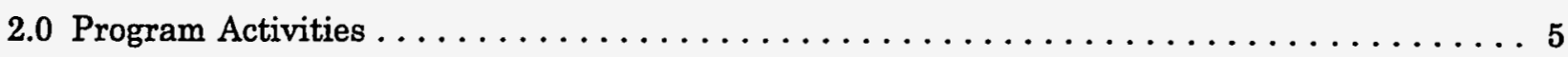

2.1 Program Development $\ldots \ldots \ldots \ldots \ldots \ldots \ldots \ldots \ldots \ldots \ldots \ldots \ldots \ldots \ldots \ldots \ldots$

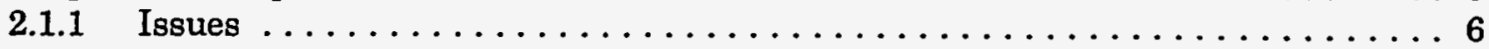

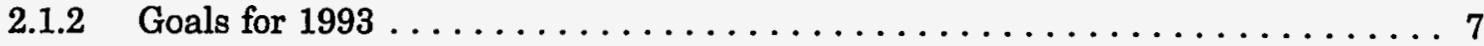

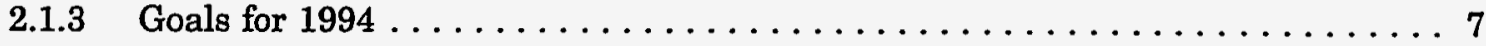

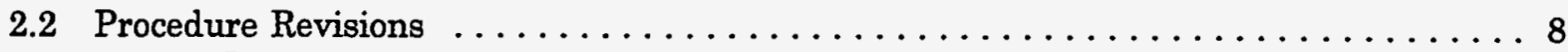

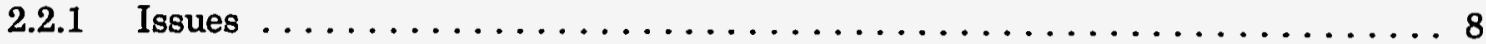

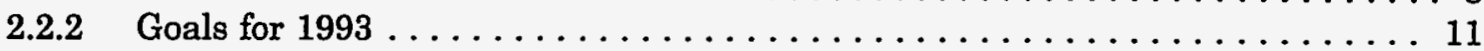

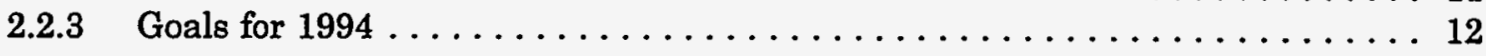

2.3 Measuring and Test Equipment (M\&TE) $\ldots \ldots \ldots \ldots \ldots \ldots \ldots \ldots \ldots \ldots \ldots$

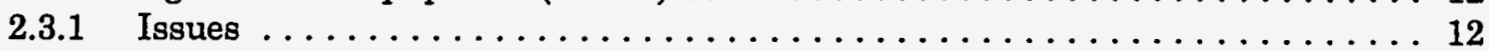

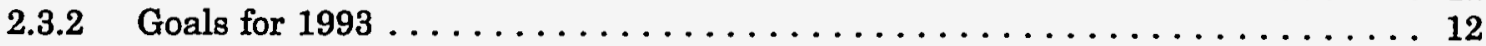

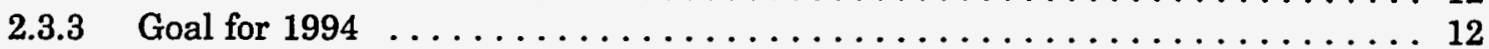

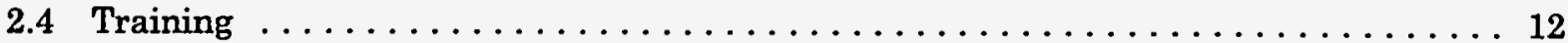

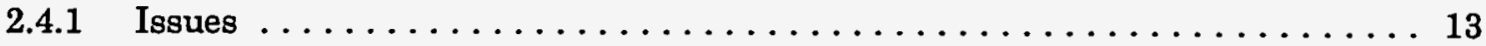

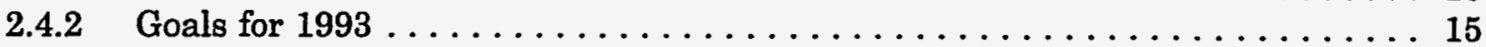

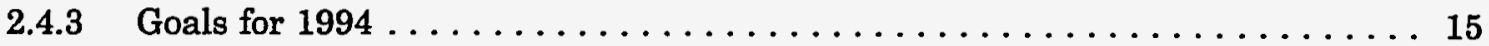

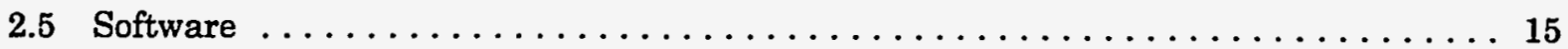

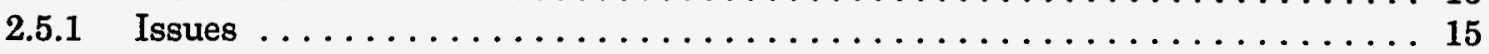

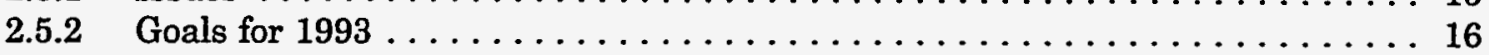

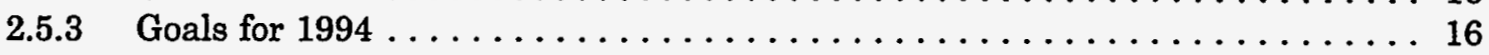

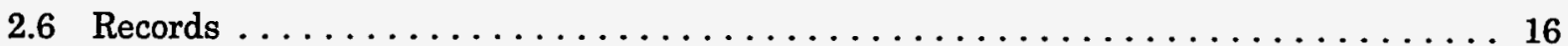

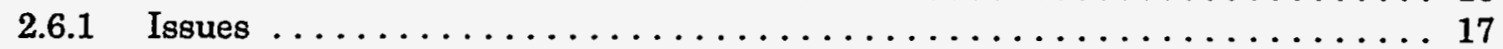

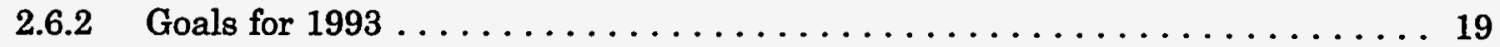

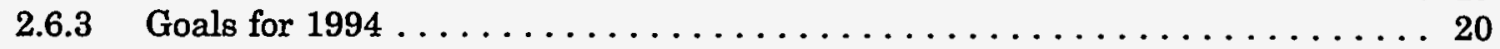

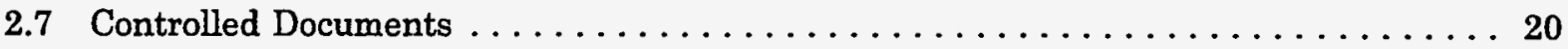

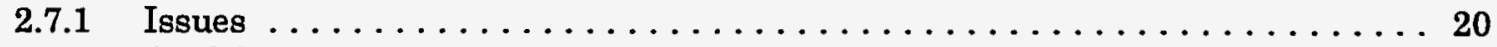

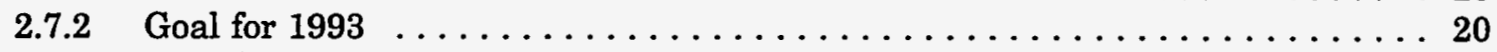

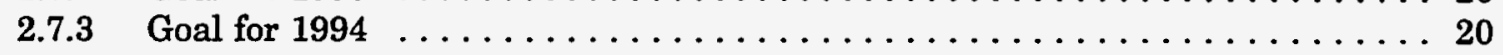

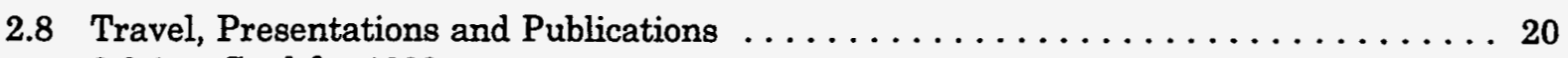

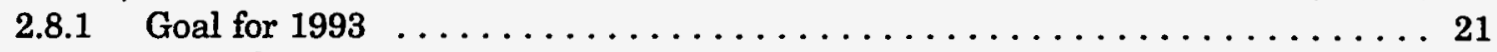

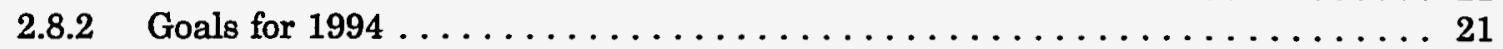




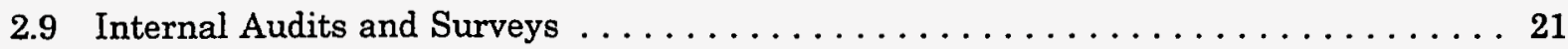

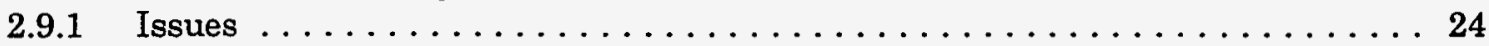

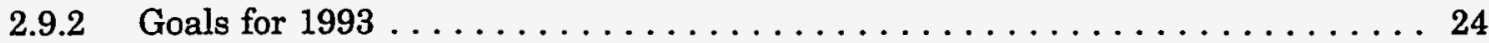

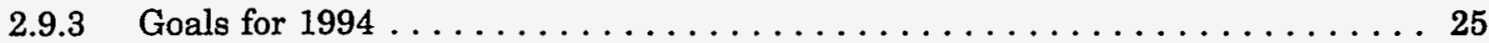

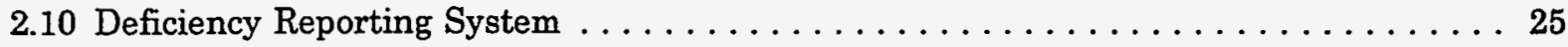

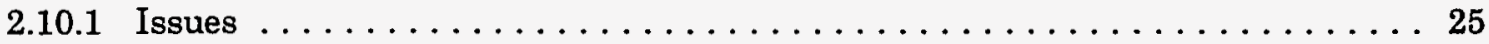

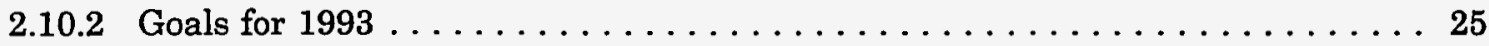

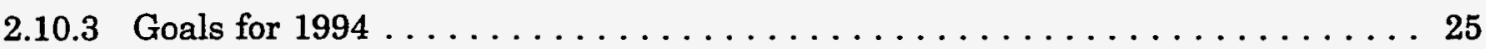

2.11 Efforts to Increase Awareness of the Quality Program . . . . . . . . . . . 28

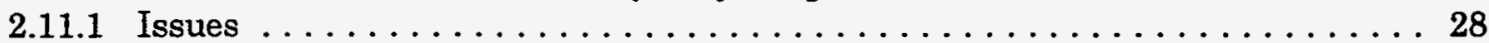

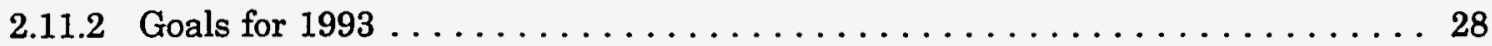

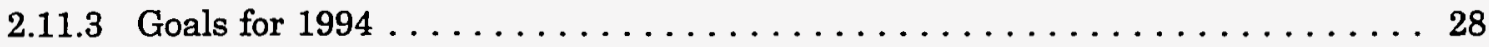

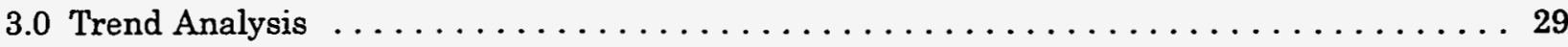

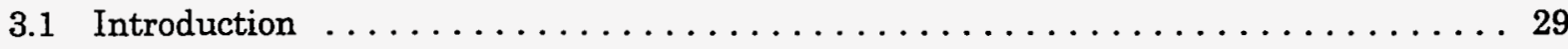

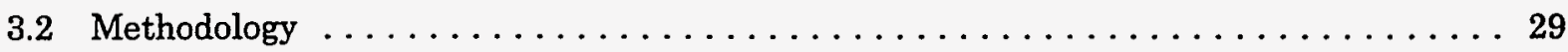

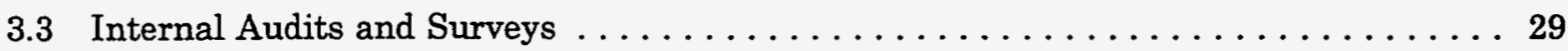

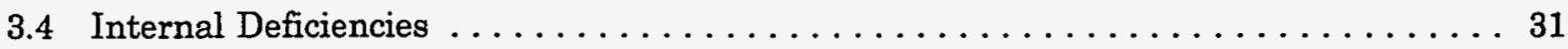

3.5 Stop Work Orders and Conflict Resolutions $\ldots \ldots \ldots \ldots \ldots \ldots \ldots \ldots \ldots \ldots \ldots$

3.6 DOE Audits, Surveillances, and Issued Deficiencies $\ldots \ldots \ldots \ldots \ldots \ldots \ldots \ldots$

3.7 Status of Adverse Trend and Significant Conditions Adverse to Quality . . . . . . 31

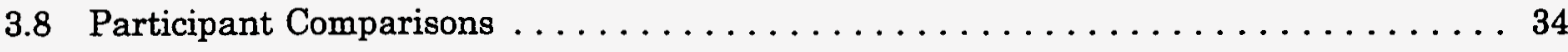

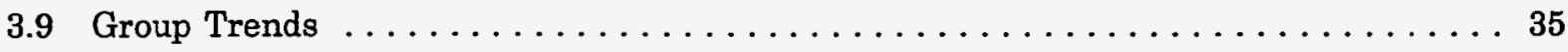

3.10 Possible Adverse Trends Associated with Criteria or Procedures . . . . . . . . 40

3.11 Trends Identified with Probable Cause Determination $\ldots \ldots \ldots \ldots \ldots \ldots \ldots$

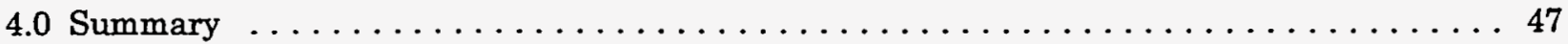

5.0 References $\ldots \ldots \ldots \ldots \ldots \ldots \ldots \ldots \ldots \ldots \ldots \ldots \ldots \ldots \ldots \ldots \ldots \ldots \ldots \ldots$

Acknowledgments $\ldots \ldots \ldots \ldots \ldots \ldots \ldots \ldots \ldots \ldots \ldots \ldots \ldots \ldots \ldots \ldots \ldots$

Appendix A Q Team Charter . . . . . . . . . . . . . . . . . . 49

Appendix B Training Classes Provided in $1993 \ldots \ldots \ldots \ldots \ldots \ldots \ldots \ldots \ldots \ldots \ldots \ldots$

Appendix C Software Management Status Report $\ldots \ldots \ldots \ldots \ldots \ldots \ldots \ldots \ldots \ldots$

Appendix D Controlled Documents Issued in $1993 \ldots \ldots \ldots \ldots \ldots \ldots \ldots \ldots \ldots$

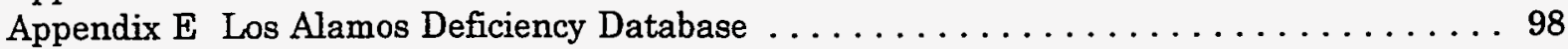




\title{
LOS ALAMOS NATIONAL LABORATORY YUCCA MOUNTAIN SITE CHARACTERIZATION PROJECT 1993 QUALITY PROGRAM STATUS REPORT \\ by
}

\author{
Stephen L. Bolivar
}

\begin{abstract}
This status report summarizes the activities and accomplishments of the Los Alamos Yucca Mountain Site Characterization Project's quality assurance program for calendar year 1993. The report includes major sections on Program Activities and Trend Analysis.

Program Activities are discussed periodically at quality meetings. The most consuming issue addressed in 1993 has been the revision of all quality administrative procedures and selected training classes to better meet the requirements of the revised Quality Assurance Requirements and Description document. The preexisting quality assurance program consisted of a sixty page quality assurance program plan, a six hour orientation class, thirty seven quality administrative procedures, a software quality assurance plan and six associated procedures, and a one hour auditor class. By December, 1993, the program was revised to include thirty quality administrative procedures, a four hour orientation class, a two hour records management class, a one hour auditor class, and a requirements traceability network matrix (which is used to show where procedures meet requirements). The new program resulted in a more streamlined training program, simplified forms in procedures, and more efficient record management, software quality assurance, publication, and measuring and test equipment work processes. Other accomplishments include the incorporation of an electronic training database to replace a paper intensive process and a new records management class. The procedure revisions taxed staff capabilities, in that over $\mathbf{5 2 0 0}$ individual comments were addressed in the review of procedures. Personnel submitted 815 records to the DOE with only a very low, respectable $0.5 \%$ rejection. Lastly, the software program now has 128 programs approved for work subject to quality program requirements.
\end{abstract}

The Project Office personnel conducted one audit and two surveys of Los Alamos activities. Los Alamos verification personnel conducted twelve audits and six surveys. Seven DOE corrective action reports were closed. This is the first time since 1987 that there were no open corrective action reports at the end of the year. Internally, seventeen deficiencies were recognized. This continues a favorable trend of decreasing deficiencies since 1990. Audited individuals were knowledgeable and responsive to quality assurance requirements.

Trend reports for 1993 were examined and are summarized herein. One open adverse trend will be closed when the affected software procedures are revised. When the number of corrective action reports issued by the DOE were considered, a decreasing trend in the number of reports issued to Los Alamos is indicated. In fact, Los Alamos personnel have continually reduced the number of corrective action reports issued to them by DOE annually for the last four years. 


\subsection{INTRODUCTION}

This status report is for calendar year 1993. It summarizes the annual activities and accomplishments of the Los Alamos National Laboratory (Los Alamos) Yucca Mountain Site Characterization Project (YMP or Project) quality assurance program (hereafter referred to as the quality program). By identifying the accomplishments of the quality program, we establish a baseline that will assist in decision making, improve administrative controls and predictability, and allow us to annually identify long term trends and to evaluate improvements. This is the third annual status report (Bolivar, 1992; Bolivar, 1994).

Quality issues are discussed at $Q$ meetings. Since many personnel are now more knowledgeable about the YMP and quality issues than they were in 1991, and since many of the major issues have been addressed, we were able to reduce our meeting frequency from bimonthly to about once every quarter. These meetings are supplemented by smaller special process team meetings which are held as needed.

Attendance at $Q$ meetings is mandatory for the contributors of this report. These individuals constitute the $Q$ team. At the beginning of each meeting, members summarize their accomplishments since the last meeting and identify any issues to be addressed. Any YMP personnel may bring any quality issue before the meeting for discussion. Discussions are resolved at the $\mathrm{Q}$ meeting or limited to one hour discussion per issue. If unresolved, the issue is assigned to a special process team. These teams are comprised of a smaller number of individuals who have expertise on the subject matter or who are impacted by the issue. The $Q$ team discussions and consequent guidance, decisions, or philosophies are documented herein.

This report is divided into two primary sections: Program Activities and Trend Analysis. Under Program Activities, programmatic issues occurring in 1993 are discussed. The goals for 1993 (Bolivar, 1994) are also listed, followed by a discussion of their status. Lastly, goals for 1994 are identified. The Trend Analysis section is a summary of 1993 quarterly trend reports and provides a good overview of the quality assurance issues of the Los Alamos YMP.

1.1 Organization. Training, records, and document control activities do not administratively fall under the auspices of the Quality Assurance Project Leader (QAPL). They are discussed herein because these activities are an integral part of the overall quality program, representatives from these activities attend quality meetings, and the QAPL and Administration and Control Project Leader work closely to ensure the needs of the Los Alamos YMP are met. A discussion of the Los Alamos YMP organization is thus included to clarify the responsibilities of these entities.

The Los Alamos YMP quality program consists of four organizations, which are managed by a Deputy Technical Project Officer (TPO) and three Project Leaders: the Test Coordination Office, with Ned Elkins (Deputy TPO) as head; Site and Regulatory Investigations led by Janet MercerSmith; Administration and Control, headed by Allyn Pratt (ACPL); and Quality Assurance, led by Stephen Bolivar. These staff report to the TPO Julie Canepa.

Personnel changes include the addition of Janet Mercer-Smith as the Site and Regulatory Investigations Project Leader (effective November, 1993). In April, Mike Clevenger became Deputy Quality Assurance Project Leader. This position was formerly filled by Paul Gillespie, who took over coordination of the Requirements Traceability Network database. John Day became DOE Liaison, which is a new function. This position should foster better communication with DOE. 
Interactions between technical groups and the quality organization are normally handled by Quality Assurance Liaisons (QALs). Audit, survey and verification functions are administered by a Verification Coordinator, whereas a Software Coordinator handles configuration control of the software program. These positions report to the Quality Assurance Project Leader (Fig. 1).

QAL responsibilities are identified in Table I. During the year, one QAL retired and one left the YMP. Lyle Wichman was hired as a new QAL. The EES-13 QAL duties were assumed by the Deputy QAPL, Mike Clevenger. Because we were able to consolidate duties among existing QALs, manpower needs were reduced by about 0.5 staff. In the last two years QAL manpower needs were reduced by about 1.5 people, even though the scope of work has slightly increased.

Table I. Quality Assurance Liaison (QAL) Responsibilities.

\begin{tabular}{||l|l||}
\hline \multicolumn{1}{|c|}{ Person } & \multicolumn{1}{c|}{ Responsibilities } \\
\hline \hline Andrew Burningham & $\begin{array}{l}\text { Group EES-13/TCO; Group EES-13/LV Volcanism; Subcontractors } \\
\text { University of New Mexico; Ohio State University; University of } \\
\text { California (Riverside); Golder Associates }\end{array}$ \\
\hline Mike Clevenger & Group EES-13; Deficiency Report Coordinator; Deputy QAPL \\
\hline Richard Shay & $\begin{array}{l}\text { INC Division; EES-5; Subcontractors } \\
\text { HydroGeoChem; Lawrence Berkeley Laboratory; Stanford University; } \\
\text { M\&TE Coordinator. }\end{array}$ \\
\hline Lyle Wichman & Groups EES-1, EES-4, EES-15 and LS-2; assists M\&TE Coordinator. \\
\hline
\end{tabular}

Training, Records, and Document Control Coordinators report to the Administration and Control Project Leader (ACPL). So do Resident File Custodians (RFC) who maintain the resident files where quality records are stored. Because the YMP requires dual storage of quality records, the Records Coordinator maintains a Records Processing Center (RPC) where the second set of records is kept. The relationship between the ACPL and these groups is depicted in Figure 1.

In 1993, 142 people were involved in the Los Alamos YMP, although not all are full time equivalents. Of these 142,110 are involved in quality activities, i.e. activities governed by the Quality Assurance Requirements and Description document. Table II shows the Los Alamos YMP personnel categorized by Laboratory group for 1993. 

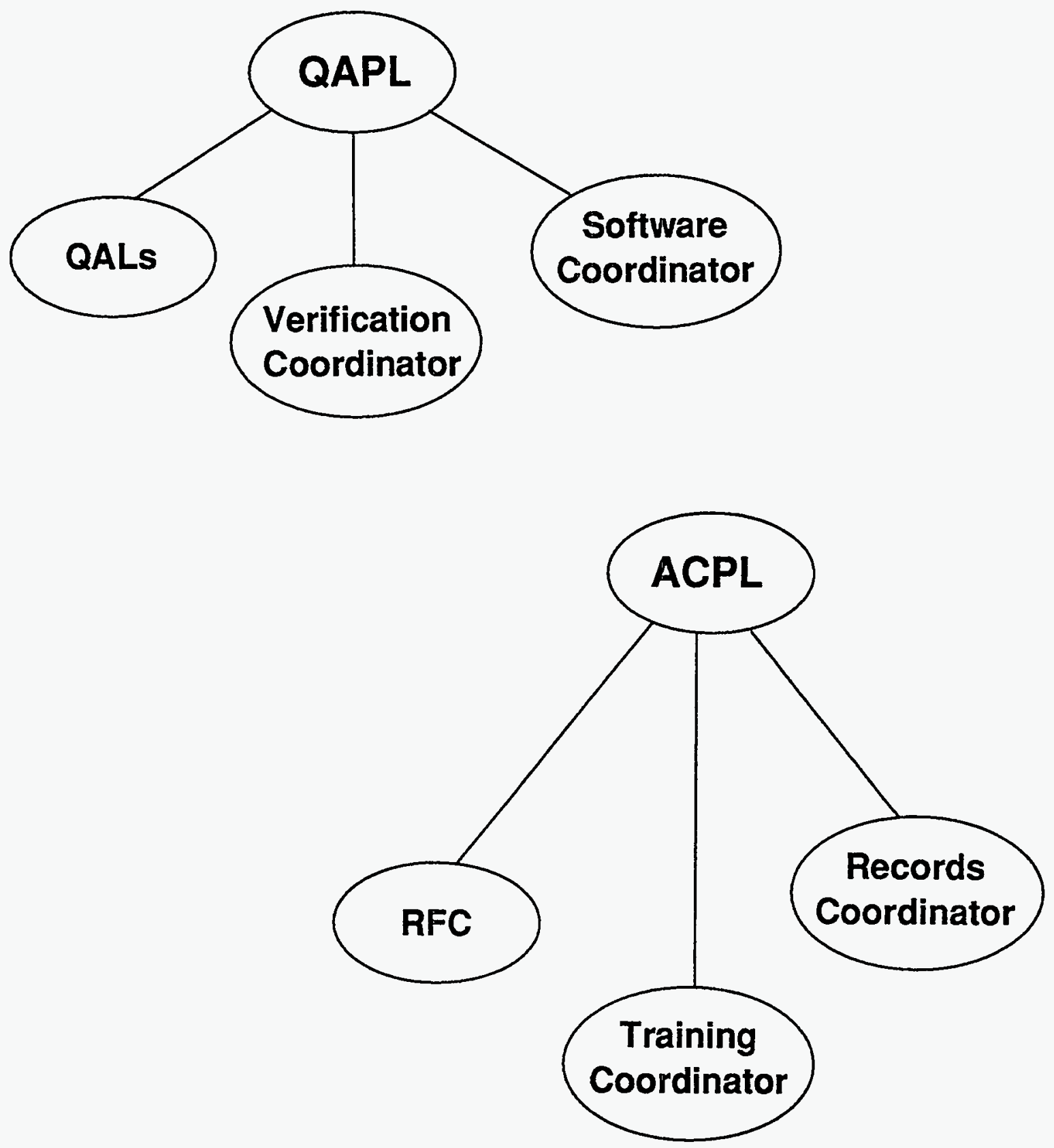

Fig. 1. Organizational Reporting Responsibilities (acronyms described in text). 
Table II. Laboratory Groups and YMP Personnel.

\begin{tabular}{|c|c|c|}
\hline Groups & Q Activity & Non-Q Activity \\
\hline $\begin{array}{l}\text { Earth and Environmental Sciences (EES) Division } \\
\text { (except for program management) }\end{array}$ & 28 & 5 \\
\hline Program Management & 23 & 11 \\
\hline Isotope and Nuclear Chemistry (INC) Division & 22 & 4 \\
\hline Other Divisions & 4 & 3 \\
\hline Contractors & 31 & 9 \\
\hline Totals & 110 & 32 \\
\hline
\end{tabular}

\subsection{PROGRAM ACTIVITIES}

2.1 Program Development. Most program development activities are initiated and discussed in Q meetings. Action items are assigned to individuals, and their status is tracked via an action item database. This database is used to ensure that items are resolved. Action items may cover simple tasks, such as making a phone call, to more involved tasks such as revising a procedure. The status of open items is discussed at each Q meeting. In 1993, 236 action items were addressed.

We are still trying to determine the best frequency for meetings. In 1991, about twenty-five meetings were held. In 1992, the frequency was reduced to about one per month. In 1993, we met about five times. These quarterly meetings are supplemented by smaller special process team meetings. For example, the QALs and QAPL met about once per month. The frequency of one $Q$ meeting per quarter, where major issues are discussed, supplemented by smaller special process team meetings as needed, appears to be an optimum frequency for the $Q$ team.

During the first $Q$ meeting of 1993, a self assessment of the $1992 \mathrm{Q}$ team was conducted. Brainstorming techniques were used to identify major issues in the Los Alamos YMP that the $Q$ team addressed in 1992. These problems were then ranked and the top three identified. The $Q$ team also examined the action item database and identified the top accomplishments. Lastly, goals for 1993 were identified. The results are shown in Table III.

In 1991, the top three issues were: a) lack of accountability for deadlines; b) excessive problems with records; and c) management not involved in $Q$ meetings. We determined that we generally resolved these issues in 1992, but because the goals were not quantitative, it was difficult to determine how successful we were. Consequently, we determined we would quantify our 1993 goals so they could be measured. These are listed in Table III. A Q meeting charter was also developed (Appendix A).

Our Los Alamos program office is establishing a computer network. Much of the infrastructure (such as wiring) was installed in 1993. There were also extensive group discussions concerning the potential uses of such a system. This system should become available in early 1994. 
Table III. Self-Assessment of the $1993 \mathrm{Q}$ Team.

\begin{tabular}{|c|c|}
\hline $\begin{array}{l}\text { Issue Identification } \\
\text { (Top } 3 \text { Issues- what we } \\
\text { spent most of our time on) }\end{array}$ & $\begin{array}{l}\text { 1. Monitoring the revision of procedures } \\
\text { 2. Assessing and updating the training process } \\
\text { 3. Monitoring the verifications of deficiencies }\end{array}$ \\
\hline Acoomplishments & $\begin{array}{l}\text { 1. Communication of YMP business } \\
\text { 2. Team building atmosphere }\end{array}$ \\
\hline Goals for 1993 & $\begin{array}{l}\text { 1. Reduce open internal deficiencies to less than } 10 \text { by } \\
12 / 31 / 94 \\
\text { 2. Develop a } Q \text { team network by } 12 / 31 / 94 \text { so members could } \\
\text { communicate } \\
\text { 3. Decrease our internal records rejection to } 5 \% \\
\text { 4. Implement the QARD by } 7 / 31 / 94 \\
\text { 5. Revise all QPs by } 7 / 31 \\
\text { 6. Hold four Q meeting in } 1994 \\
\text { 7. Identify metrics for problems we address } \\
\text { 8. Hold smaller meetings as necessary }\end{array}$ \\
\hline
\end{tabular}

The Laboratory is experiencing a culture change. Part of this change is an awareness of Continuous Quality Improvement (CQI). The Q team does discuss and try to implement CQI as a normal way of business. This topic is discussed at almost every $Q$ meeting and drives many of our activities.

\subsubsection{Issues.}

The option of using a controlled forms book was again discussed. Currently, the Document Control Coordinator sends forms to selected personnel, usually QALs. We decided not to issue a controlled forms book because most QALs felt this was an administrative task and implementation should be left up to individual groups. It was also decided not to allow people to use the forms directly out of a procedure, because the owner might not have adequate control over the forms. Because each group handles forms differently, and there are no major problems currently, the process will remain as is.

The $Q$ team also examined the process for identifying new and departed employees. At times it has been difficult identifying personnel who work on the YMP. In general, it is the responsibility of the QALs to identify when people join or leave the YMP. This notification is done at the quarterly $Q$ meetings. Thus, changes to distribution lists, the organization chart, and training files documentation are initiated at this time. The QALs agreed to ensure the organization chart titles and position description titles were consistent. We also agreed to place an informal note in personnel files when personnel left. This would allow us to better identify when personnel were active. One QAL was selected to contact departed employees and ask them to fill out a Quality Concerns questionnaire.

In an effort at continuous improvement, Mike Clevenger agreed to take the organization chart and update it so that it would be a better visual aid (the current chart is forty pages thick and difficult 
to use). He was able to reduce the chart to thirteen pages, with major organizations depicted on a single page. The QALs also worked out a process to ensure that position descriptions followed TPO policy and organization titles matched. This information was incorporated into QP-01.4.

Two forms of electronic media affected discussions at several of our $Q$ meetings. One was the development and testing of an electronic version of the training database. This is discussed further under Section 2.4, Training. The other was discussion of the philosophy for an electronic network so that various members of the team would be able to better communicate. Change to an electronic network is favored by the QAPL but has not yet garnered a lot of Q team support. This will be an important issue in 1994.

One Q meeting was held in Las Vegas. DOE management feels it is important for YMP members to see firsthand the Las Vegas operations, and to actually visit Yucca Mountain. Almost all members of the Q team visited the Field Operations Center, the Sample Management Facility, and North Portal of Yucca Mountain. The $Q$ team also attended Conflict Resolution and Root Cause Determination classes, toured the local records center, were oriented to the Test Coordination Office, and critique a pilot class for our QP-17.6. These activities greatly contributed to a better understanding of the YMP, as well as creating better relations between various organizations.

Several miscellaneous items were also discussed. These included developing a method to help investigators obtain faster (and higher quality) copies of notebooks, composing a standard exemption phrase for those investigators who did not want to turn their old notebooks into records as required in a recent revision of procedure QP-03.5, developing guidelines for QALs to submit monthly reports to the QAPL, and QALs agreeing to visit subcontractors once per quarter. Other items are discussed under the appropriate subheadings.

\subsubsection{Goals for 1993.}

- Write a procedure that allows for exemption to administrative procedures.

- Hold quarterly Q meetings in 1993.

- Better define the mission of the $Q$ team.

- Discuss the possibility of forming a QA steering committee.

- Produce a relational database for distribution lists.

A procedure allowing exemption to quality administrative procedures was developed and issued. Five $Q$ meetings were held, and the mission of the $Q$ team was identified in a charter (Appendix A). Although a steering committee was not formed, the $Q$ team was organized such that subteams or smaller process teams could be selected when issues became too complex for the $Q$ team to handle. This approach worked very well. A relational database was not developed because it depends on having a functional network. This will be deferred to 1994 . In all, $80 \%$ of goals were met or exceeded.

\subsubsection{Goals for 1994 .}

- Develop a working network such that $Q$ team members can communicate.

- Produce a relational database for distribution lists.

- QALs to visit subcontractors at least once per quarter. 
2.2 Procedure Revisions. The Los Alamos quality program uses two types of implementing procedures: quality administrative procedures (QPs) and detailed technical procedures (DPs). Preparation follows formal guidelines as described in QPs-06.2 and -06.3. In addition, QPs are edited and formatted by the EES-13 office.

In January 1993, the DOE required that we implement the new Quality Assurance Requirements and Description (QARD). This document contains all quality related requirements. However, to meet these requirements, we would have to revise every quality administrative procedure (QP).

The Los Alamos quality program at the beginning of 1993 had a sixty page quality assurance program plan, thirty-seven QPs, a six hour orientation class, a software quality assurance plan and six corresponding procedures, a formal auditors class, and eighty-two DPs. Table IV shows the status of procedure revisions for the last three years. To revise all our procedures in 1993 would require a tremendous effort, and we wondered if we had the ability to do it. Fortunately, only the QPs (and not the DPs) would have to be revised to meet the QARD requirements.

Table IV. Procedure Revision Status.

\begin{tabular}{||l|c|c|c|c|c|}
\hline 1991 & Total & Affected & New & Delete & Redo \\
\hline \hline QPs & 38 & 25 & 11 & 4 & 10 \\
\hline DPs & 84 & 23 & 4 & 2 & 17 \\
\hline
\end{tabular}

\begin{tabular}{||l|c|c|c|c|c||}
\hline 1992 & Total & Affected & New & Delete & Redo \\
\hline QPs & 36 & 27 & 7 & 7 & 13 \\
\hline DPs & 82 & 47 & 16 & 18 & 13 \\
\hline
\end{tabular}

\begin{tabular}{|l|c|c|c|c|c|}
\hline 1993 & Total & Affected & New & Delete & Redo \\
\hline \hline QPs & 37 & 47 & 10 & 8 & 29 \\
\hline DPs & 90 & 12 & 3 & 2 & 7 \\
\hline
\end{tabular}

\subsubsection{Issues.}

The DOE requested that we submit various transition and impact plans identifying how we would implement the QARD. We discussed various approaches at a $Q$ meeting, but because the problem was so complex, we created an implementation team of four people. They examined various strategies. It was suggested that we

- Redo all procedures simultaneously.

- Initiate an electronic version of the training database. 
- Simplify the records, measuring and test equipment, software, technical information products, and study plan review processes.

- Update the orientation class and develop a new records management class.

- Release all new procedures simultaneously (rather than one at a time)

The new QARD does not require a separate quality assurance program plan document describing the overall quality program. The Los Alamos YMP quality assurance program plan would be described solely by QPs; in particular, our organizational procedure would describe our quality assurance program and would include an overview of the Los Alamos YMP.

The implementation team presented the plan to the $Q$ team. The $Q$ team had been struggling to improve the procedure revision process and reduce the time required to issue a revised procedure. The YMP quality assurance revision process requires mandatory reviews by affected organizations, and this can be a lengthy process. A process improvement exercise in 1992 resulted in shortening the process for completing minor revisions to a couple of months and major revisions to under five months. Although it would be ambitious to revise all procedures, it certainly seemed possible (Table V).

Table V. Statistics for Revision of Procedures.

\begin{tabular}{||l|l|l|c||}
\hline Year & Type of Revision & Time (major/minor) & Percent (of total) Revised \\
\hline 1989 & 4 major/ 0 minor & $18 \mathrm{mo}$ & $10 \%$ \\
\hline 1990 & 5 major/ 4 minor & $18 \mathrm{mo} / 11 \mathrm{mo}$ & $22 \%$ \\
\hline 1991 & 13 major/ 4 minor & $12 \mathrm{mo} / 6 \mathrm{mo}$ & $42 \%$ \\
\hline 1992 & 16 major/ 5 minor & $5 \mathrm{mo} / 2 \mathrm{mo}$ & $53 \%$ \\
\hline 1993 & 23 major/ 15 minor & $8.7 \mathrm{mo} / 4.5 \mathrm{mo}$ & $100 \%$ \\
\hline
\end{tabular}

We believed the revision of all procedures would provide an opportunity to improve the various processes. We had recently employed a new software coordinator, and thus this would also be a good opportunity to improve the software process. Lastly, the $Q$ team had been discussing the introduction of an electronic database for training and had been laying the groundwork to initiate such a move over the last several months. Because we were required to annually update the orientation class and wanted to introduce a new records management class, these activities could also be integrated. Our biggest concern was, would our personnel be able to handle revising all procedures, develop a couple of classes, and improve several processes all at once? For many people, procedure revisions would be a task done in addition to their normal duties.

We used the concept that procedures should be "stand-alone" as much as possible. Review forms should be available for each procedure, rather than directing the reader to use the form in another QP. This reduces the confusion of having to train to a procedure when one only uses the review forms from that procedure. Second, forms were redesigned to be self explanatory.

The DOE was notified of our transition plan (we initially expected to be finished by August), and 
authors were selected. The QAPL felt that the revisions to meet the new QARD would be relatively straightforward and easy. We had expected some personnel departures and had foreseen some hardware and software problems. As a result of our planning, these transitions were made relatively smoothly. However, the magnitude of expected problems as well as several unanticipated problems resulted in stressful times. Part of the turmoil was that everyone was simply trying to complete primary duties in addition to revising procedures.

Some of the problems encountered were

- Review process became more complex than anticipated.

- Formatting and consistency were much larger magnitude than anticipated.

- Electronic connections were difficult to get working.

- Personnel changed projects.

- Some processes were more difficult than initially envisioned.

- Some software and hardware incompatibilities were difficult to solve.

- Unanticipated administrative bottlenecks occurred.

These problems are described at length by Bolivar, 1994. They are briefly described below.

Initially, revised procedures were submitted to a member of the implementation team, who reviewed the initial draft. Some revisions cycled through this step several times. New or complex procedures were formally edited, and the QAPL reviewed all QPs before they were released for formal YMP review.

The YMP quality assurance requirements require procedures to be reviewed by affected organizations. If procedure reviews cause extensive changes to the process, the procedure has to be put into the formal review cycle again. We found one method of accelerating reviews was to provide affected organizations with preliminary copies. Major changes would then be incorporated before a procedure was released for formal review. Another successful method was to hold a comment resolution meeting. Differences of opinion could usually be resolved in a timely manner.

Surprisingly, we had over 200 formal YMP reviews and 150 informal reviews. This resulted in over 5200 individual comments. Each comment had to be resolved, and this took longer than anticipated.

As a matter of protocol, the final formatted version of a procedure was completed in the Los Alamos YMP office. Unfortunately, we were using one software program for the text and another for the forms. The forms could only be created by one person on one machine, and at times this created a bottleneck. The software procedures were on yet another system. Many procedures were keyed in more than once because of hardware incompatibilities between the program office and the authors' systems. When we felt we had control of the system, the hard disc crashed. Our solution was to limit word processing to one person. Occasionally the word processor became overloaded, in part due to conflicting priorities (the word processor also had other office duties to complete). Although this did create a bottleneck at times, it did provide consistency. To simplify the process, we committed to placing all text in one word processing system.

We originally expected to find some inconsistencies as we reviewed QPs. However, the magnitude of the changes was truly a headache. For example, if a format change that improved a procedure was agreed upon, procedures that had already been approved would have to be reexamined. This was particularly a problem with references, which would change every time a procedure was revised.

The DOE required that the procedures be entered into the requirements traceability network 
(RTN). The RTN will allow one to identify what procedures are affected when a requirement is revised. Unfortunately, we had connection difficulties and were unable to utilize the electronic system until October.

We had been planning to develop a records management class for several months, and the revision of all procedures provided an opportune time to initiate this activity. We had hoped to couple the development of this class with the annual revision of the orientation class. Unfortunately these activities took twice as long as we planned. Both classes were affected by the several iterations that the records procedure went through. Our records procedure in turn was affected by DOE changes in their records procedure and records training plan.

Four procedures were completed before it became obvious they were not needed. This was because as more and more procedures neared completion, several processes became better defined, and we realized that some activities belonged elsewhere. In some cases, we found we did not understand a process very well, and in other cases we realized the process we had been using should be changed. These realizations led to completely rewriting the records management and measuring and test equipment procedures. On a more positive note, we were able to combine ten procedures into six, and delete nine others.

By encountering increased work loads, we were forced to become more efficient. Our first procedure was revised four times before the editor said "enough," and we went with what we had. We realized that the former revision process, which was adequate if we only revised a few procedures a year, could be more efficiently run. For example, one way to speed up reviews was to hold a comment resolution meeting. We were able to get all procedures onto one processing system, and individuals were cross trained to avoid bottlenecks. It became obvious that some processes that we had not anticipated changing had to be modified, the new regulations had impacts that no one could predict, and the revision process had to be iterative and thus took longer than planned. It was necessary in some instances to get clarifications from DOE on interpretation of requirements. By December 23, 1993, all QPs had been revised, and the new classes were prepared.

Procedure revisions were the major business item at $Q$ meetings. The revisions resulted in a more streamlined training program, fewer forms in procedures, and more efficient work processes. Changes included developing an organizational procedure with a YMP overview and policy statement, combining the records system procedures QPs-17.4 and -17.5, combining procurement procedures QP-04.4 and -04.5, and replacing two deficiency reporting procedures with a new Corrective Action Report procedure. A RTN process procedure and a grading procedure (now called exemptions) were developed; the personnel selection, training, and orientation procedures were combined from five into three procedures; TCO procedures were reduced from three to two; the traveler in QP-03.23 was simplified as was the publication process; the software procedures were revised to incorporate the requirements from the software quality assurance plan; and better guidance on how to control supplier manuals and their updates was added to the procedure for measuring and test equipment. This last procedure was also greatly simplified. We started with thirty-seven QPs and now have thirty. There is $22 \%$ less paper, and $7 \%$ fewer forms. Lastly, since most of our processes have been relatively well defined and majority of procedures formally reviewed by an editor, we were able to eliminate the QP editor position. Procedures still get edited, but it is no longer necessary to maintain a full-time editor to fulfill this need.

\subsubsection{Goals for 1993.}

- Write an organization procedure.

- Revise all QPs to meet the new QARD requirements. 
- Withdraw the quality assurance program plan.

An organization procedure (QP-01.4) was written and the appropriate QPs revised. The quality assurance program plan is now described in the organizational procedure. These goals were $80 \%$ realized.

\subsubsection{Goals for 1994 .}

- Look at the QP revision process and determine if it can be made more efficient.

- Revise selected QPs to satisfy any DOE review comments.

- Withdraw the quality assurance program plan.

2.3 Measuring and Test Equipment (M\&TE). These activities are administratively handled by an M\&TE Coordinator. The M\&TE Coordinator notifies individuals when calibrations are due.

\subsubsection{Issues.}

The M\&TE procedure needed revision as the result of new QARD requirements; thus we used this opportunity to completely rewrite the procedure. There was extensive discussion on whether we needed a separate procedure for standards or if it should be combined with the M\&TE procedure. We decided to keep just one procedure; however, separate forms are used for standards versus M\&TE equipment. This procedure elicited several comments from investigators. As the result of these discussions, the procedure better reflects how the process works.

We formerly required anyone who used equipment to train to the M\&TE procedure. However, the procedure is only used by those who do actual calibrations; therefore it was suggested that we limit training only to those who do calibrations. The text was also revised to bring procedures more in line with Laboratory M\&TE policies.

\subsubsection{Goals for 1993 .}

- Revise the M\&TE procedure (QP-12.1).

- Examine and streamline the M\&TE process.

Both of these goals were met for a $100 \%$ completion rate; however, the process can still be sreamlined further.

\subsubsection{Goal for 1994 .}

- Examine QP-12.3 and determine if the process can be further simplified.

2.4 Training. The Los Alamos quality program philosophy is that documented training is only required for individual performing work governed by the QARD. We have always invoked a paper intensive process to track training. During several discussions, members of the $Q$ team realized 
that we needed to have a better system, preferably an electronic one. It was also believed that a formal training class on our records procedure could alleviate some of the errors we were having with record package submissions. Although the issuance of the QARD required that we revise our training procedures, it also provided us with an opportunity to change to an electronic tracking system.

At the beginning of 1993, we had formal training for YMP Orientation (six hours), auditors (one hour), and the software development process (eight hours). The general consensus of the $Q$ team was that we should examine the need for formal training classes (Appendix B). Classroom status is shown in Table VI. Survey comments suggested that the software class, although on video, was not very effective. The Orientation class was updated and taught to twenty-three people on February 25, 1993 (LATA, 1994a,b). Over 95\% of all comments for the last two years have been positive, although there have been suggestions to shorten the class. Based on the frequency of problems with record packages, which are associated with failure to pay attention to detail problems, there does appear to be a strong need for records training.

We are also gradually transferring from formal classroom training to "read only" training. There is no noticeable correlation between records rejected (discussed under Section 2.6), deficiencies (see Trend Analysis, Section 3.0), and number of classes taught (Table VI).

Our electronic training database was much more difficult to develop and implement than we imagined. Part of this delay was caused by "bells and whistles" we wanted to add, and part was the normal problems encountered when changing from a paper intensive process to an electronic one. This process took almost twice as long as we had envisioned (Environmental Safety Services, 1993).

Table VI. Training Classes.

\begin{tabular}{|c|c|c|}
\hline Year & Classes Held & Attendees \\
\hline 1991 & 52 & 247 \\
\hline 1992 & 16 & 125 \\
\hline 1993 & 3 & 41 \\
\hline
\end{tabular}

\subsubsection{Issues.}

During several discussions throughout the year, we addressed how we could make our training program more effective. We determined that only the Orientation class would be mandatory for all YMP employees. We were determined to create a new training class for records. Rather than create separate classes for several procedures, it appears that one class for all of criterion three might be feasible. This class would address a process, rather than be directed to specific procedural requirements. However, based on the workload for 1993, development of this class would have to be delayed until at least 1995 . We also discussed the possibility of creating another video which would track the life of a record, but this also would have to be delayed until 1995.

It was decided that a computerized training database would be designed for the Training Coordinator. It would allow for automatic notification of training as procedures are revised. This 
would greatly reduce duplication of efforts between the Training Coordinator and QALs. Efforts to design this system began in November, 1992. The efforts continued throughout most of 1993. A program was available for testing at the end of December. Much of the development time was put into making the program relatively easy to use.

All three training procedures were revised in 1993. The issue of proficiency evaluations was discussed at length by the $Q$ team and a special process team. It was determined that proficiency evaluations are not required by the QARD. Since our supervisors actually do a proficiency evaluation every time a training class notice is distributed, we have no need for QP-02.9. Therefore, we decided to combine this QP with QP-02.5 (Selection of Personnel ) and QP-02.7 (Personnel Training). When the new training classes were completed, we found that we had reduced our classroom hours from fifteen to seven (this does not include DP training).

The Limited Function process was also slightly modified. A step was added that provided for verification of the Limited Function person's credentials. This process has been used in the past to primarily provide relief to training requirements. The new step simply gives the process more credibility. Lastly, we also decided that training is only required for the applicable sessions in a $\mathrm{QP}$ - i.e., rather than train to a QP, one only needs to train to the applicable sections.

The majority of training development went into designing and testing the new records management training class. Our training specialist conducted a survey and met with the QAPL to best determine training objectives. The QAPL was adamant that the training class be activity oriented with a minimum of lecture.

The training specialist conducted a survey. The survey revealed the issues that had to be addressed were

- Most people do not understand the records process.

- It is not clear which records go in the system.

- There is a lack of attention to detail.

- Responsibility for records has to be made clear.

- Define what is/is not a record.

- Where does one go for information.

- Identify the most common mistakes.

- Have consequences for failure to comply.

- Identify quality assurance and non quality assurance records.

The survey also revealed that the most acceptable methods for conveying this information would be "hands-on training". There also was a clear mandate to provide a proficiency test option. Two important issues that had to be addressed in the class activities were antitraining attitudes and unwillingness to accept responsibility. Over a period of several months a class addressing the above issues was developed.

Two pilot classes were held; one in May at the Test Coordination Office (TCO) in Las Vegas, and one in September at Lawrence Berkeley Laboratory (LBL). The TCO class revealed that there were too many handouts. The manual was streamlined and handouts reduced by $60 \%$. The number of activities were also reduced by $50 \%$. For the LBL class, the amount of lecture time still had to be reduced, but the length of activities was satisfactory. The $Q$ team had several discussions about who the customer of the class should be. It was decided the class would be designed for experienced employees, those who had been on the YMP for several months. 


\subsubsection{Goals for 1993.}

- Revise QPs -02.5, -02.7 \& -02.9.

- Set up an electronic training database.

- Determine if we need a "Train the Trainers" class.

All three goals were accomplished. After discussion with DOE personnel, the training class became a non issue because at Los Alamos a subject matter expert is always the instructor. A lesson plan would be developed and documented so that no matter who taught the class, the same information would be taught. All goals were exceeded or completed for a $100 \%$ completion rate.

\subsubsection{Goals for 1994.}

- Test the training database and fix all problems.

- Complete the 17.6 class and offer it to all YMP personnel.

- Ensure that the Orientation class reflects any changes in procedures or requirements.

- Decide what, if any, training is needed for 1995.

2.5 Software. Requests to accept or modify software packages are submitted via a software change request form. These are evaluated by a Configuration Control Board (CCB), and after selected documents are produced and reviews conducted, a software package can be accepted. The status of software change requests is shown in Table VII. A software management status report is included as Appendix C. It appears that the majority of affected software has been at least entered into the system.

Richard Morley started the year as Software Management Coordinator. He was replaced by Christ Mechels in April. Bruce Robinson remained as software Configuration Control Board Chairman. A technician assistant position was selected to be phased out after the software procedures were revised, probably by early 1994 . In 1993, four CCB meetings were held.

Table VII. Status of Software Change Requests.

\begin{tabular}{|c|c|c|}
\hline Year & Submitted & Approved \\
\hline 1991 & 131 & 49 \\
\hline 1992 & 38 & 66 \\
\hline 1993 & 12 & 13 \\
\hline Totals & 181 & 128 \\
\hline
\end{tabular}

\subsubsection{Issues.}

This has been a very busy year for software personnel. In January we inventoried the hardware and software for the variety or computers and workstations used on the YMP. The architecture 
was described and flow chartered. This allowed us to identify what we had and to better determine future needs.

At the beginning of 1993, the software program consisted of six QPs with a software quality assurance plan, and an extensive eight hour video training. The new QARD requirements required that we revise all these documents. Because the new QARD greatly reduced the types of software that have to be controlled, it was decided that the software quality assurance plan (formerly an implementing document) could be incorporated into the six software QPs, and thus eliminated. In turn, the six QPs could be reduced into four QPs. We would then supplement these four QPs with a software quality assurance guidebook, which would not contain any requirements, only guidance. We found that our QPs also had to be revised to better reflect how we do work. The former QPs were not always followed to the letter. A stop work order against computational data procedure was also addressed. We also found that the video training was not very effective and eliminated this training requirement. A possible new training process may be considered at some future date, but we do not have enough affected people to justify directing training funds to this area presently.

Our software program is in a state of change. The exact direction will depend on what DOE and the Nuclear Regulatory Commission (NRC) want from us. Although the most recent QARD resulted in a lessening of former software requirements, some feel that the requirements may change again, becoming more strict. Change seems imminent based on the recognition of DOE orders and the fact that only scientific and engineering software (SES) is addressed currently in the QARD. Thus our QP revision tried to maintain a capability to allow for a stricter program should the need arise. However, the current software Management Coordinator is looking for more efficient ways to conduct software engineering and configuration control.

\subsubsection{Goals for 1993 .}

- Revise the SQAP and associated QPs.

- Examine the software training requirements.

- Hire a permanent software configuration control manager.

- Set up a local area network.

All software procedures were revised and the formal training requirements changed to "read only". A permanent Software Management Coordinator was hired in April. The network was started and should be up and working in early 1994 . Over $90 \%$ of the goals were met.

\subsubsection{Goals for 1994 .}

- Examine the new process and ensure that it functions adequately.

- Determine if formal training is needed for the software QPs.

- Determine if better software engineering and configuration control methodology could be used.

- Set up a local area network.

2.6 Records. Lynn Sanders returned to fill the Records Coordinator position. This position was redefined to allow for more focus more on liaisons between DOE and Los Alamos. In the middle of the year this position again became vacant. The day to day operations were redefined and Sandy Martinez was selected as Records Processing Coordinator. John Day was selected as Project Office Liaison and will focus his efforts on records, training, and quality assurance issues. In August, Alice Thompson, from the TCO, was selected as Deputy Records Processing Coordinator. These 
selections simplified the records functions and worked well for the remainder of the year.

In 1992, 971 records were received by the Records Processing Center. Of these, 117 (12\%) were rejected internally. After the records were fixed, they were submitted to the Central Records Center in Nevada. Of the 971 submitted, thirty-seven were rejected (3.8\%). In 1993 the total number of records submitted was 816 , a decrease of $16 \%$. The RPC rejection rate remained about the same. The $Q$ team felt that a proper records management class could help reduce the internal rejection rate. On a very positive note, the DOE 1993 rejection rate was reduced to $0.5 \%$. This is an excellent acceptance level.

The records process was discussed at length at every $Q$ meeting. Gradually, we began to better understand the role of the Resident File Custodian. The end result was that the procedure was revised and the record submittal form greatly simplified. The complexity of both our system and the DOE process surprised everyone. Although we were able to simplify the process, we can still further improve our efficiency.

\subsubsection{Issues.}

One of the most important issues we faced in 1993 was the possible reduction of funds for record activities. We were able to negotiate with $\mathrm{DOE}$ and maintain an acceptable level of support. In Table VIII, the number of submitted records was reduced by $16 \%$. This is a misleading indicator because although the number of submitted records is less, the actual number of pages is more. Thus we have started tracking number of pages submitted.

About 75\% of our records come from our project office and the Las Vegas operations (TCO). In 1993, the amount of records from technical groups EES-1 and INC also increased. Unfortunately, internal rejection rates for 1993 and 1992 are similar. Because of this, and because the Q team feels the 12 to $13 \%$ rejection rate is too high, the records management formal training class was designed. Although the rejection of records is one of our most visible problems, only about $0.5 \%$ of the records sent to the Project Office are rejected. This rejection rates is one of the lowest in the YMP.

The reasons for rejected records are complex and vary from group to group. Issues such as lack of training, changing terminology, inconsistent application of regulations, lack of attention to detail, a complicated record management plan that is not a requirement document in the eyes of quality assurance but is in the eyes of DOE records personnel, and some requirements that are not reasonable nor understood by investigators (such as requiring black ink on all quality documents), all contribute to the problem.

Many investigators are not adequately trained in records terminology, or they expect other personnel (such as resident file custodians) to perform a review of records before they are submitted. The final responsibility for a record rests with the originator, and this concept is not fully understood nor practiced by all investigators. Thus, we committed to "hands on" mandatory training class. The foundation for this class was developed early in 1992 but was put on hold when the Records Coordinator left the Project and budget restrictions limited our training development.

In early 1993, our records personnel felt that Group EES-13 personnel were submitting records with an unacceptable number of errors. Some $Q$ team members even suggested that the resident file custodian position be eliminated because it appeared to be contributing to the problem. A special process team studied the EES-13 submittal process. Records submitted by this group seldom received any review. The team suggested that a dedicated person be assigned to review 
Table VIII. Records Statistics for 1992 (top) and 1993 (bottom) .

\begin{tabular}{|l|l|l|l||}
\hline Group & $\begin{array}{l}\text { Records Submitted } \\
\text { (with \% of total) }\end{array}$ & $\begin{array}{l}\text { RPC } \\
\text { Reject }\end{array}$ & YMP Reject \\
\hline EES-13 & $628(64.7 \%)$ & 69 & 21 \\
\hline EES-13-LV & $214(22 \%)$ & 8 & 3 \\
\hline EES-1 & $54(5.6 \%)$ & 21 & 6 \\
\hline EES-4 & $1(.0001 \%)$ & 1 & 0 \\
\hline EES-5 & $3(0.3 \%)$ & 1 & 2 \\
\hline EES-15 & $4(4.1 \%)$ & 1 & 0 \\
\hline INC & $56(5.8 \%)$ & 14 & 4 \\
\hline LS-2 & $1(.001 \%)$ & 1 & 0 \\
\hline LBL & $10(1.0 \%)$ & 1 & 0 \\
\hline Total & 971 & $117(12 \%)$ & $37(3.8 \%)$ \\
\hline
\end{tabular}

\begin{tabular}{||l|l|l|l||}
\hline \multicolumn{1}{|c|}{ Group } & $\begin{array}{l}\text { Records Submitted } \\
\text { (with \% of total) }\end{array}$ & $\begin{array}{l}\text { RPC } \\
\text { Reject }\end{array}$ & YMP Reject \\
\hline EES-13 & $451(\%)$ & 32 & 0 \\
\hline EES-13-LV & $167(\%)$ & 1 & 1 \\
\hline EES-1 & $68(\%)$ & 27 & 2 \\
\hline EES-4 & $6(\%)$ & 0 & 0 \\
\hline EES-5 & $2(\%)$ & 0 & 0 \\
\hline EES-15 & $10(\%)$ & 8 & 0 \\
\hline INC & $80(\%)$ & 29 & 1 \\
\hline LS-2 & $01(00 \%)$ & 0 & 0 \\
\hline LBL & $31(\%)$ & 4 & 0 \\
\hline Total & 815 & $107(13 \%)$ & $4(0.5 \%)$ \\
\hline
\end{tabular}

EES-13 records. As a result, a part time resident file custodian was hired in mid 1993 by EES-13.

This person received on the job training with the Records Operation Coordinator. The records submitted by EES-13 now have fewer errors. The special process team also examined how records 
were submitted by other groups. Although some groups had problems submitting records, it did not appear to be the fault of the resident file custodian, but rather the fault of the record originator. The originator failed to follow the QP, or failed to review the package before it was submitted. This would be addressed in the formal records management class. Thus, the $Q$ team decided to retain the resident file custodian position.

The special process team also looked at the issue of putting a unique identifier on every page when a records package was submitted. Although this may be a good idea in some cases, it did not seem reasonable to require this for all record packages. This was a critical issue since our records budget was being reduced, and the DOE QA department does not specifically require such.

Another issue was to see if it was reasonable for originators to submit records directly to Las Vegas. It did not appear reasonable to the $Q$ team to have DOE personnel deal with multiple submittors; rather, by coordinating submittals through the local Los Alamos records center we would ensure consistency and facilitate efficiency.

We also agreed to eliminate the traditional TWS number and replace it by a LA number the next time the records procedure is revised. This would facilitate record searches and simplify the nomenclature. To enhance record retrievals, a new microfilm reader was purchased.

In the beginning of the year the DOE requested we reduce our records budget. As a result, we had to identify several areas that we could cut back on. DOE was given a selection. The bottom line was that as money decreased, the amount of services our records personnel provided also reduced. We are trying to make our process more efficient but the constantly changing records requirements makes this very difficult.

One area that was affected by the reduced budget was that of accession numbers. This became a problem when several (over 50) numbers were requested. The computerized system failed to provide a very fast turnaround and we ended up with a bottleneck. We formed a special process team that redefined the accession number process. These changes were then incorporated into our revised records management procedure. The bottom line is that only final reports (defined as LAMS reports) will now have accession numbers. Affected investigations were also notified and advised on how they could speed up the process and avoid potential pitfalls. Our Project Office Liaison agreed to bring this issue up with DOE records personnel and determine what requirement is really driving accession numbers.

The revised QP on records management combined two procedures (QP-17.4 and -17.5) into one procedure (QP-17.6). Although this QP is an improvement over the previous records procedures, the records process is very complex and still difficult to follow in part. The current process can probably be improved and will be examined again in 1994.

\subsubsection{Goals for 1993.}

- Hire a Records Coordinator.

- Examine the records process, and revise the QPs as appropriate.

- Provide a records training class.

- Purchase a new microfilm reader/printer.

- Examine index and tracking system and improve as appropriate.

- Review existing microfilm process.

A Records Coordinator was hired. This position was eventually integrated into that of Records 
Operation Coordinator and Project Office Liaison. The records process was examined and the affected QP revised; the records training class has been developed and will be taught in 1994; and a new microfilm reader was purchased. During the records process examination, the tracking system was discussed. Changes to this system will be postponed until DOE identifies the hardware they will require us to use. This will be delayed to 1994 or 1995. The actual microfilm process is the responsibility of DOE. Over $90 \%$ of the goals were realized.

\subsubsection{Goals for 1994 .}

- Do an in-depth study of the records process.

- Get the Project Office Liaison more involved with DOE on records issues.

- Conduct the new 17.6 class.

- Examine index and tracking system and improve as appropriate.

2.7 Controlled Documents. The majority of controlled documents issued in 1992 were QPs and DPs (Appendix D). The Controlled Document Coordinator continues to change all controlled documents to paper with the red "controlled" marking; the majority of existing documents have been changed.

\subsubsection{Issues.}

The controlled document system works very smoothly and there were not many associated issues. We are examining the possibility of making this system more electronic and have developed various pieces of tracking software that will eventually need to be integrated into a project-wide system.

\subsubsection{Goal for 1993 .}

- Develop a more efficient tracking system.

A better tracking system was developed. $100 \%$ of goals were obtained.

\subsubsection{Goal for 1994 .}

- Determine if the training and controlled document databases can be electronically linked.

2.8 Travel, Presentations, and Publications. Quality organization representatives attend Project Office meetings, workshops, training classes and provide presentations as required. For example, the QAPL and Verification Coordinator attends DOE quarterly quality assurance committee meetings. These meetings provide a forum to discuss quality issues and are an excellent arena to review proposed changes to a quality program.

Meetings attended are listed in Table IX; training classes attended and presentations are listed in Tables X and XI, respectively. Publications are found in References, Section 5.0. These include one conference article (Bolivar and Day, 1993), a management assessment report (Reese, 1993), and the 1992 Status Report (Bolivar, 1994). 


\subsubsection{Goal for 1993.}

- The goal for 1993 is to publish one professional paper on some aspect of the quality program.

This goal was $100 \%$ completed.

\subsubsection{Goals for 1994 .}

- Publish one professional paper on some aspect of the quality program.

- Complete the 1994 status report before the end of 1994.

2.9 Internal Audits and Surveys. Los Alamos YMP internal audits and surveys are coordinated by the Verification Coordinator. In addition to a team of professional auditors, QALs and technical personnel may be used as technical auditors. The Los Alamos YMP currently has five certified lead auditors.

Cleoves Martinez took over as Verification Coordinator over in July. Tim Ickes was hired as an auditor in November. The DOE required that we treat nonconforming samples according to the guidance in criterion fifteen in the QARD. Rather than write a procedure to do this, we agreed to follow their procedure, and Mike Clevenger was selected as Nonconformance Report Coordinator.

The procedures for audits, surveys, and certification of lead auditors were revised. Essentially, no major changes were made.

Table XII shows the 1993 Los Alamos internal audit schedule. All groups, including subcontractors, showed improvements in attitude and awareness of quality issues. Six surveys were conducted to address specific issues of concern or to qualify vendors (Table XIII). Contractors were audited at about the same time as the respective Principal Investigator. This provided a good vertical slice of activities being conducted and proved to be a very effective method of auditing. In November, the number of open deficiency reports fell below twenty. This is the first time the number of open deficiencies was below twenty since the deficiency reporting program started three years ago.

A management assessment was conducted (Reese, 1993). The assessment team suggested that the TPO and QAPL meet more frequently, that a baseline audit be conducted of the new QPs to ensure they conform to the QARD, clarify the Limited Function concept with respect to training, and consolidate and dual store the deficiency report database. These suggestions were all incorporated. There were no deficiencies identified. 
Table IX Meetings.

\begin{tabular}{|c|c|c|}
\hline Meetings & Attendees & Date \\
\hline $\begin{array}{l}\text { Project QA Committee Meeting, } \\
\text { Las Vegas, NV }\end{array}$ & S. Bolivar, J. Day & April \\
\hline $\begin{array}{l}\text { ASQC, Section Meeting, } \\
\text { Albuquerque, NM }\end{array}$ & $\begin{array}{l}\text { S. Bolivar, J. Day } \\
\text { P. Gillespie }\end{array}$ & Feb. \\
\hline $\begin{array}{l}\text { Training Representatives Meeting, } \\
\text { Las Vegas, NV; Golden, CO; } \\
\text { Seattle, WA. }\end{array}$ & C. Chavez, S. Martinez & $\begin{array}{l}\text { Feb. } \\
\text { Sept. }\end{array}$ \\
\hline $\begin{array}{l}\text { Records Representatives Meeting, } \\
\text { Las Vegas, NV }\end{array}$ & S. Martinez & $\begin{array}{l}\text { Jan. } \\
\text { Mar. } \\
\text { April } \\
\text { July }\end{array}$ \\
\hline $\begin{array}{l}\text { Tech. Integration \& Methodology } \\
\text { Analysis, Las Vegas, NV }\end{array}$ & L. Sanders & Feb. \\
\hline $\begin{array}{l}\text { Inform. Resources Management } \\
\text { Council, Las Vegas, NV }\end{array}$ & L. Sanders, C. Mechels & April \\
\hline $\begin{array}{l}\text { Technical Data Meeting, } \\
\text { Las Vegas, NV }\end{array}$ & P. Gillespie, D. Williams & May \\
\hline SQA Conference, Las Vegas, NV & C. Mechels & Nov. \\
\hline $\begin{array}{l}\text { Total Quality Forum Workshop, } \\
\text { Albuquerque, NM }\end{array}$ & S. Bolivar & Feb. \\
\hline $\begin{array}{l}\text { International High-level } \\
\text { Radioactive Waste Management } \\
\text { Conference, Las Vegas, NV }\end{array}$ & $\begin{array}{l}\text { S. Bolivar, P. Gillespie } \\
\text { D. Williams }\end{array}$ & April \\
\hline $\begin{array}{l}\text { American Society for Quality } \\
\text { Control, Las Vegas, NV }\end{array}$ & S. Bolivar & May \\
\hline $\begin{array}{l}\text { ASQC 20th Annual Nat. Energy \& } \\
\text { Environ. Quality Div. Conf., } \\
\text { Indian Wells, CA }\end{array}$ & $\begin{array}{l}\text { S. Bolivar, J. Day } \\
\text { P. Gillespie }\end{array}$ & Sept. \\
\hline
\end{tabular}


Table X. Training.

\begin{tabular}{||l|l|l||}
\hline \multicolumn{1}{|c|}{ Training } & \multicolumn{1}{|c|}{ Attendees } & \multicolumn{1}{c|}{ Date } \\
\hline $\begin{array}{l}\text { Requirements Traceability Network Training (Las } \\
\text { Vegas, NV) }\end{array}$ & S. Bolivar, P. Gillespie & $\begin{array}{l}\text { Jan. } \\
\text { May }\end{array}$ \\
\hline $\begin{array}{l}\text { Conflict Resolution Class } \\
\text { Las Vegas, NV) }\end{array}$ & $\begin{array}{l}\text { S. Bolivar, P. Gillespie, J. Day } \\
\text { (Q team attended May class) }\end{array}$ & $\begin{array}{l}\text { Feb. } \\
\text { May }\end{array}$ \\
\hline Root Cause Determination, Las Vegas, NV & Q team attended & May \\
\hline $\begin{array}{l}\text { Systems and Network Management class, San } \\
\text { Diego, CA }\end{array}$ & R. Morley, M. Robinson & April \\
\hline Rocky Mountain Quality Conference, Denver, CO & S. Bolivar and J. Day & June \\
\hline 4th Dimension Database Class, San Diego, CA & M. Robinson & Nov. \\
\hline $\begin{array}{l}\text { Building a SQA Program for Nuclear Power } \\
\text { Industry class, Albuquerque, NM }\end{array}$ & C. Mechels & Nov. \\
\hline SE/SQA Workshop, Greenbelt, MD & C. Mechels & Dec. \\
\hline $\begin{array}{l}\text { Negotiation \& Conflict Management Course, Los } \\
\text { Alamos, NM }\end{array}$ & S. Bolivar & Dec. \\
\hline RIDs Seminar, Las Vegas, NV & S. Martinez, J. Day & July \\
\hline Performance-Based Training, Golden, CO & S. Martinez, C. Chavez & Sept. \\
\hline QIG Self Assessment Workshop, Knoxville, TN & S. Bolivar & May \\
\hline \hline
\end{tabular}

Table XI. Presentations.

\begin{tabular}{||l|l|l||}
\hline \multicolumn{1}{|c|}{ Presentations } & \multicolumn{1}{c|}{ Presenter } & \multicolumn{1}{c|}{ Date } \\
\hline Status of QA Program, to TCO, Las Vegas, NV & S. Bolivar & $03 / 10 / 93$ \\
\hline The Los Alamos QA Program, to DOE Audit Team & S. Bolivar & $05 / 24 / 93$ \\
\hline Heads or Tails, to Annual YMP Meeting & S. Bolivar & $02 / 26 / 93$ \\
\hline Annual QA Update, to UNM personnel & M. Clevenger & $06 / 23 / 93$ \\
\hline Orientation for QA Program & S. Bolivar & $02 / 25 / 93$ \\
\hline $\begin{array}{l}\text { The Quality Liaison: Combined Technical and Q } \\
\text { Assurance support }\end{array}$ & S. Bolivar and J. Day & $06 / 08 / 93$ \\
\hline Annual QA Update, to LBL personnel & S. Bolivar & $09 / 13 / 93$ \\
\hline $\begin{array}{l}\text { Status of the QA Program, Presentation to All Hands } \\
\text { Meeting }\end{array}$ & S. Bolivar & $11 / 09 / 93$ \\
\hline
\end{tabular}




\subsubsection{Issues.}

Subcontractors sometimes feel they are not an important part of the Los Alamos YMP. This perception is primarily the result of being physically distant from Los Alamos and not being involved in Los Alamos YMP daily activities. To foster better interactions, the QAPL attended several of the subcontractor preaudit meetings and provided presentations on the status of the Los Alamos YMP quality program and on how to be audited. To further enhance communications, the QALs agreed to visit the subcontractors at least once per quarter.

After several audits, the question was raised as to how many deficiency reports should be written when a group has several deficiencies. In other words, should one deficiency report be written to cover all deficiencies, or should one deficiency report be written for every deficiency. It was agreed that one deficiency report would be issued for all deficiencies covered under one procedure. If two deficiencies covered two separate procedures, then two deficiency reports would be issued.

The QAPL and Verification Coordinator met early in 1993 and discussed guidelines for improving the audit process. These issues were also discussed at several $Q$ meetings. The following guidelines were established:

- When appropriate, audit individuals and work not previously audited. Avoid auditing the same individual each time.

- Use QALs and YMP technicians as technical auditors.

- Check for consistency between the organization chart and position descriptions, and ensure that all people working on the YMP are in the organization chart.

- Ensure that personnel have had supervisor orientation and have taken the Orientation class, if required.

- Routinely check notebooks, TIPs, software, data submissions, and M\&TE.

- Before issuing audit plan, meet with investigators or QALs and determine what they have done the last year.

- Forward audit plan to QAPL two weeks before audit starts.

- Do not write a DR for deficient in-process records unless the deficiency has the potential to affect the quality of the work.

- If a DR is initiated, pencil in the name of the individual responsible for correcting the deficiency on the deficiency report form (or notify the Deficiency Report Coordinator).

- Assist the individual responsible for correcting the deficiency in formulating a corrective action.

- Identify repeat offenders.

\subsubsection{Goals for 1993.}

- Produce audit plans and reports in a timely manner.

- Close the two open stop work orders.

- QALs to participate as auditors on one audit, if possible.

- Use technical personnel as auditors.

As appropriate, utilize a performance-based approach.

The audit plans and reports, in general, were completed in a timely manner. One SWO was closed and the other will be closed when the new procedures are released in January 1994. Not all QALs were able to provide time as auditors. This didn't affect the verification staff since there were plenty of auditors. However, next year the QALs will be queried before the audit schedule is 
determined to see if this is a reasonable request. We were not successful in recruiting technical personnel as auditors. A performance-based approach was used as much as practical, although the YMP is primarily a compliance driven program currently. Over $50 \%$ of the goals were realized.

\subsubsection{Goals for 1994.}

- Have QALs visit subcontractors periodically.

- Keep the number of open deficiencies under ten.

- Conduct surveys to ensure compliance to new QPs.

- Encourage technical personnel to participate as auditors.

- Determine if QALs need to participate as auditors in one audit.

2.10 Deficiency Reporting System Mike Clevenger was selected as Deficiency Report Coordinator in April. The Q team had determined to decrease the number of open DRs in 1993 to less than twenty. This was realized in November.

In 1993, seventeen deficiencies were written, (eight deficiencies are not included, but rather tabulated with 1992 totals because they were issued in 1993 for problems recognized in December 1992 audits). Approximately 75\% of Los Alamos DRs were written as the result of the audit process; $25 \%$ were written by YMP personnel not part of the audit teams. These tabulations are shown in Table XIV. The decrease in DRs issued for 1992 is dramatic. It was estimated that each $\mathrm{DR}$ takes at least two man weeks to resolve, thus this results in significant manpower savings.

\subsubsection{Issues.}

The number of conflicts for writing acceptable deficiency descriptions continues to decrease. This is primarily the result of the Verification Coordinator and Deficiency Report Coordinator working with those involved to resolve problems.

The deficiency report procedure, QP-16.3, was revised. The process essentially remained the same, although the term deficiency report (DR) was replaced by corrective action report (CAR). The term $\mathrm{DR}$ has a negative connotation, whereas the term CAR is more in line with the DOE's procedure. The new procedure will become effective in 1994. Procedure QP-15.3 (Deficiency Reports) had remained open so that existing DRs would not have to be transferred to QP-16.3. This QP will be deleted, and any outstanding deficiencies under this QP will be transferred to the new system.

\subsubsection{Goals for 1993.}

- Reduce the number of outstanding deficiencies to less than twenty.

- Hold a root cause class for QALs and auditors.

All goals were realized.

\subsubsection{Goals for 1994 .}

- Reduce the number of outstanding deficiencies to less than fifteen.

- Revise the database for tracking deficiency reports. 
Table XII. Internal Audit Schedule.

\begin{tabular}{|c|c|c|c|c|c|c|c|c|c|c|c|c|}
\hline \multirow{2}{*}{ Date } & \multirow{2}{*}{$\begin{array}{l}\text { Los Alamos } \\
\text { Audit Number } \\
\text { \& Group }\end{array}$} & \multicolumn{11}{|c|}{ Criteria to be Audited } \\
\hline & & 1 & 2 & 3 & 4 & $\mathbf{5}$ & 6 & 7 & 8 & 12 & 13 & 17 \\
\hline $3 / 9-12$ & $\begin{array}{l}\text { AR-93-01 } \\
\text { EES-13/LV, } \\
\text { TCO }\end{array}$ & & * & * & & * & * & & * & & & * \\
\hline $4 / 19-22$ & $\begin{array}{l}\text { AR-93-02 } \\
\text { EES-1 }\end{array}$ & & * & * & * & * & * & * & * & * & & * \\
\hline $5 / 4-7$ & $\begin{array}{l}\text { AR-93-03 } \\
\text { EES-5 }\end{array}$ & & * & * & * & * & * & * & * & * & * & * \\
\hline $6 / 3-7 / 2$ & $\begin{array}{l}\text { AR-93-04 } \\
\text { EES-13/LV, } \\
\text { Volcanism } \\
\text { (EES-5, INC-6) }\end{array}$ & & * & * & * & * & * & * & * & * & * & * \\
\hline $\begin{array}{l}6 / 23- \\
7 / 2\end{array}$ & $\begin{array}{l}\text { AR-93-05 } \\
\text { Volcanism } \\
\text { (UNM) }\end{array}$ & & * & * & * & * & * & * & * & * & * & * \\
\hline $\begin{array}{l}6 / 10 \\
7 / 2\end{array}$ & $\begin{array}{l}\text { AR.93-06 } \\
\text { Volcanism } \\
\text { (Ohio St. Univ.) }\end{array}$ & & * & * & * & * & * & * & * & * & * & * \\
\hline $\begin{array}{l}6 / 28 \\
7 / 2\end{array}$ & $\begin{array}{l}\text { AR-93-04 } \\
\text { Volcanism } \\
\text { (EES-13/LV, } \\
\text { UC-Riverside) }\end{array}$ & * & * & * & * & * & * & * & * & * & & * \\
\hline $7 / 19-23$ & $\begin{array}{l}\text { AR-93-07 } \\
\text { EES-13 }\end{array}$ & & * & * & * & * & * & * & * & * & * & * \\
\hline $8 / 33-27$ & $\begin{array}{l}\text { AR-93-08 } \\
\text { EES-4, EES-15 }\end{array}$ & & * & * & * & * & * & * & * & * & * & * \\
\hline $9 / 13-14$ & $\begin{array}{l}\text { AR-93-09 } \\
\text { INC } \\
\text { (Stanford Univ.) }\end{array}$ & & * & * & * & * & * & * & * & * & * & * \\
\hline $9 / 15-17$ & $\begin{array}{l}\text { AR-93-10 } \\
\text { INC } \\
\text { (L. Berk. Lab) }\end{array}$ & & * & * & * & * & * & * & * & * & * & * \\
\hline $12 / 1-3$ & $\begin{array}{l}\text { AR-93-11 } \\
\text { INC } \\
\text { (H.GeoChem) }\end{array}$ & & * & * & * & * & * & * & * & * & * & * \\
\hline $11 / 16-19$ & $\begin{array}{l}\text { AR-93-12 } \\
\text { INC }\end{array}$ & & * & * & * & * & * & * & * & * & * & * \\
\hline
\end{tabular}


Table XIII. Internal Survey Schedule.

\begin{tabular}{||l|l|l|l|l||}
\hline $\begin{array}{l}\text { Survey Number \& } \\
\text { Organization } \\
\text { Surveyed }\end{array}$ & $\begin{array}{l}\text { Location of } \\
\text { Survey }\end{array}$ & \multicolumn{1}{|c|}{$\begin{array}{l}\text { Date of } \\
\text { Survey }\end{array}$} & \multicolumn{1}{|c|}{$\begin{array}{c}\text { Reason for } \\
\text { Survey }\end{array}$} & $\begin{array}{l}\text { Def } \\
\text { Reports } \\
\text { Issued }\end{array}$ \\
\hline \hline $\begin{array}{l}\text { SR-93-01 } \\
\text { (SIMCO) }\end{array}$ & $\begin{array}{l}\text { Los Alamos, } \\
\text { NM }\end{array}$ & $01 / 28 / 93$ & $\begin{array}{l}\text { Supplier, annual } \\
\text { evaluation }\end{array}$ & None \\
\hline $\begin{array}{l}\text { SR-93-02 } \\
\text { (EES-13) }\end{array}$ & $\begin{array}{l}\text { Los Alamos, } \\
\text { NM }\end{array}$ & $08 / 4-20 / 93$ & Interface Control & None \\
\hline $\begin{array}{l}\text { SR-93-03 } \\
\text { (Mettler } \\
\text { Instrument Corp.) }\end{array}$ & $\begin{array}{l}\text { Los Alamos, } \\
\text { NM }\end{array}$ & $04 / 18 / 93$ & $\begin{array}{l}\text { Supplier, annual } \\
\text { evaluation }\end{array}$ & None \\
\hline $\begin{array}{l}\text { SR-93-04 } \\
\text { EES-13/LV, } \\
\text { Volcanism) }\end{array}$ & $\begin{array}{l}\text { Las Vegas, } \\
\text { NV }\end{array}$ & $10 / 22-25 / 93$ & $\begin{array}{l}\text { Verify notebook } \\
\text { deficiencies fixed }\end{array}$ & None \\
\hline $\begin{array}{l}\text { SR-93-05 } \\
\text { Rainin Inst. Co.) }\end{array}$ & $\begin{array}{l}\text { Los Alamos, } \\
\text { NM }\end{array}$ & $10 / 26 / 93$ & $\begin{array}{l}\text { Supplier, annual } \\
\text { evaluation }\end{array}$ & None \\
\hline $\begin{array}{l}\text { SR-93-06 } \\
\text { (EES-13) }\end{array}$ & $\begin{array}{l}\text { Los Alamos, } \\
\text { NM }\end{array}$ & $12 / 9 / 93-01 / 14 / 94$ & RTN verification & None \\
\hline
\end{tabular}

Table XIV. Deficiencies Issued Annually.

\begin{tabular}{|c|c|}
\hline Year & Deficiency \\
\hline 1990 & 128 \\
\hline 1991 & 65 \\
\hline 1992 & 22 \\
\hline 1993 & 17 \\
\hline
\end{tabular}


2.11 Efforts to Increase Awareness of the Quality Program Four major activities were used to foster recognition of the quality program. The first was an annual YMP meeting in February to address YMP issues. Over sixty YMP personnel attended. Presentations included topics on quality assurance, regulatory issues, and the TCO (Table XV). Other activities included a State of the Project meeting, also held in February, at which C. Gertz provided a presentation on the "State of the YMP". Two quality program information brochures were issued in January and September. Lastly, on November 11, Los Alamos personnel attended the FY94 Kickoff meeting where major DOE organizational changes, new EES-13 staff, and a budget update were presented.

A Quality Forum was held in August. Frank Hawkins (DOE) and Mark Bodnarczuk (Fermi Lab) were guest speakers. In October there was an NRC/DOE Interaction Site Visit at the Laboratory. B. Romero was selected as the new Quality Concerns Coordinator. Quality concerns information brochures have been posted at various locations in the Laboratory and Las Vegas offices.

\subsubsection{Issues.}

The Los Alamos YMP information brochure (The Quality Connection) was only published twice due to funding constraints and other commitments. The brochure provided information on new regulations, current YMP events, and discussions on quality issues. This brochure has been a successful method of informing Los Alamos YMP personnel of quality issues, but has not been published regularly. This probably dilutes its message. It remains difficult for the QAPL to find time to allocate for providing this publication.

\subsubsection{Goals for 1993 .}

- Hold one annual all hands meeting.

- Publish the Quality Connection quarterly.

Two all hands meetings were held; however only two Quality Connection brochures were published. About $75 \%$ of the goals were realized.

\subsubsection{Goals for 1994 .}

- Hold one annual all hands meeting.

- Publish the Quality Connection at least twice.

Table XV. Program Agenda for the Annual YMP Meeting

\begin{tabular}{||l|l||}
\hline Subject & Speaker \\
\hline YMP QA- Heads and Tails & Stephen L. Bolivar, QAPL \\
\hline The PI and Closure & Chuck Harrington, EES-I \\
\hline Laboratory QA- How does it help the scientist? & John T. Whetten, ADQPP \\
\hline The TCO; Who are these guys? & Ned Z. Elkins, Deputy TPO \\
\hline We really do have a budget. & Julie A. Canepa, TPO \\
\hline
\end{tabular}




\subsection{TREND ANALYSIS}

3.1 Introduction. The purpose of this section is to summarize the four trend reports issued in 1993. DOE and internal audit and surveillance reports, stop work orders, and other quality assurance documents, such as the corrective action report log, are examined periodically to determine if any adverse trends exist and to give the status of any previously recognized adverse trends.

An adverse trend is defined as a repetitive or frequent occurrence of a condition adverse to quality, or occurrence of similar conditions adverse to quality that suggest a systematic weakness in the quality program. Adverse trends in this status report can be compared with past and future reports to evaluate the quality program.

The number of deficiencies issued during a calendar year can provide a first approximation of the status of a quality assurance program. In calendar year 1991, 65 internal deficiencies were issued. In 1992, 22 were issued. In 1993, the total was 17, still showing a decrease.

However, a quality assurance program consists of many parts in which problems may occur (e.g. program development, verification activities, training, etc). This section examines not only the frequency of deficiencies but also includes comparisons of both Los Alamos groups and other Participants.

3.2 Methodology. The Los Alamos deficiency report (DR) log was examined to determine the status of deficiencies. Individual DRs were then examined and categorized. First, in accordance with previous progress reports, DRs were grouped according to the quality administrative procedure the deficiency occurred in. The procedure's revision number and section in which the violation occurs are recorded, if known (Appendix E). This allows identification of procedures that are habitually violated. Deficiencies are then categorized according to the Los Alamos group that the deficiency was assigned to. This category can be examined to identify groups that are assigned large numbers of deficiencies.

The probable causes of deficiencies, when available, are examined and categorized into a) not trained to procedure, b) failure to follow procedural guidance, c) conflicting procedural guidance, and d) oversight. There also is a category for deficiencies written against measuring and test equipment (M\&TE) out of calibration. It is possible for a single deficiency to occur in more than one category.

A similar categorization is done for corrective action reports (CARs) received from DOE audits and surveys. However, a group category is not identified because the deficiency usually is a Laboratorywide occurrence.

Lastly, DOE and Los Alamos audit and survey reports, and Los Alamos conflict resolution and stop work order logs are examined. Most deficiencies are captured in the Los Alamos DR log, therefore these reports are used predominantly to identify deficiencies that have been fixed during audits and surveys. Conflict resolution and stop work order logs are examined on a case by case basis because occurrences in these logs are not always associated with a deficiency.

3.3 Internal Audits and Surveys. During 1993 twelve audits were conducted. All audit reports were issued within two to three weeks after the audit was completed. Table XVI lists the findings. 
Table XVI. Summary of Internal Audit Findings .

\begin{tabular}{|c|c|c|c|c|}
\hline Audit Number & Group & $\begin{array}{l}\text { Number of } \\
\text { Deficiencies } \\
\text { Identified }\end{array}$ & $\begin{array}{l}\text { Deficiency } \\
\text { Reports } \\
\text { Issued } \\
\end{array}$ & $\begin{array}{l}\text { Implementation } \\
\text { Acceptable }\end{array}$ \\
\hline LANNL-AR-93-01 & TCO & Eight & DR 217 & Yes \\
\hline LANL-AR-93-02 & EES-1 & Six & $\begin{array}{l}\text { DR } 219 \\
\text { DR } 220 \\
\text { DR } 221 \\
\text { (issued to } \\
\text { records) }\end{array}$ & $\begin{array}{l}\text { Criterion } 2 \text { needs } \\
\text { attention }\end{array}$ \\
\hline LANL-AR-93-03 & EES-5 & None & None & Yes \\
\hline LANL-AR-93-04 & $\begin{array}{l}\text { EES-13 } \\
\text { Volcanism } \\
\text { (EES-5, INC-6, } \\
\text { UC Riverside) }\end{array}$ & Eighteen & None & $\begin{array}{l}\text { Criteria } 3,8,12 \\
\text { need attention }\end{array}$ \\
\hline LANL-AR-93-05 & $\begin{array}{l}\text { EES-13 } \\
\text { Volcanism } \\
\text { (UNM) }\end{array}$ & One & None & Yes \\
\hline LANL-AR-93-06 & $\begin{array}{l}\text { EES-13 } \\
\text { Volcanism } \\
\text { (OSU) }\end{array}$ & Two & None & Yes \\
\hline LANL-AR-93-07 & EES-13 & Nine & $\begin{array}{l}\text { DR } 225 \\
\text { DR } 226 \\
\text { DR } 227\end{array}$ & $\begin{array}{l}\text { Criteria } 2,5,8 \text { need } \\
\text { attention }\end{array}$ \\
\hline LANL-AR-93-08 & EES-4 \& EES-15 & None & & Yes \\
\hline LANL-AR-93-09 & INC (SU) & Thirteen & DR 229 & $\begin{array}{l}\text { Criteria } \\
2,4,6,7,12,17 \text { need } \\
\text { attention }\end{array}$ \\
\hline LANL-AR-93-10 & INC (LBL) & Eighteen & DR 230 & $\begin{array}{l}\text { Criteria } 2,4 \text { need } \\
\text { attention }\end{array}$ \\
\hline LANL-AR-93-11 & $\begin{array}{l}\text { INC } \\
\text { (HydroGeoChem) }\end{array}$ & None & None & Yes \\
\hline LANL-AR-93-12 & INC & Seventeen & $\begin{array}{l}\text { DR } 231 \\
\text { DR } 232\end{array}$ & $\begin{array}{l}\text { Criteria } 2,3,4,6,17 \\
\text { need attention }\end{array}$ \\
\hline
\end{tabular}


One situation deserves comment. The number of deficiencies for some groups is higher than might be expected. Most of the recognized problems are minor and have to do with lack of attention to detail. More importantly', in general, the number of formal deficiency reports (DRs) has decreased. To see if a problem truly exists, specific deficiencies have to be examined. However, because all QPs are scheduled to be revised in 1994, it may be several months before any adverse trends become apparent. To ensure that potential problems can be addressed, more QAL assistance has been allocated for group EES-1 and for some of the contractors. The pervasive lack of attention to detail is a Laboratory-wide issue, and it will cease only when quality assurance is an everyday part of an investigator's normal routine. Lastly, the increase in deficiencies is partly attributable to a new way of accounting, i.e. each deficiency is listed separately. Since deficiencies corrected during audits are not a serious problem to begin with, the relative seriousness of these minor problems must be kept in perspective. These deficiencies do not appear to be indicative of major problems.

3.4 Internal Deficiencies. From January through December, 1993, twenty-five deficiency reports were issued. However, several 1992 audit reports were not completed until January 1993, whereby eight DRs were issued. Since these were issued for problems recognized in December 1992 audits, the eight DRs are included with 1992 averages. Thus only seventeen DRs are attributed to 1993 activities; this compares to twenty two DRs issued in 1992. The total DRs issued since 1990 shows an annual decrease. The actual DRs are listed in Table XVII.

3.5 Stop Work Orders and Conflict Resolutions. Stop work orders (SWOs) are not to be used as a punitive measure, but rather to selectively stop activities. Stop work order SWO-LA-08 was issued against the computational data section of the software procedures. This was based on a management decision that control will be through the notebook procedure rather than through the configuration management process. SWO-LA-08 will be closed after the software procedures are revised (Table XVIII). Stop work order (SWO-LA-03) was closed when the appropriate record package had been fixed. No new conflict resolutions occurred.

3.6 DOE Audits, Surveillances, and Issued Deficiencies. The DOE conducted two surveillances and one audit in 1993 (Table XIX). Although three deficiencies were fixed during the audit and three corrective action reports (CARs) were written, Los Alamos performed satisfactorily in the audited criteria. The surveillances were conducted to check on sampling issues (YMP-SR-93-046) and to verify implementation of a job package (YMP-SR-94-014). There were no findings. The Los Alamos YMP ended 1993 with no open CARs. This is the first time since the deficiency program began in 1989 that there were no open CARs. The 1993 CAR status activity is shown in Table XX. Adverse trends are described in Section 3.7.

3.7 Status of Adverse Trends and Significant Conditions Adverse to Quality. There were no significant conditions adverse to quality (SCAQ) issued in the last twelve months. In our program, only one SCAQ has been issued (for lack of a software program), and it was closed in 1990.

A list of adverse trends is shown in Table XXI. In 1993, trend AT-91-01 was closed. Adverse trend 
Table XVII. Internal Deficiency Reports Issued in 1993.

\begin{tabular}{|l|l|l||}
\hline $\begin{array}{c}\text { Deficiency } \\
\text { Report }\end{array}$ & \multicolumn{1}{|c|}{ Group } & \multicolumn{1}{|c|}{ Description } \\
\hline DR 216 & EES-13, M\&TE & $\begin{array}{l}\text { Not trained to latest M\&TE procedure (training was done } \\
\text { but not documented) }\end{array}$ \\
\hline DR 217 & EES-13, TCO & QP draft missing header pages \\
\hline DR 218 & LATA, Records & Inventory list missing (self imposed excessive requirement) \\
\hline DR 219 & EES-1 & Not trained to DP \\
\hline DR 220 & EES-1, M\&TE & Notebook entry not ID M\&TE uniquely \\
\hline DR 221 & EES-13, Records & Records Coordinator not trained to QP-06.3 \\
\hline DR 222 & EES-13, Software & Life cycle software procedures not followed \\
\hline DR 223 & LATA & Unauthorized signature and wrong TWS\# assigned \\
\hline DR 224 & EES-4 & No QAL review on purchase request \\
\hline DR 225 & EES-13, Data & Data Coordinator did not follow procedure \\
\hline DR 226 & EES-13, QA & QP Action Request not signed \\
\hline DR 227 & EES-13 & WBS number not on PD \\
\hline DR 228 & EES-1, M\&TE & Balance out of calibration \\
\hline DR 229 & SU & PQEF form not verified \\
\hline DR 230 & LBL & Proficiency evaluation not done \\
\hline DR 231 & INC & PQEF form not verified \\
\hline DR 232 & INC & Incorrect reference to DP \\
\hline \hline
\end{tabular}

AT-93-01 will remain open until our procedures are revised to meet the new QARD requirements.

Internal DRs and DOE deficiencies issued in the last twelve months were examined (Tables XVII and $\mathrm{XX}$ ). The majority of deficiencies represent isolated instances of nonconformance. However, one situation may be developing that will require further surveillance. This is discussed in the following paragraphs.

Deficiency reports DR 216, 219, 221 and CAR YM-93-051 involve training. Deficiency DR 216 was a minor infraction where the training was done but the documentation was not correctly dual stored. The DR 221 revealed the Records Coordinator had to unnecessarily train to a procedure. The CAR had to do with poor verbiage in a procedure that required all limited function employees to train to orientation. This was not the intent. These procedures have since been fixed. Only DR 219 involved someone actually not trained. 
DRs 222 and CARs 93-018 and 019 have to do with software. Since the software procedures will be revised in 1994, and all three deficiencies are minor in nature, no further action is planned. Two DRs, 220 and 228, and CAR YM-93-051 involve M\&TE; however, one deficiency had to do with an improper notebook entry, one had to do with a traceability issue within a record package, and the third had to do with an instrument out of calibration. No adverse trends are recognized.

Table XVIII. Status of Los Alamos Stop Work Orders (SWO) and Conflict Resolutions (CR)

\begin{tabular}{||l|l|l||}
\hline SWO or CR & \multicolumn{1}{|c|}{ Description } & Status \\
\hline \hline SWO-LA-01 & Software Stop Work & Closed 1-28-91 \\
\hline SWO-LA-02 & SEA failed to follow QPs in criterion two & Closed 3-4-92 \\
\hline SWO-LA-03 & Volcanism/USGS failed to follow QPs & Closed 11-3-93 \\
\hline SWO-LA-04 & HydroGeoChem had inadequate QA program & Closed 11-4-90 \\
\hline SWO-LA-05 & Bid evaluation section missing in QP-04.5 & Closed 12-15-92 \\
\hline SWO-LA-06 & QP-03.5 and QP-03.17 are in conflict & Closed 12-15-92 \\
\hline SWO-LA-07 & Prevent sending records to YMP until QP-17.3 revised & Closed 3-4-92 \\
\hline SWO-LA-08 & Against SQAP, Fig. 1 \& Computational Data QP & Open \\
\hline LA-CR-001 & Purchase request protocol & Resolved \\
\hline
\end{tabular}

Table XIX. 1993 DOE Audits and Surveys of the Los Alamos YMP.

\begin{tabular}{||l|l|l||}
\hline \multicolumn{1}{|c|}{ Activity } & \multicolumn{1}{|c|}{ Date } & \multicolumn{1}{c|}{ Result } \\
\hline \hline Audit YMP-93-011 & May 24-28 & $\begin{array}{l}\text { Three deficiencies fixed during audit, } \\
\text { CARs 93-049, -050, -051 issued. }\end{array}$ \\
\hline Survey YMP-SR-93-046 & Sept 30-Oct 26 & No deficiencies. \\
\hline Survey YMP-SR-94-014 & Dec 6 & No deficiencies. \\
\hline
\end{tabular}


Table XX. Status of Los Alamos Corrective Action Reports.

\begin{tabular}{||l|l|l||}
\hline \multicolumn{1}{|c|}{ Deficiency } & \multicolumn{1}{|c|}{ Result } & \multicolumn{1}{|c|}{ Status } \\
\hline \hline $\begin{array}{l}\text { CAR YM-91-041 } \\
\text { (QAPP and procedures are not } \\
\text { consistent) }\end{array}$ & $\begin{array}{l}\text { Audit } \\
\text { YMP 91-03 }\end{array}$ & Closed 12/7/93 \\
\hline $\begin{array}{l}\text { CAR YM-92-058 } \\
\text { (Notebook review not done) }\end{array}$ & Surveillance YMP-SR-92-006 & Closed 1/29/93 \\
\hline $\begin{array}{l}\text { CAR YM-93-018 } \\
\text { (Software- minor procedural violation) }\end{array}$ & Audit YMP-93-02 & Closed 2/25/93 \\
\hline $\begin{array}{l}\text { CAR YM-93-019 } \\
\text { (Software- minor procedural violation) }\end{array}$ & Audit YMP-93-02 & Closed 1/15/93 \\
\hline $\begin{array}{l}\text { CAR YM-93-049 } \\
\text { (Interface procedure not followed) }\end{array}$ & Audit YMP-93-11 & Closed 11/17/93 \\
\hline $\begin{array}{l}\text { CAR YM-93-050 } \\
\text { (record package pages not numbered) }\end{array}$ & Audit YMP-93-11 & Closed 8/12/93 \\
\hline $\begin{array}{l}\text { CAR YM-93-051 } \\
\text { (Training requirements in question- } \\
\text { minor procedural violation) }\end{array}$ & Audit YMP-93-11 & Closed 11/2/93 \\
\hline
\end{tabular}

3.8 Participant Comparisons. Many factors, such as the scope and complexity of work, contribute to the effectiveness of a Participant's quality program. However, if one compares the total number of deficiencies issued (and fixed) during YMP audits and surveillances, a relative measure of compliance to regulations can be inferred. For calendar year 1992 the Los Alamos quality program favorably compares to other Participant's programs. Discussion of this comparison follows.

To determine the status of the Los Alamos quality program with respect to other Project Participants' programs, the number of deficiencies identified during 1993 YMP audits and surveillances were plotted for each Participant. Figure 2 shows data for deficiencies issued during annual audits. These data include deficiencies fixed during audits. The deficiencies are scaled, i.e. those fixed during audits are assigned one point, and those issued are assigned two points.

Unfortunately, Fig. 2 gives a somewhat biased view of a Participant's program. Figure 2 does not include CARS issued as the result of surveillances or other assessment activities. The US Department of Energy Office of Civilian Radioactive Waste Management (1993) issued a report that tabulates all CARS issued to Participants (Fig 3). This is probably a better representation of a Participant's overall program.

Deficiencies issued to Los Alamos for the period 1987 to 1993 are displayed in Fig. 4. The number of formal deficiencies issued, as well as the number of deficiencies fixed during audits (fixes), generally decreases from 1987 to 1992 . This indicates a trend of annual improvement. There also is a noticeable decrease in the number of deficiencies issued post 1991 compared to previous years. Los Alamos personnel have made significant improvements in their quality efforts post 1991. 
Table XXI. Adverse Trends.

\begin{tabular}{|c|c|c|}
\hline Trend & Trend Description & Status \\
\hline AT-91-01 & $\begin{array}{l}\text { Excessive number of DRs issued against QAPP } \\
\text { (QAPP and QPs not consistent). }\end{array}$ & $\begin{array}{l}\text { Closed } \\
\text { (CAR-90-041 closed on } \\
\text { 12-7-93) }\end{array}$ \\
\hline AT-91-02 & $\begin{array}{l}\text { Excessive number of DRs issued against QP-02.5. } \\
\text { QP-02.5 needs to be revised. }\end{array}$ & $\begin{array}{l}\text { Closed } \\
\text { (QP-02.5 issued on } \\
9-30-91)\end{array}$ \\
\hline AT-91-03 & $\begin{array}{l}\text { Excessive number of DRs issued against QPs-03.3 } \\
\text { and -03.2. Procedures hard to follow and Project } \\
\text { guidance for QP-03.3 has changed. Procedure } \\
\text { needs to be revised. }\end{array}$ & $\begin{array}{l}\text { Closed } \\
\text { (QP-03.23 issued on } \\
\text { 3-16-92; QPs-03.2 \& }-03.3 \\
\text { superseded) }\end{array}$ \\
\hline AT-91-04 & $\begin{array}{l}\text { Excessive number of DRs issued against QP-03.5. } \\
\text { Conflicting guidance for notebook corrections with } \\
\text { QP-17.3. Need to revise QP-03.5. }\end{array}$ & $\begin{array}{l}\text { Closed } \\
(\mathrm{QP}-03.5 \text { issued } 12-7-92)\end{array}$ \\
\hline AT-91-05 & $\begin{array}{l}\text { Excessive number of DRs issued against QP-04.1 in } \\
\text { 1990. Requirements are confusing and overly } \\
\text { restrictive. Need to revise QP-04.1. }\end{array}$ & $\begin{array}{l}\text { Closed } \\
\text { (QP-04.1 superseded by } \\
\text { QP-04.4 on } 11-15-91 \& \\
\text { QP-04.5 on } 12-23-91 \text { ) } \\
\end{array}$ \\
\hline AT-91-06 & $\begin{array}{l}\text { Excessive number of } \mathrm{DRs} \text { issued against QP-12.1. } \\
\text { Procedure is difficult to follow. Need to revise QP- } \\
\text { 12.1. }\end{array}$ & $\begin{array}{l}\text { Closed } \\
\text { (QP-12.1 issued on } \\
5-8-92)\end{array}$ \\
\hline AT-91-07 & $\begin{array}{l}\text { Excessive number of DRs issued against QP } 17.3 . \\
\text { Procedure needs to be simplified and new Project } \\
\text { requirements incorporated. }\end{array}$ & $\begin{array}{l}\text { Closed } \\
\text { (QPs-17.4 \& -17.5 issued } \\
\text { on 2-28-92; SWO-LA-07 } \\
\text { lifted 3-4-92) }\end{array}$ \\
\hline AT-93-01 & $\begin{array}{l}\text { Excessive number of DRs issued against software } \\
\text { program. Software procedures to be revised. }\end{array}$ & Open \\
\hline
\end{tabular}

3.9 Group Trends. During the calendar year the Los Alamos Verification Coordinator conducted several internal audits of various groups, including subcontractors, working on Los Alamos YMP activities. The number of internal deficiencies issued against these groups for the last three years is shown in Table XXII.

The number of deficiencies a particular group receives reflects several factors. For example, management groups might have more deficiencies simply because all activities are coordinated through these offices. Certain groups might have several deficiencies simply because of the volume of activity associated with their activity. In other words, the number of deficiencies issued against a group must be placed in overall context before it can be considered significant.

The number of formal deficiency reports issued to any respective group in 1993 is about the same as the level for the last two years. However, the number of deficiencies fixed during audits is 
significantly increased for several groups. The majority of these problems have to do with lack of attention to detail, mostly with record packages for notebooks. A record management class will be developed in 1994 to stress the importance of attention to detail.

Table XXII. Los Alamos Deficiencies by Group.

\begin{tabular}{||l|l|l|l||}
\hline \multicolumn{1}{|c|}{ Group } & \multicolumn{1}{c|}{1991} & \multicolumn{1}{c|}{1992} & \multicolumn{1}{c||}{1993} \\
\hline \hline EES-1 & 5 (5 fixes) & 2 (3 fixes) & 3 (6 fixes) \\
\hline EES-4 & 2 (1 fix) & 0 (1 fix) & 1 \\
\hline EES-5 & 7 & 0 (4 fixes) & 0 \\
\hline $\begin{array}{l}\text { EES-13 } \\
\text { Management }\end{array}$ & 10 & 0 (1 fix) & 3 (9 fixes) \\
\hline EES-13 Software & N/A & 7 (1 fix); SWO-08 & 1 \\
\hline EES-13/LV TCO & 0 (4 fixes) & 0 & 1 (8 fixes) \\
\hline $\begin{array}{l}\text { EES-13/LV, } \\
\text { VOLC }\end{array}$ & 0 (3 fixes) & 2 (5 fixes) & 0 (18 fixes) \\
\hline EES-15 & 1 (1 fix) & 0 (1 fixes) & 0 \\
\hline INC & 10 (4 fixes) & 1 & 3 (17 fixes) \\
\hline UC-Riverside & 0 & 0 & 0 \\
\hline UNM & 3 (3 fixes) & 1 (3 fixes) & 0 (1 fix) \\
\hline LBL & 5 (8 fixes) & 1 (3 fixes) & 0 (18 fixes) \\
\hline SU & 3 (3 fixes) & N/A & 1 (13 fixes) \\
\hline HGC & 2 (2 fixes) & 1 & 0 \\
\hline OSU/CS & 1 (2 fixes) & 0 (3 fixes) & 0 (2 fixes) \\
\hline M\&TE & 1 & 0 & 1 \\
\hline Records & $1 ;$ SWO-07 & 1 & 2 \\
\hline Controlled Docs & 0 & 0 & 0 \\
\hline Training & 1 & 0 & 0 \\
\hline Audits & 3 & 1 & 0 \\
\hline QA Organization & $7 ;$ SWO-05, 06 & 2 & 2 \\
\hline
\end{tabular}

Key: N/A=Not applicable; SWO=Stop Work Order; All INC groups combined under INC; Deficiencies fixed during audits are listed in parentheses. 


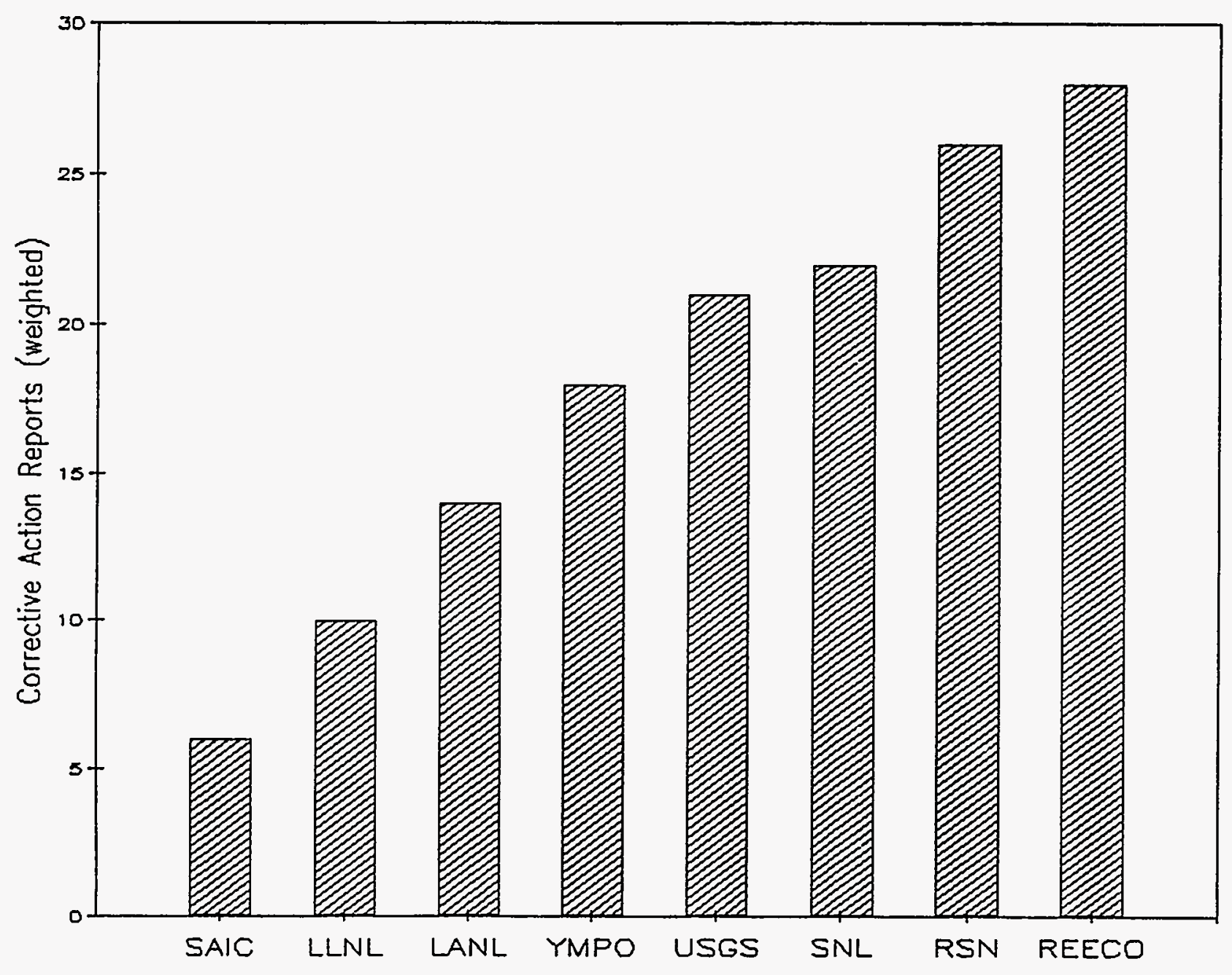

Fig. 2. Corrective Action Reports Resulting From DOE Audits. Corrective action reports are weighted; those formally issued are multiplied by two, whereas those fixed during audits are multiplied by one. (Key: SAIC $=$ Scientific Applications International Corporation; LLNL= Lawrence Livermore National Laboratory; LANL= Los Alamos National Laboratory; YMPO= Yucca Mountain Project Office; USGS= United States Geological Survey; SNL= Sandia National Laboratories; RSN= Rayethon Services Nevada; REECO= Reynolds Electric Company). 


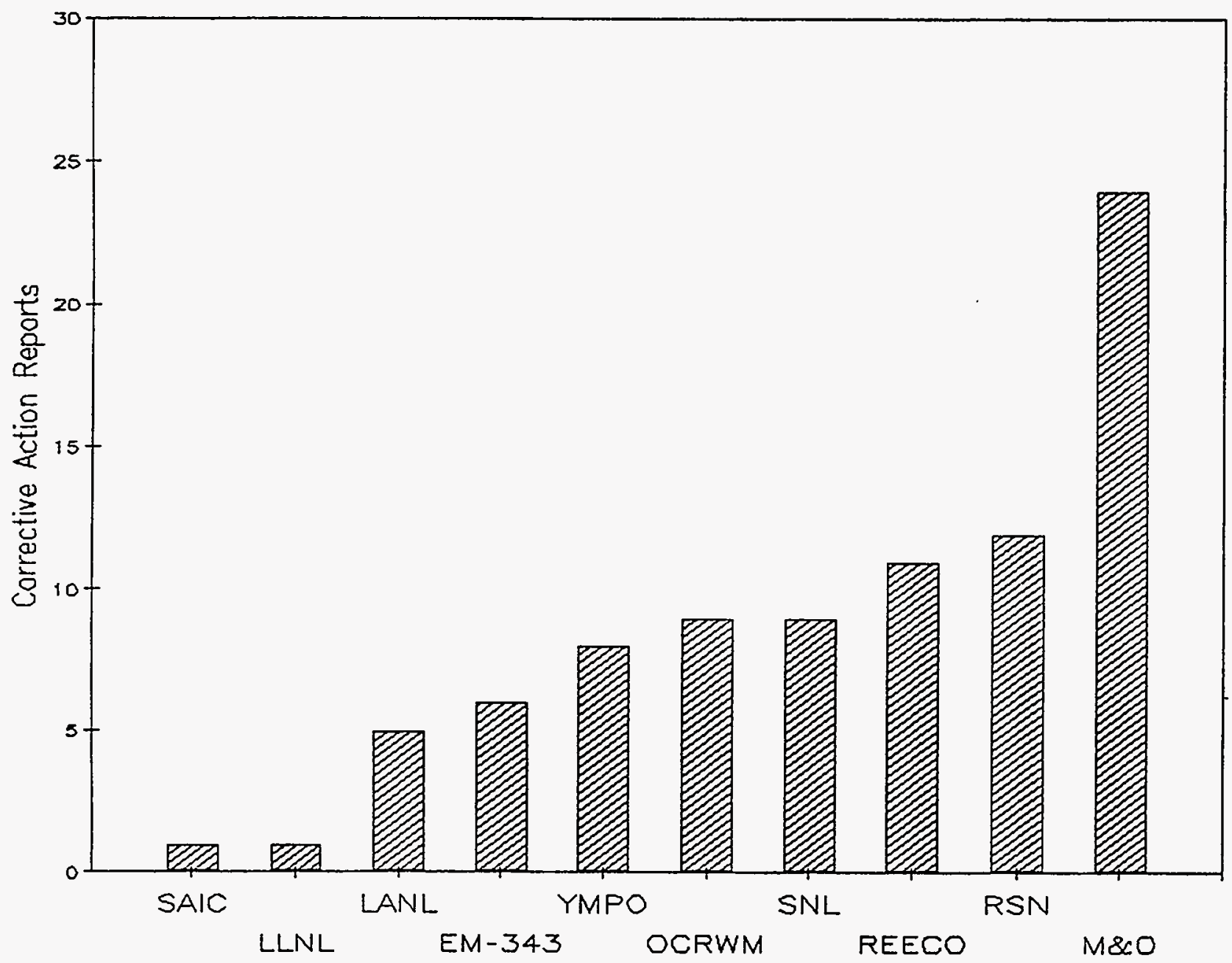

Fig. 3. Corrective Action Reports Resulting From All DOE Verification Activities. The corrective action reports are not weighted. (Key: SAIC= Scientific Applications International Corporation; LLNL= Lawrence Livermore National Laboratory; LANL= Los Alamos National Laboratory; EM343 is a Washington DC Department of Energy group working on YMP issues; YMPO= Yucca Mountain Project Office; OCRWM= Office of Civilian Radioactive Waste Management; SNL= Sandia National Laboratories; REECO= Reynolds Electric Company; RSN= Rayethon Services Nevada; $\mathrm{M} \& \mathrm{O}=$ Management and Operations Contractor). 


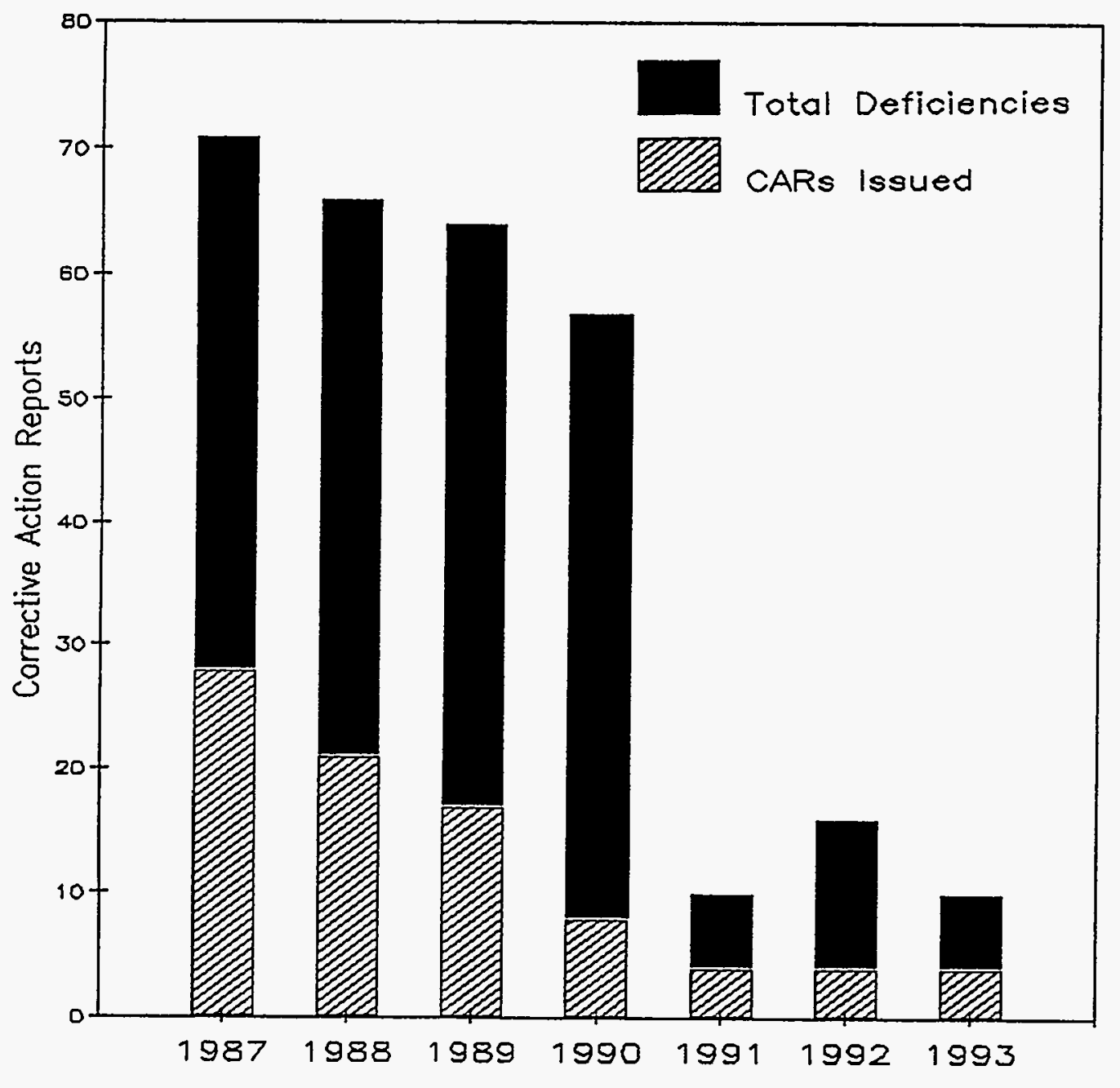

Fig. 4. Corrective Action Reports Assigned to Los Alamos by the DOE. Plot shows both total deficiencies identified (solid bars) and deficiencies issued as a corrective action report (stippled bars). Deficiencies are for audits and surveillances and are not weighted. 
3.10 Possible Adverse Trends Associated with Criteria or Procedures. The DR log was examined and deficiencies were categorized by assigning them to the respective QARD criterion they are associated with. A large number of DRs associated with a criterion does not necessarily signify an adverse trend, but does help identify areas of concern. Figure 5 shows this data grouped by criteria; obviously criteria two and three are possible areas of concern. However, to determine if an adverse trend exists, the data must be examined in greater detail.

Appendix E lists the number of deficiencies issued for respective QPs. Table XXIII shows those current procedures for which more than two deficiencies were issued in 1993. An adverse trend might be suspected if the number of deficiencies associated with any one $Q P$ is large; however, recognition of adverse trends by this method is very subjective. One must look at the reasons for each deficiency before a true adverse trend can be identified.

Table XXIII. Deficiencies issued correlated with Procedures (only those with more than 2 deficiencies are listed).

\begin{tabular}{|c|c|}
\hline Plan or Procedure & $\begin{array}{c}\text { Number of } \\
\text { Deficiencies }\end{array}$ \\
\hline QP-02.5 & 6 \\
\hline QP-02.7 & 6 \\
\hline QP-02.11 & 3 \\
\hline QP-03.5 & 4 \\
\hline QP-04.4 & 3 \\
\hline QP-06.1 & 3 \\
\hline QP-12.1 & 4 \\
\hline QP-17.4 & 6 \\
\hline
\end{tabular}

A possible adverse trend might be suggested by the magnitude of deficiencies associated with a specific procedure, e.g. there are numerous deficiencies associated with QPs-02.5, -02.7 and -17.4. However, the number of deficiencies is not considered excessive because of the volume of activity related to these procedures. The only common thread might be a lack of attention to detail. A record management class will be developed in 1994 to address this issue. However, the number of deficiencies found is not excessive for the amount of work done, and since all procedures will be revised in 1994 to conform to new QARD requirements, it is a moot point to further discuss potential adverse trends.

3.11 Trends Identified with Probable Cause Determination. After examining all Los Alamos internal DRs, it became evident that probable causes could be placed into a select number of 
categories. This assumes that the resolver of a DR did a correct probable cause determination, and this may not be valid for all DRs. However, this approach does reveal some interesting information.

The probable cause categories are a) not trained (Table XXIV), b) failure to follow procedural guidance (Table XXV), c) conflicting procedural guidance (Table XXVI), d) oversight (Table XXVII), and e) M\&TE (Table XXVIII). These data are shown in Fig. 6. Large numbers of associated deficiencies do not necessarily identify an adverse trend; as mentioned above, the data must be placed into context of the overall program.

Probable causes attributed to failure to follow procedural guidance category (Table XXV), oversight (Table XXVII)and M\&TE (Table XXVIII) are decreased or similar to 1991 and 1992 levels. These totals do not merit further discussion.

There is a noticeable increase in causes attributable to lack of training and conflicting procedural guidance (Tables XXIV and XXVI). The training issue was discussed in Section 3.7; there does not appear to be a significant trend associated with the training issue.

The problems with failure to follow procedural guidance are difficult to quantify because there are a large number of possible causes. A procedure may be to difficult to follow. Or possibly, deficiencies may have been issued to individuals with an attitude problem. After examining individual DRs, it appears that this category resulted from procedures providing poor or conflicting guidance. As the YMP matures and as individuals become more familiar with processes, the bugs get worked out. In both training and failure to follow procedural guidance, the majority of problems can be attributed to oversights or failure to pay attention to detail, and the problems are comparatively minor. No adverse trends are recognized.

Table XXIV. Deficiencies Attributed to Lack of Training (numbering scheme explained in Appendix E).

\begin{tabular}{|c|c|c|c|c|c|}
\hline & 1991 & & 1992 & \multicolumn{2}{|c|}{1993} \\
\hline \multicolumn{2}{|c|}{$\begin{array}{l}\text { Deficiency/ } \\
\text { Associated Procedure }\end{array}$} & \multicolumn{2}{|c|}{$\begin{array}{l}\text { Deficiency/ } \\
\text { Associated Procedure }\end{array}$} & \multicolumn{2}{|c|}{$\begin{array}{l}\text { Deficiency/ } \\
\text { Associated Procedure }\end{array}$} \\
\hline DR 133 & QP-17.3 & $92-13-001$ & QP-03.5 & DR 216 & QP-17.4 \\
\hline DR 145 & QP-03.3 & DR 213 & QP-06.2 & DR 216 & QP-12.1 \\
\hline DR 147 & QP-03.3 & DR 205 & QP-02.7 & DR 219 & DP-101 \\
\hline DR 150 & $\mathrm{QP}-04.1$ & DR 207 & LBL-DP-13 & DR 221 & QP-06.3 \\
\hline DR 156 & SQAP & DR 214 & QP-06.2 & CAR-93-051 & QP-17.4 \\
\hline DR 173 & QP-03.5 & DR 213 & QP-06.2 & $93-04-04$ & DP 606 \\
\hline DR 192 & DP 14 & & & $93-12-05$ & QP-06.1 \\
\hline \multirow[t]{6}{*}{ DR 187} & DP 35 & & & $93-09-04$ & QP-06.1 \\
\hline & & & & $93-05-01$ & QP-02.7 \\
\hline & & & & $93-10-03$ & QP-02.11 \\
\hline & & & & $93-12-03$ & DP 86 \\
\hline & & & & $93-09-03$ & QP-04.4 \\
\hline & & & & $93-10-02$ & QP-02.7 \\
\hline
\end{tabular}



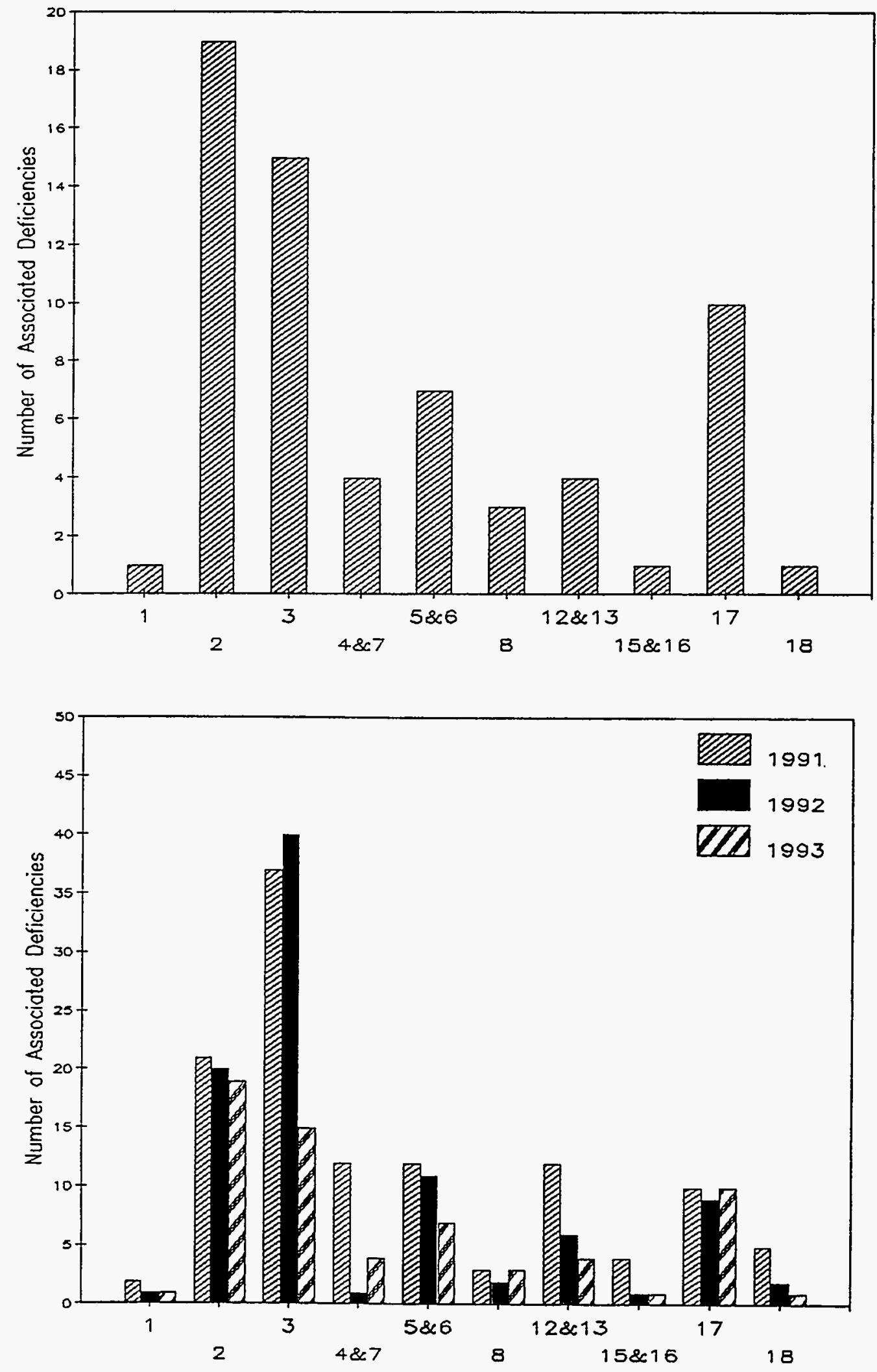

Fig. 5. Internal Deficiencies Correlated by Criteria. Top graph shows deficiencies associated with respective QARD criteria for 1993, whereas bottom graph shows the data for 1991-1993. Deficiencies include both those formally issued and those fixed during internal audits. 
Table XXV. Deficiencies Attributed to Failure to Follow Procedural Guidance (numbering scheme explained in Appendix E).

\begin{tabular}{|c|c|c|c|c|c|}
\hline \multicolumn{2}{|l|}{1991} & \multicolumn{2}{|l|}{1992} & \multicolumn{2}{|l|}{1993} \\
\hline Deficiency & $\begin{array}{l}\text { Deficiency } \\
\text { Fixed }\end{array}$ & Deficiency & $\begin{array}{l}\text { Deficiency } \\
\text { Fixed }\end{array}$ & Deficiency & $\begin{array}{l}\text { Deficiency } \\
\text { Fixed }\end{array}$ \\
\hline $\begin{array}{l}\text { DR } 132 \\
\text { DR } 133 \\
\text { DR } 135 \\
\text { DR } 138 \\
\text { DR } 139 \\
\text { DR } 140 \\
\text { DR } 141 \\
\text { DR } 142 \\
\text { DR } 144 \\
\text { DR } 147 \\
\text { DR } 148 \\
\text { DR } 149 \\
\text { DR } 151 \\
\text { DR } 152 \\
\text { DR } 154 \\
\text { DR } 158 \\
\text { DR } 159 \\
\text { DR } 160 \\
\text { DR } 161 \\
\text { DR } 162 \\
\text { DR } 163 \\
\text { DR } 164 \\
\text { DR } 165 \\
\text { DR } 166 \\
\text { DR } 167 \\
\text { DR } 168 \\
\text { CAR-91-041 } \\
\text { CAR-92-002 } \\
\text { CAR-92-001 } \\
\text { CAR-92-003 } \\
\text { DR } 170 \\
\text { DR } 173 \\
\text { DR } 174 \\
\text { DR } 178 \\
\text { DR } 179 \\
\text { DR } 180 \\
\text { DR } 184 \\
\text { DR } 185 \\
\text { DR } 186 \\
\text { DR } 189 \\
\text { DR } 188 \\
\text { DR } 187 \\
\text { DR } 191 \\
\text { DR } 192 \\
\text { DR } 193 \\
\end{array}$ & $\begin{array}{l}\text { YA-91-03-1 } \\
\text { YA-91-03-2 } \\
\text { YA-91-03-7 } \\
\text { YA-91-03-9 } \\
91-002-3 \\
91-003-1 \\
91-003-2 \\
91-003-4 \\
91-004-1 \\
91-004-3 \\
91-006-1 \\
91-008-1 \\
91-008-2 \\
91-008-3 \\
91-008-4 \\
91-013-2 \\
91-013-3 \\
91-003-5 \\
91-14-1 \\
91-14-2 \\
91-15-1 \\
91-10-1 \\
91-10-2 \\
91-11-1 \\
91-11-2 \\
91-11-3\end{array}$ & $\begin{array}{l}\text { DR } 194 \\
\text { DR } 196 \\
\text { DR } 197 \\
\text { DR } 198 \\
\text { DR } 200 \\
\text { DR 202 } \\
\text { CAR-92-058 } \\
\text { DR 206 } \\
\text { DR 209 } \\
\text { DR 211 } \\
\text { DR 214 } \\
\text { DR 215 } \\
\text { DR 208 } \\
\text { DR } 210\end{array}$ & $\begin{array}{l}92-001-2 \\
92-002-1 \\
92-002-2 \\
92-002-5 \\
92-003-3 \\
\text { YA-92-12-01 } \\
\text { YA-92-12-02 } \\
\text { YA-92-12-03 } \\
92-006-3 \\
92-10-002 \\
92-10-003 \\
92-13-002\end{array}$ & $\begin{array}{l}\text { DR } 217 \\
\text { DR } 225 \\
\text { DR } 227 \\
\text { DR } 222\end{array}$ & $\begin{array}{l}93-01-01 \\
93-07-01 \\
93-09-02 \\
93-10-03 \\
93-12-01 \\
93-12-04 \\
93-10-01 \\
93-10-04\end{array}$ \\
\hline
\end{tabular}


Table XXVI. Deficiencies Attributed to Conflicting Procedural Guidance (numbering scheme explained in Appendix E).

\begin{tabular}{||l|l|l|l|l|l||}
\hline \multicolumn{2}{|c|}{1991} & \multicolumn{2}{c|}{1992} & \multicolumn{1}{c||}{1993} & \\
\hline Deficiencies & $\begin{array}{l}\text { Deficiencies } \\
\text { Fixed }\end{array}$ & Deficiencies & $\begin{array}{l}\text { Deficiencies } \\
\text { Fixed }\end{array}$ & Deficiencies & $\begin{array}{l}\text { Deficiencies } \\
\text { Fixed }\end{array}$ \\
\hline \hline DR 131 & YA-92-01-1 & CAR-92-057 & & CAR-93-049 & YA-93-11-1 \\
DR 136 & YA-91-03-6 & CAR-92-058 & & CAR-93-050 & 93-04-03 \\
DR 139 & YA-91-03-8 & CAR-92-018 & & CAR-93-051 & \\
DR 141 & YA-91-03-1 & DR 210 & & DR 226 & \\
DR 142 & $91-001-2$ & DR 211 & & DR 218 & \\
DR 147 & $91-001-4$ & DR 199 & & DR 221 & \\
DR 153 & $91-002-1$ & DR 212 & & DR 222 & \\
DR 159 & $91-002-2$ & & & DR 232 & \\
DR 157 & $91-006-1$ & & & & \\
DR 160 & & & & & \\
DR 163 & & & & & \\
DR 164 & & & & & \\
DR 165 & & & & & \\
DR 169 & & & & & \\
DR 168 & & & & & \\
CAR-91-041 & & & & & \\
SWO-LA-05 & & & & & \\
SWO-LA-06 & & & & & \\
SWO-LA-07 & & & & & \\
CAR-92-002 & & & & & \\
CAR-92-001 & & & & & \\
CAR-92-003 & & & & & \\
DR 167 & & & & & \\
DR 169 & & & & & \\
DR 172 & & & & & \\
DR 187 & & & & & \\
DR 190 & & & & & \\
DR 194 & & & & & \\
DR 189 & & & & & \\
\hline \hline
\end{tabular}


Table XXVII. Deficiencies Attributed to Oversight (numbering scheme explained in Appendix E).

\begin{tabular}{|c|c|c|c|c|c|}
\hline \multicolumn{2}{|r|}{1991} & \multicolumn{2}{|l|}{1992} & \multicolumn{2}{|l|}{1993} \\
\hline Deficiencies & $\begin{array}{l}\text { Deficiencies } \\
\text { Fixed }\end{array}$ & Deficiencies & $\begin{array}{l}\text { Deficiencies } \\
\text { Fixed }\end{array}$ & Deficiencies & $\begin{array}{l}\text { Deficiencies } \\
\text { Fixed }\end{array}$ \\
\hline $\begin{array}{l}\text { DR } 129 \\
\text { DR } 130 \\
\text { DR } 142 \\
\text { DR } 145 \\
\text { DR } 153 \\
\text { DR } 146 \\
\text { DR } 157 \\
\text { DR } 162 \\
\text { DR } 170 \\
\text { DR } 171 \\
\text { DR } 174 \\
\text { DR } 177 \\
\text { DR } 178 \\
\text { DR } 179 \\
\text { DR } 182 \\
\text { DR } 183 \\
\text { DR } 186 \\
\text { DR } 187\end{array}$ & $\begin{array}{l}\text {Y}-91-03-3 \\
Y-91-03-5 \\
Y-91-03-4 \\
91-001-1 \\
91-003-3 \\
91-004-2 \\
91-013-1\end{array}$ & $\begin{array}{l}\text { DR } 195 \\
\text { DR 197 } \\
\text { DR 200 } \\
\text { DR } 201 \\
\text { DR } 204 \\
\text { DR } 205 \\
\text { DR } 206 \\
\text { DR } 210 \\
\text { DR 212 } \\
\text { CAR-93-019 }\end{array}$ & $\begin{array}{l}92-001-1 \\
92-001-3 \\
92-002-3 \\
92-002-4 \\
92-003-1 \\
92-004-1 \\
92-004-2 \\
92-004-3 \\
92-006-2 \\
92-006-3 \\
92-006-4 \\
Y-92-19-01 \\
Y-92-19-02 \\
Y-92-19-03 \\
Y-92-19-04 \\
92-10-001 \\
92-17-001 \\
92-08-001\end{array}$ & $\begin{array}{l}\text { DR } 217 \\
\text { DR } 223 \\
\text { DR } 224 \\
\text { DR } 229 \\
\text { DR } 230\end{array}$ & $\begin{array}{l}\text { YA-93-11-02 } \\
\text { YA-93-11-03 } \\
93-12-06 \\
93-02-01 \\
93-02-02 \\
93-09-05 \\
93-04-01 \\
93-04-02 \\
93-09-06 \\
93-12-05 \\
93-06-01 \\
93-06-02 \\
93-07-02 \\
93-10-02 \\
93-09-01 \\
93-12-02 \\
93-12-04 \\
93-09-03 \\
93-10-04\end{array}$ \\
\hline
\end{tabular}

Table XXVIII. Deficiencies Attributed to M\&TE (numbering scheme explained in Appendix E).

\begin{tabular}{||l|l|l|l|l|l||}
\hline \multicolumn{2}{|c|}{1991} & \multicolumn{2}{c|}{1992} & \multicolumn{2}{c|}{1993} \\
\hline Deficiencies & $\begin{array}{l}\text { Deficiencies } \\
\text { Fixed }\end{array}$ & Deficiencies & $\begin{array}{l}\text { Deficiencies } \\
\text { Fixed }\end{array}$ & Deficiencies & $\begin{array}{l}\text { Deficiencies } \\
\text { Fixed }\end{array}$ \\
\hline \hline DR 137 & Bal PN625058 & DR 203 & Bal PN757327 & DR 228 & Bal PN620505 \\
YA-91-03-4 & Bal PN625058 & & & \\
DR 171 & Bal PN625058 & & & & \\
DR 176 & Bal PN608838 & & & & \\
Bal D09584 & & & & \\
Dal PN447337 141 & Wts not listed & & & & \\
\hline
\end{tabular}



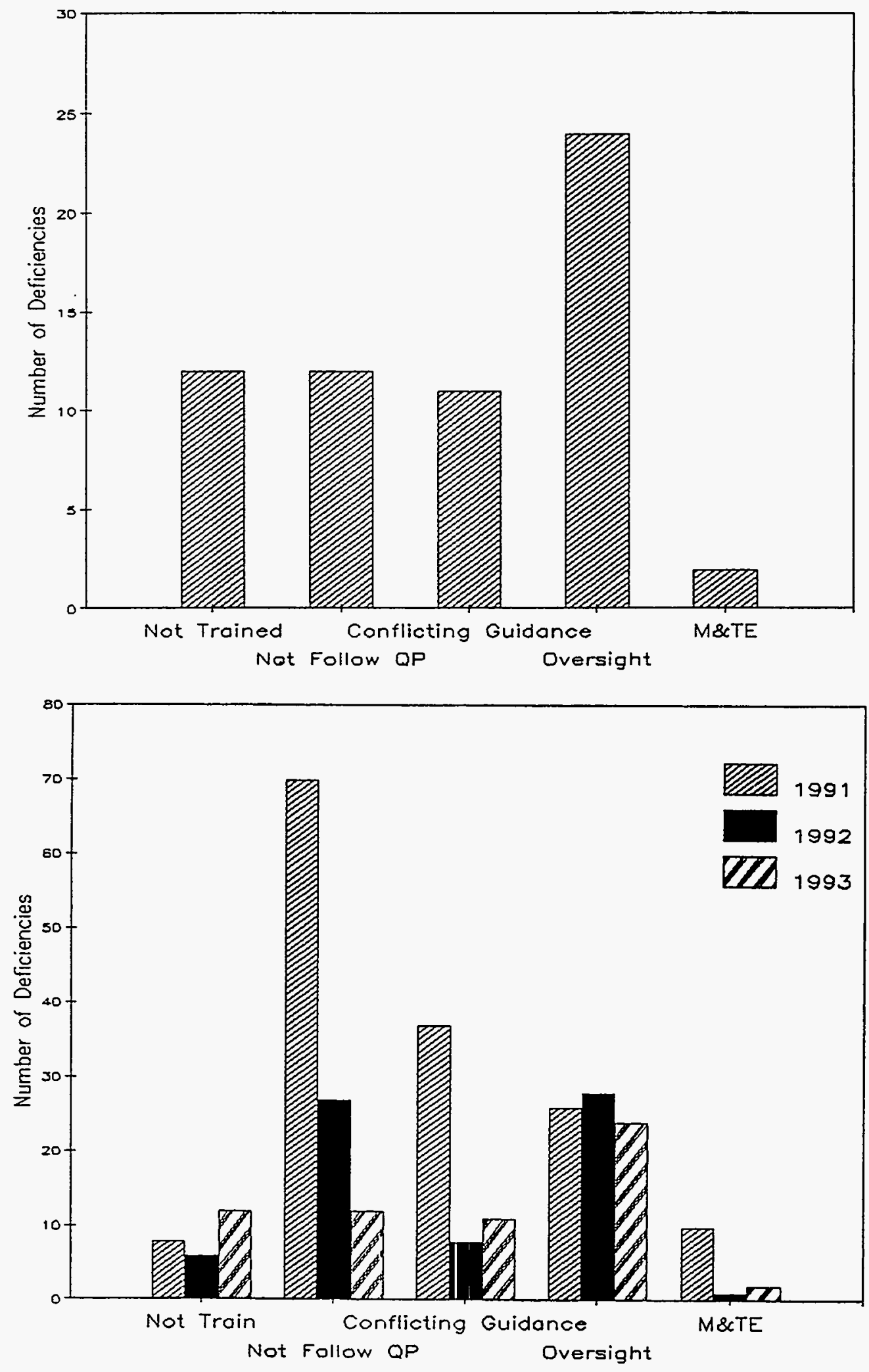

Fig. 6. Deficiencies Assigned to Probable Cause Categories. Top graph shows groupings for 1993. Bottom graph shows data for 1990-1993. 


\subsection{SUMIMARY}

The Los Alamos quality organization, consisting of the contributors to this report, met periodically to discuss and resolve YMP quality issues. Documentation of the results of these meetings are discussed herein. The most important issues addressed were the revision of all quality administrative procedures and formal training classes. These revisions were in response to the new Quality Assurance Requirements and Description (QARD) document, which identifies the quality assurance requirements for the YMP. A new electronic training database was incorporated and a new records management class was developed. We used a matrix to identify where QARD requirements are met in our implementing procedures. This was done in the requirements traceability network database. The new procedures were sent to the DOE in December 1993 for review. Efforts in 1994 will be devoted to resolving the DOE comments. Program development activities in 1994 may require minor changes to these procedures.

Verification activities have helped the quality organization identify specific problems in the Los Alamos YMP. These problems are addressed as resolution to deficiencies issued as part of internal or DOE verification activities. The number of deficiency reports issued in 1993 was seventeen. The number of deficiencies issued since 1987 continues to decrease annually.

Trend analysis reports were issued quarterly in 1993 and the results are summarized here. In an effort to show comparisons of relative compliance to regulations, without consideration to scope or complexity of work, the summary includes comparisons between Participants with respect to issued corrective action reports. When the number of corrective action reports issued by the DOE is examined, the number issued to the Los Alamos YMP quality program is minimal compared to the number of corrective action reports issued to other participants. Los Alamos had no open corrective action reports at the end of 1993.

The Los Alamos YMP, as characterized in this report, is performing satisfactory work for the Yucca Mountain Site Characterization Project. The total number of deficiencies issued during DOE and Los Alamos audit and survey activities are decreasing over time, which shows that Los Alamos personnel are satisfactorily meeting quality assurance requirements.

\subsection{REFERENCES}

Bolivar, S.L., 1992, Los Alamos National Laboratory Yucca Mountain Site Characterization Project 1991 Quality Program Status Report, Los Alamos National Laboratory Report LA-12344-MS, 113p.

Bolivar, S.L., 1994, Los Alamos National Laboratory Yucca Mountain Site Characterization Project 1992 Quality Program Status Report, Los Alamos National Laboratory Report LA-12703-SR, 126p.

Bolivar, S.L., and J.I. Day, 1993, The Quality Assurance Liaison: Combined Technical and Quality Assurance Support, 17th Annual Rocky Mountain Quality Conference Proceedings, Denver, CO., pp. 97-104.

Bolivar, S.L., and M. Finney, 1993, The Quality Connection (Jan. and Sept. issues).

Environmental Safety Services (M. Pope compiler), 1993, LANL Yucca Mountain Project Technical Reference Guide for the Babytrex Database Utilities, Preliminary Draft, 83p. 
LATA, January 1994a (A. Anthony compiler), Orientation to the Los Alamos National Laboratory Yucca Mountain Site Characterization Project, Instructor's Guide (7 modules).

LATA, January 1994b (A. Anthony compiler), Orientation to the Los Alamos National Laboratory Yucca Mountain Site Characterization Project, Participant's Guide (7 modules plus attachments).

Reese, L. (Team Leader), 1993, Los Alamos National Laboratory Yucca Mountain Site Characterization Project Quality Assurance Management Assessment \#93-07 (August 31, 1993), 6p.

U.S. Department of Energy Office of Civilian Radioactive Waste Management, 1993, Office of Quality Assurance Evaluation of OCRWM and Other Affected Organizations Quality Assurance Programs FY-1993, Informal Report dated 11-24-93, 27p.

\section{ACKNOWLEDGMENTS}

Special thanks to J. Atencio, S. Klein, M. Espinosa, and E. Martinez for help in preparation of this document. This work was supported by the Yucca Mountain Site Characterization Project as part of the Civilian Radioactive Waste Management Program. The YMP is managed by the U.S.

Department of Energy, Yucca Mountain Site Characterization Project. This report is not governed by the QARD. It does not introduce any new data, only summarizes previous activities. 
Appendix A

Q Team Charter 
Attendees: The meeting is open to any Laboratory employee (including contractors) who works on the Yucca Mountain Site Characterization Project. Representatives of the following groups are considered charter members and normally will attend every meeting:

\author{
QPO Liaison \\ Verification \\ Records \\ Document Control \\ Management (QAPL) \\ Training \\ Site Research (QALs) \\ DR Coordinator \\ M\&TE Coordinator \\ TCO Office \\ Software Quality Assurance
}

Meetings: Meetings are held on a quarterly basis (four per year) or as needed.

Format: The Quality Assurance Project Leader convenes and presides over the meetings. The agenda is determined by the members.

Purpose: Q meetings are held for the sole purpose of facilitating communication of YMP business. This includes identifying issues of importance to Los Alamos and contractor personnel resolving such issues when possible or notifying the proper personnel (such as management), and providing advisement and planning on such issues when appropriate. By the nature of the business conducted, these meetings provide stress relief and enhance team building. 
Appendix B

Training Classes Provided in 1993 
Table B-1. Formal training classes offered in 1993.

\begin{tabular}{|c|c|c|}
\hline Class & Date & Attendees \\
\hline Orientation & $2-25-93$ & 23 \\
\hline Records Management & $9-14-93$ & 10 \\
\hline Audit Training & $2-93 ; 5-93 ; 7-93$ & 8 \\
\hline
\end{tabular}




\section{Appendix C}

\section{Software Management Status Reports}


Appendix C- Explanation

Following are five reports that summarize the status of the software development and certification effort through December, 1993. The SCR Status Accounting Report lists all of the Software Change Requests (SCRs) that have been received through the reporting month indicated in the title. It specifies all requests for development or certification that have been registered with the SCM organization. The SIR Status Accounting Report provides similar information regarding Software Incident Reports, or bug reports. The ECD Status Accounting Report lists the Engineering Change Directives (ECDs) that have been issued by the Configuration Control Board through the reporting month and indicate the associated SCRs and SIRs. The ECN Status accounting Report lists all Engineering Change Notices (ECNs) for software applications that have been approved for use through the reporting month. To apply one of these codes to activities governed by the QARD, it must be registered with the SCM Organization by submitting a Software/Data Dissemination Request (SDDR). The SDDR Status Accounting Report lists all software registrations to date. 
SCR STATUS ACCOUNTING FOR FOURTH QUARTER 1993

\begin{tabular}{|c|c|c|c|c|}
\hline ID & SUBJECT & REQUESTOR & DATE & ECD \\
\hline 1 & Certification of DIFFRAC5000 Version 2.2 & Steve Chipera & $02 / 04 / 91$ & 1 \\
\hline 2 & Certification of SHELXTL PLUS Version 4.11 & Steve Chipera & $02 / 04 / 91$ & 2 \\
\hline 3 & Certification of VAX-PRD2/CDIF Version 1.04 & Steve Chipera & $02 / 04 / 91$ & 3 \\
\hline 4 & Certification of PL Thermal MAIN PACKAGE 4.30 & Steve Chipera & $02 / 04 / 91$ & 4 \\
\hline 5 & Conversion of Pre-existing Software TRACRN & Lynn Trease & $02 / 04 / 91$ & 5 \\
\hline 6 & Certification of VMS & David Cruze & $02 / 04 / 91$ & 6 \\
\hline 7 & Certification of INGRES (6.3) & David Cruzé & $02 / 04 / 91$ & 7 \\
\hline 8 & Certification of INGRES/Windows 4GL (6.0) & David Cruze & $02 / 04 / 91$ & 8 \\
\hline 9 & Qualification of Minfile Version 3.88 & Barbara Carlos & $02 / 04 / 91$ & 14 \\
\hline 11 & Qualification of DCS EM4105 Version 3.51-1.40 & Barbara Carlos & $02 / 04 / 91$ & 16 \\
\hline 12 & Establish CCB Meeting Standards & David Cruze & $02 / 08 / 91$ & 0 \\
\hline 13 & Develop Standards for File Lists & Gary Cort & $02 / 08 / 91$ & 9 \\
\hline 14 & Develop FORTRAN Standards & Gary Cort & $02 / 08 / 91$ & 10 \\
\hline 15 & Qualify Unix Operating Systems & Donn Hines & $02 / 08 / 91$ & 11 \\
\hline 16 & Qualify NetCDF Software & Donn Hines & $02 / 08 / 91$ & 12 \\
\hline 17 & Develop Interface Table Utilities & Donn Hines & $02 / 08 / 91$ & 13 \\
\hline 18 & Qualification of Dionex AI-450 Version 2.1 & Brent Nerwman & $02 / 08 / 91$ & 17 \\
\hline 19 & Qualification of IBM DOS 3.30 Operating System & Brent Newman & $02 / 08 / 91$ & 18 \\
\hline 20 & Qualification of Microsoft Windows Version 2.0 & Brent Newman & $02 / 08 / 91$ & 19 \\
\hline 21 & Development and Certification of SORBEQ & Bruce Robinson & $02 / 11 / 91$ & 20 \\
\hline 22 & Certification of Existing Code FRACNET & Bruce Robinson & $02 / 11 / 91$ & 21 \\
\hline 23 & Certification ü Existing Code BE:Huilv & Bruce Sivisinso: & $62 ; i_{i j}=i$ & 22 \\
\hline 24 & Develop A Generalized Plotting Routine & Zora Dash & $02 / 19 / 91$ & 23 \\
\hline 25 & Develop Interface Table I/O Handling Routines & Zura Dash & $02 / 19 / 91$ & 24 \\
\hline 29 & Certification of CEO-CALC PTA Version 1.0 & Steve Chipera & $02 / 14 / 91$ & 29) \\
\hline
\end{tabular}


SCR STATUS ACCOUNTING FOR FOURTH QUARTER 1993

\begin{tabular}{|c|c|c|c|c|}
\hline ID & SUBJECT & REQUESTOR & DATE & ECD \\
\hline 30 & Certification of GEO-CALC PTX Version 1.0 & Steve Chipera & $02 / 14 / 91$ & 29 \\
\hline 31 & Certification of VACCELERATOR Version 3.10 & Steve Chipera & $02 / 14 / 91$ & 30 \\
\hline 32 & Certification of GSAS (10-JAN-1991 distribution) & Steve Chipera & $02 / 14 / 91$ & 31 \\
\hline 33 & Certification of DPLOTF Version 060986 & Steve Chipera & $02 / 14 / 91$ & 0 \\
\hline 34 & Certification of XRDPLT Version 870702 & Steve Chipera & $02 / 14 / 91$ & 32 \\
\hline 35 & Certification of QUANT Version 5.2 & Steve Chipera & $02 / 14 / 91$ & 33 \\
\hline 36 & Certification of SEDIT Version 900606 & Steve Chipera & $02 / 14 / 91$ & 34 \\
\hline 37 & Certification of GRAPHINT Version 900813 & Steve Chipera & $02 / 14 / 91$ & 35 \\
\hline 38 & Certification of GETSIEM Version 900717 & Steve Chipera & $02 / 14 / 91$ & 36 \\
\hline 39 & Certification of SIEMPUT Version 900604 & Steve Chipera & $02 / 14 / 91$ & 36 \\
\hline 40 & Certify Macintosh Operating System & Gary Cort & $02 / 20 / 91$ & 37 \\
\hline 41 & Certify HyperCard Application & Gary Cort & $02 / 20 / 91$ & 38 \\
\hline 42 & Certify Softool CCC Database & Gary Cort & $02 / 20 / 91$ & 39 \\
\hline 43 & Certify 4 th Dimension & Gary Cort & $02 / 20 / 91$ & 40 \\
\hline 44 & Certify' DISSPLA Version 11.0 Graphics Package & Zora Dash & $02 / 19 / 91$ & 25 \\
\hline 45 & Certification of RS/ 1 Version 4.3 & Gary Luedemann & $02 / 20 / 91$ & 41 \\
\hline 46 & Certification of NCSA Image Version 2.0 & Eric Nuttall & $02 / 17 / 91$ & 42 \\
\hline 47 & Certification of Existing Code CTCN & Eric Nuttall & $02 / 27 / 91$ & 43 \\
\hline 48 & Certification of Existing Code LSODPK & Eric Nuttall & $02 / 27 / 91$ & 44 \\
\hline 49 & $\begin{array}{c}\text { Develop Standards for CCC Database Macro } \\
\text { Language }\end{array}$ & Gary Cort & $03 / 06 / 91$ & 45 \\
\hline 51 & Certify Spyglass Software for the Macintosh & Lynn McDonald & $03 / 14 / 91$ & 47 \\
\hline 53 & Qualification of Microsoft C (Version 5.0) & Scott Carpenter & $03 / 25 / 91$ & 49 \\
\hline 54 & Qualification of Nucleus PCA 4000 (Version 880104) & Scott Carpenter & $03 / 25 / 91$ & 50 \\
\hline 55 & Qualification of Microsoft FORTRAN (Version 5.0) & Scott Carpenter & $03 / 25 / 91$ & 51 \\
\hline 56 & $\begin{array}{c}\text { Qualification of Microsoft GW-BASIC (Ver } \\
\text { 2.(12,Release A.2) }\end{array}$ & Scott Carpenter & $03 / 25 / 91$ & 52 \\
\hline
\end{tabular}


SCR STATUS ACCOUNTING FOR FOURTH QUARTER 1993

\begin{tabular}{|c|c|c|c|c|}
\hline ID & SUBJECT & REQUESTOR & DATE & ECD \\
\hline 57 & Qualification of SIGMAPLOT (Version 4.0) & Scott Carpenter & $03 / 25 / 91$ & 53 \\
\hline 65 & Qualification of COBRA Control Software & Alan Mitchell & $03 / 22 / 91$ & 54 \\
\hline 66 & Qualification of Mathematica 386/7 (Version 1.2) & Ines Triay & $03 / 22 / 91$ & 55 \\
\hline 67 & Qualification of TMENU Backup Software & Ines Triay & $03 / 22 / 91$ & 56 \\
\hline 68 & Qualification of Microsoft Excel for Windows & Ines Triay & $03 / 22 / 91$ & 57 \\
\hline 69 & Qualification of Lotus 1-2-3 (Release 2.01 and 3.0) & Ines Triay & $03 / 22 / 91$ & 58 \\
\hline 70 & Qualification of Microsoft DOS (Version 3.3) & Ines Triay & $03 / 22 / 91$ & 59 \\
\hline 71 & Qualification of BI-2030 AT Control Software & Alan Mitchell & $03 / 22 / 91$ & 60 \\
\hline 72 & Qualification of Microsoft Quick BASIC (Version 3.0) & Alan Mitchell & $03 / 22 / 91$ & 61 \\
\hline 73 & $\begin{array}{c}\text { Qualification of DM 3000F (Version 2.5) Control } \\
\text { Software }\end{array}$ & Ines Triay & $03 / 22 / 91$ & 62 \\
\hline 75 & Qualification of Tri-Carb 2500TR Control Software & Alan Mitchell & $03 / 22 / 91$ & 64 \\
\hline 78 & Qualification of Noran Instrument's ADEM (3.0) & Peg Snow & $04 / 09 / 91$ & 65 \\
\hline 79 & Qualification of Noran Instrument's VISTA Software & Peg Snow & $04 / 09 / 91$ & 66 \\
\hline 80 & Develop ASCII-to-NetCDF Data Conversion Tool & Bruce Robinson & $04 / 15 / 91$ & 74 \\
\hline 81 & Qualification of SCALE.BAS & Gary Luedemann & $04 / 16 / 91$ & 80 \\
\hline 82 & Qualification of Rigaku's ESCP & Gary Luedemann & $04 / 16 / 91$ & 75 \\
\hline 83 & Qualification of Rigaku's DataFlex 360 & Gary Luedemann & $04 / 16 / 91$ & 76 \\
\hline 84 & Qualification of Microsoft's QuickBASIC 4.5 & Gary Luedemann & $04 / 16 / 91$ & 0 \\
\hline 85 & Programming Standards for QuickBASIC & David Morris & $04 / 23 / 91$ & 77 \\
\hline 86 & Instrument Control Software for PAS System & David Morris & $05 / 02 / 91$ & 81 \\
\hline 87 & Qualification of Cricket Graph Software & David Morris & $05 / 02 / 91$ & 82 \\
\hline 88 & Qualification of IGOR Software & David Morris & $05 / 02 / 91$ & 83 \\
\hline 89 & Qualification of IOTech/IEEE Controllers & David Morris & $05 / 02 / 91$ & 84 \\
\hline 90 & Qualification of Microsoft QuickBASIC & David Morris & $05 / 02 / 91$ & 85 \\
\hline 91 & $\begin{array}{l}\text { Qualify Ultrix DEC Fortran and VMS Fortran } \\
\text { Compilers }\end{array}$ & Donn Hines & $05 / 23 / 91$ & 86 \\
\hline
\end{tabular}


SCR STATUS ACCOUNTING FOR FOURTH QUARTER 1993

\begin{tabular}{|c|c|c|c|c|}
\hline ID & SUBJECT & REQUESTOR & DATE & ECD \\
\hline 92 & Qualify Ultrix and VMS C Compilers & Donn Hines & $05 / 23 / 91$ & 87 \\
\hline 93 & Qualification of Sandia TASK8 Software & M.G. Snow & $05 / 29 / 91$ & 88 \\
\hline 94 & Qualification of Tracor Northern 'IDENT' software & M. G. Snow & $05 / 29 / 91$ & 89 \\
\hline 95 & Qualification of Tracor Northern 'SQ' Software & M. G.Snow & $05 / 29 / 91$ & 90 \\
\hline 96 & Qualification of PlanPerfect & Ines Triay & 06/06/91 & 91 \\
\hline 97 & Programming Standards for ADA & Robert Kelsey & $06 / 10 / 91$ & 92 \\
\hline 102 & Certification of existing code GZSOLVE & Bruce Robinson & $07 / 11 / 91$ & 97 \\
\hline 105 & Qualification of Peakfit & Emerson Tongco & $07 / 31 / 91$ & 100 \\
\hline 106 & Qualify Meridian and Digital Ada Compilers & Robert Kelsey & $08 / 02 / 91$ & 102 \\
\hline 107 & CLAMS & Emerson Tongco & $08 / 05 / 91$ & 103 \\
\hline 108 & Qualification of "OS-9" Operating System & M. G.Snow & $08 / 28 / 91$ & 104 \\
\hline 109 & Qualification of "FLEX" Operating System & M. G.Snow & $08 / 28 / 91$ & 105 \\
\hline 110 & Qualification Excel for the Macintosh & David Broxton & $08 / 30 / 91$ & 106 \\
\hline 111 & Qualification of Versa Term-Pro & David Broxton & $08 / 30 / 91$ & 107 \\
\hline 112 & Qualification of KaleidaGraph & David Broxton & $08 / 30 / 91$ & 108 \\
\hline 113 & Structured Language Standards & Donn Hines & $09 / 10 / 91$ & 109 \\
\hline 114 & Shell Script Standards & Donn Hines & $09 / 10 / 91$ & 110 \\
\hline 115 & DCL Standards & Donn Hines & $09 / 10 / 91$ & 111 \\
\hline 116 & CSA Database Upgrade & Steve Donahue & $10 / 03 / 91$ & 115 \\
\hline 117 & Qualification of digiMatic & David Broxton & $10 / 10 / 91$ & 116 \\
\hline 118 & Project Schedule Update Mailer & Gary Cort & $10 / 11 / 91$ & 118 \\
\hline 119 & Ada Character String Utilities & Gary Cort & $10 / 11 / 91$ & 119 \\
\hline 121 & Documentation Generation Tool & Donn Hines & $10 / 25 / 91$ & 122 \\
\hline 122 & Certification of NierGas Application & Jane Poths & $10 / 29 / 91$ & 123 \\
\hline 123 & Ada Conclition Notification Facility & Gary Cort & $10 / 30 / 91$ & 124 \\
\hline 124 & Qualification of Microsoft QuickBASIC Toolbox & Gary Luedemann & $10 / 21 / 91$ & 125 \\
\hline
\end{tabular}


SCR STATUS ACCOUNTING FOR FOURTH QUARTER 1993

\begin{tabular}{|c|c|c|c|c|}
\hline ID & SUBJECT & REQUESTOR & DATE & ECD \\
\hline 125 & Qualification of SAS for SunX & Brent Newman & $11 / 15 / 91$ & 126 \\
\hline 126 & Upgrade the Computer Program Library & Steve Donahue & $11 / 21 / 91$ & 128 \\
\hline 127 & Qualification of K/Ar Control Software & Giday WoldeGabriel & $11 / 27 / 91$ & 129 \\
\hline 128 & Update Standards Documents & Steve Donahue & $12 / 05 / 91$ & 130 \\
\hline 129 & Certify Surface Display System for the IBM PC & Bruce Crowe & $12 / 11 / 91$ & 131 \\
\hline 130 & Certification of AXUM for the IBM PC & Bruce Crowe & $12 / 11 / 91$ & 132 \\
\hline 131 & Certification of SYSTAT for the IBM PC & Bruce Crowe & $12 / 11 / 91$ & 133 \\
\hline 132 & Standardize Build Filename Extensions ${ }^{-}$ & Steve Dönahue & $02 / 10 / 92$ & 134 \\
\hline 133 & Certification of CENTX & Brent Newman & $02 / 25 / 92$ & 135 \\
\hline 134 & COHORT Software Package & Brent Newman & $03 / 01 / 92$ & 146 \\
\hline 135 & Certification of GEO PLUS & M. G.Snow & $03 / 09 / 92$ & 141 \\
\hline 136 & Certification of SXRAY/SUN & M. G. Snow & $03 / 09 / 92$ & 137 \\
\hline 137 & Certification of VISILOG & M. G. Snow & $03 / 09 / 92$ & 138 \\
\hline 138 & Certification of CIAP & M. G.Snow & $03 / 09 / 92$ & 139 \\
\hline 139 & Certification of FCIAP & M. G. Snow & $03 / 09 / 92$ & 140 \\
\hline 140 & Certification of SUN/TOPS & M. G. Snow & $03 / 09 / 92$ & 142 \\
\hline 141 & Certification of MAC/TOPS & M. G.Snow & $03 / 09 / 92$ & 143 \\
\hline 142 & Certification of IMIX & M. G.Snow & $03 / 09 / 92$ & 144 \\
\hline 143 & Certify Unix Operating System & Steve Donahue & $03 / 12 / 92$ & 147 \\
\hline 144 & Certify FORTRAN compilers & Steve Donahue & $03 / 12 / 92$ & 148 \\
\hline 145 & Standardize Make File Extensions & Steve Donahue & $03 / 13 / 92$ & 134 \\
\hline 146 & Certification of Tecplot for the Sun Workstation & Lynn McDonald & $03 / 13 / 92$ & 150 \\
\hline 147 & Certification of The Data Visualizer & Lynn McDonald & $03 / 13 / 92$ & 151 \\
\hline 148 & Certification of AVS Software & Lynn McDonald & $03 / 13 / 92$ & 152 \\
\hline 149 & BIO-RAD Software Package & Steve Chipera & $03 / 12 / 92$ & 155 \\
\hline 150 & COREL DRAW Version 2.01 & Steve Chipera & $03 / 12 / 92$ & 156 \\
\hline
\end{tabular}


SCR STATUS ACCOUNTING FOR FOURTH QUARTER 1993

\begin{tabular}{|c|c|c|c|c|}
\hline ID & SUBJECT & REQUESTOR & DATE & ECD \\
\hline 151 & Certification of Wildsoft Surveying System Software & Bruce Crowe & $02 / 24 / 92$ & 157 \\
\hline 152 & SPECTRALAB PC & Steve Chipera & $03 / 12 / 92$ & 158 \\
\hline 153 & Postsoft Version 1.0 & Steve Chipera & $03 / 12 / 92$ & 159 \\
\hline 154 & PIZAZZ PLUS & Steve Chipera & $04 / 02 / 92$ & 160 \\
\hline 155 & LCLSQ & Steve Chipera & $03 / 27 / 92$ & 161 \\
\hline 156 & TGRAF & Steve Chipera & $03 / 27 / 92$ & 162 \\
\hline 157 & TABLECURVE & Steve Chipera & $03 / 23 / 92$ & 153 \\
\hline 158 & DIFFRACTINEL & Steve Chipera & $03 / 23 / 92$ & 154 \\
\hline 159 & Nanoscope III & Marilyn Hawley & $04 / 09 / 92$ & 163 \\
\hline 160 & Certification of Chaos & Bruce Crowe & $04 / 09 / 92$ & 164 \\
\hline 161 & Certification of Quattro Pro & Bruce Crowe & $04 / 09 / 92$ & 165 \\
\hline 162 & Certification of Non-Linear Forecasting & Bruce Crowe & $04 / 09 / 92$ & 166 \\
\hline 163 & Certification of MathCad & Bruce Crowe & $04 / 09 / 92$ & 167 \\
\hline 164 & Certification of IGPET & Bruce Crowe & $04 / 09 / 92$ & 168 \\
\hline 165 & Certification of Designer & Bruce Crowe & $04 / 09 / 92$ & 169 \\
\hline 166 & NLINISO.SAS & Brent Newman & $04 / 28 / 92$ & 166 \\
\hline 167 & PKZip Archive Utility & Brent Newman & $07 / 14 / 92$ & 170 \\
\hline 168 & Certification of Surfer & Bruce Crowe & $09 / 30 / 92$ & 173 \\
\hline 169 & XRFDRVOX & Gary Luedemann & $11 / 13 / 92$ & 174 \\
\hline 170 & Development of NONLIN_LSQ Application & Bruce Robinson & $01 / 12 / 93$ & 175 \\
\hline 171 & Certification of STATISTICA & Pamela Rogers & $01 / 14 / 93$ & 176 \\
\hline 172 & Update of QUANT & Steve Chipera & $01 / 25 / 93$ & 177 \\
\hline 173 & Certification of At Risk & Bruce Crowe & $\mathbf{n} / 0.3 / 93$ & 180 \\
\hline 174 & Certification of Crystal Ball for Windows & Bruce Crowe & $03 / 03 / 93$ & 181 \\
\hline 175 & Certification of Statistical Navigator & Bruce Crowe & $03 / 03 / 93$ & 182 \\
\hline 176 & Certification of PATASC & Steve Chipera & $02 / 26 / 93$ & 178 \\
\hline
\end{tabular}


SCR STATUS ACCOUNTING FOR FOURTH QUARTER 1993

\begin{tabular}{|c|c|c|c|c|}
\hline ID & SUBJECT & REQUESTOR & DATE & ECD \\
\hline \hline .177 & Certification of SiemGetPut & Steve Chipera & $02 / 26 / 93$ & 179 \\
\hline 178 & Fox Pro & Richard Morley & $03 / 17 / 93$ & 183 \\
\hline 179 & Certify XRF-11 & Emily Kluk & $06 / 18 / 93$ & 184 \\
\hline 180 & Certification of NEWMODF Application & Steve Chipera & $07 / 01 / 93$ & 185 \\
\hline 181 & Certification of dBase IV & Andrew Burningham & $08 / 10 / 93$ & 186 \\
\hline
\end{tabular}


SIR STATUS ACCOUNTING FOR FOURTH QUARTER 1993

\begin{tabular}{|c|c|c|c|c|}
\hline ID & SUBJECT & REQUESTOR & DATE & $\begin{array}{c}\text { ECD } \\
\text { No }\end{array}$ \\
\hline 1 & Error in Fortran Standards (ECD-10) & Emerson Tongco & $07 / 31 / 91$ & 101 \\
\hline 2 & Error in Fortran Standards (ECD-10) & Robert Kelsey & $07 / 31 / 91$ & 101 \\
\hline 3 & FORTRAN STANDARDS & Emerson Tongco & $08 / 06 / 91$ & 101 \\
\hline 4 & INTERFACE_TABLES Design Problems & Donn Hines & $11 / 15 / 91$ & 127 \\
\hline 5 & Ada Condition Notification & Steve Donahue & $02 / 19 / 92$ & 149 \\
\hline 6 & Interface Tables Test Script Program & Steve Donahue & $02 / 21 / 92$ & 136 \\
\hline 7 & Interface Tables Test Script Program & Steve Donahue & $02 / 21 / 92$ & 136 \\
\hline 8 & Missing SDD for Interface Tables & Donn Hines & $02 / 27 / 92$ & 136 \\
\hline 9 & INTERFACE_TABLES Requirements & Donn Hines & $03 / 06 / 92$ & 136 \\
\hline 11 & MINFILE Caiculator Error & Barbara Carlos & $04 / 10 / 92$ & 0 \\
\hline 12 & CDFTOOLS Application - Unicos Installation & Zora Dash & $08 / 19 / 92$ & 171 \\
\hline
\end{tabular}


ECD STATUS ACCOUNTING FOR FOURTH QUARTER 1993

\begin{tabular}{|c|c|c|c|}
\hline ID & DATE & SUBJECT & DEVELOPER \\
\hline 1 & $02 / 08 / 91$ & Certification of DIFFRAC5000 Version 2.2 & Steve Chipera \\
\hline 2 & $02 / 08 / 91$ & Certification of SHELXTL Plus Version 4.11 & Steve Chipera \\
\hline 3 & $02 / 08 / 91$ & $\begin{array}{c}\text { Certification of VAX-PRD2/CDIF Version } \\
1.04\end{array}$ & Steve Chipera \\
\hline 4 & $02 / 08 / 91$ & $\begin{array}{l}\text { Certification of PL Thermal MAIN } \\
\text { PACKAGE } 4.30\end{array}$ & Steve Chipera \\
\hline 5 & $02 / 08 / 91$ & $\begin{array}{c}\text { Conversion of Pre-existing Software } \\
\text { TRACRN }\end{array}$ & Lynn Trease \\
\hline 6 & $02 / 08 / 91$ & Certification of VMS & David Cruze \\
\hline 7 & $02 / 08 / 91$ & Certification of INGRES (6.3) & David Cruze \\
\hline 8 & $02 / 08 / 91$ & $\begin{array}{l}\text { Certification of INGRES/Windows 4GL } \\
\qquad(6.0)\end{array}$ & David Cruze \\
\hline 9 & $02 / 08 / 91$ & Develop Standards for File Lists & Gary Cort \\
\hline 10 & $02 / 08 / 91$ & Develop FORTRAN Standards & Gary Cort \\
\hline 11 & $02 / 08 / 91$ & Qualify Unix Operating Systems & Donn Hines \\
\hline 12 & $02 / 08 / 91$ & Qualify NetCDF Software & Donn Hines \\
\hline 13 & $02 / 08 / 91$ & Develop Interface Table Utilities & Donn Hines \\
\hline 14 & $02 / 19 / 91$ & Qualification of Minfile Version 3.88 & Barbara Carlos \\
\hline 16 & $02 / 19 / 91$ & $\begin{array}{l}\text { Qualification of DCS EM4105 Version 3.51- } \\
\qquad 1.40\end{array}$ & Barbara Carlos \\
\hline 17 & $02 / 19 / 91$ & Qualification of Dionex AI-450 Version 2.1 & $\begin{array}{c}\text { Brent } \\
\text { Newman }\end{array}$ \\
\hline 18 & $02 / 19 / 91$ & $\begin{array}{c}\text { Qualification of IBM DOS 3.30 Operating } \\
\text { System }\end{array}$ & $\begin{array}{c}\text { Brent } \\
\text { Newman }\end{array}$ \\
\hline 19 & $02 / 19 / 91$ & $\begin{array}{c}\text { Qualification of Microsoft Windows } \\
\text { Version } 2.0\end{array}$ & $\begin{array}{c}\text { Brent } \\
\text { Newman }\end{array}$ \\
\hline 20 & $02 / 19 / 91$ & Development and Certification of SORBEQ & $\begin{array}{l}\text { Bruce } \\
\text { Robinson }\end{array}$ \\
\hline 21 & $02 / 19 / 91$ & Certification of Existing Code FRACNET & $\begin{array}{l}\text { Bruce } \\
\text { Robinson }\end{array}$ \\
\hline 22 & $06 / 01 / 93$ & FEHMN Application & Zora Dash \\
\hline 23 & $03 / 04 / 91$ & Develop A Generalized Plot Routine & Zura Dash \\
\hline
\end{tabular}


ECD STATUS ACCOUNTING FOR FOURTH QUARTER 1993

\begin{tabular}{|c|c|c|c|}
\hline ID & DATE & SUBJECT & DEVELOPER \\
\hline 24 & $03 / 04 / 91$ & $\begin{array}{c}\text { Develop Interface Table I/O Handling } \\
\text { Routines }\end{array}$ & Zora Dash \\
\hline 25 & $03 / 04 / 91$ & $\begin{array}{c}\text { Certify DISSPLA Version } 11.0 \text { Graphics } \\
\text { Package }\end{array}$ & Zora Dash \\
\hline 29 & $03 / 04 / 91$ & Certification of GEO-CALC PTA and PTX & Steve Chipera \\
\hline 30 & $03 / 04 / 91$ & $\begin{array}{l}\text { Certification of VACCELERATOR Version } \\
\qquad 3.10\end{array}$ & Steve Chipera \\
\hline 31 & $03 / 04 / 91$ & $\begin{array}{c}\text { Certification of GSAS (10-JAN-1991 } \\
\text { distribution) }\end{array}$ & Steve Chipera \\
\hline 33 & $03 / 04 / 91$ & Certification of QUANT Version 5.2 & Steve Chipera \\
\hline 35 & $03 / 04 / 91$ & Certification of GRAPHINT Version 900813 & Steve Chipera \\
\hline 36 & $03 / 04 / 91$ & Certification of GETSIEM and SIEMPUT & Steve Chipera \\
\hline 37 & $03 / 04 / 91$ & Certify Macintosh Operating System & Gary Cort \\
\hline 38 & $03 / 04 / 91$ & Certify HyperCard Application & Gary Cort \\
\hline 39 & $03 / 04 / 91$ & Certify Softool CCC Database & Gary Cort \\
\hline 40 & $03 / 04 / 91$ & Certify 4th Dimension Database & Gary Cort \\
\hline 41 & $03 / 04 / 91$ & Certification of RS/1 Version 4.3 & $\begin{array}{c}\text { Gary } \\
\text { Luedemann }\end{array}$ \\
\hline 42 & $03 / 04 / 91$ & Certification of NCSA's Image Version 2.0 & Eric Nuttall \\
\hline 43 & $03 / 04 / 91$ & Certification of Existing Code CTCN & Eric Nuttall \\
\hline 44 & $03 / 04 / 91$ & Certification of Existing Code LSODPK & Eric Nuttall \\
\hline 45 & $03 / 15 / 91$ & $\begin{array}{c}\text { Develop Standards for CCC Database } \\
\text { Macro Language }\end{array}$ & Gary Cort \\
\hline 47 & $04 / 02 / 91$ & $\begin{array}{l}\text { Certify Spyglass Software for the } \\
\text { Macintosh }\end{array}$ & $\begin{array}{l}\text { Lynn } \\
\text { McDonald }\end{array}$ \\
\hline 49 & $04 / 01 / 91$ & Qualification of Micros oft C (Version 5.0) & $\begin{array}{c}\text { Scott } \\
\text { Carpenter }\end{array}$ \\
\hline 50 & $04 / 01 / 91$ & $\begin{array}{l}\text { Qualification of Nucleus PCA-4000 } \\
\text { (Version 880104) }\end{array}$ & $\begin{array}{c}\text { Scott } \\
\text { Carpenter }\end{array}$ \\
\hline 51 & $(14 / 01 / 91$ & $\begin{array}{c}\text { Qualification of Microsoft FORTRAN } \\
\text { (Version 5.0) }\end{array}$ & $\begin{array}{c}\text { Scott } \\
\text { Carpenter }\end{array}$ \\
\hline 52 & $04 / 01 / 91$ & $\begin{array}{c}\text { Qualification of Microsoft GW-BASIC (Ver } \\
2 .(02, \text { Release A2) }\end{array}$ & $\begin{array}{l}\text { Scott } \\
\text { Carpenter }\end{array}$ \\
\hline
\end{tabular}


ECD STATUS ACCOUNTING FOR FOURTH QUARTER 1993

\begin{tabular}{|c|c|c|c|}
\hline ID & DATE & SUBJECT & DEVELOPER \\
\hline 53 & $04 / 01 / 91$ & Qualification of SIGMAPLOT (Version 4.0) & $\begin{array}{l}\text { Scott } \\
\text { Carpenter }\end{array}$ \\
\hline 54 & $04 / 03 / 91$ & Qualification of COBRA Control System & Alan Mitchell \\
\hline 55 & $04 / 03 / 91$ & $\begin{array}{c}\text { Qualification of Mathematica 386/7 } \\
\text { (Version 1.2) }\end{array}$ & Ines Triay \\
\hline 56 & $04 / 03 / 91$ & Qualification of TMENU Backup Software & Ines Triay \\
\hline 57 & $04 / 03 / 91$ & $\begin{array}{l}\text { Qualification of Microsoft Excel for } \\
\text { Windows (Version 2.1C) }\end{array}$ & Ines Triay \\
\hline 58 & $04 / 03 / 91$ & $\begin{array}{l}\text { Qualification of Lotus 1-2-3 (Release } 2.01 \\
\text { and 3.0) }\end{array}$ & Ines Triay \\
\hline 59 & $04 / 03 / 91$ & $\begin{array}{l}\text { Qualification of Microsoft DOS (Version } \\
\text { 3.3) }\end{array}$ & Ines Triay \\
\hline 60 & $04 / 03 / 91$ & $\begin{array}{c}\text { Qualification of BI-2030 AT Control } \\
\text { Software }\end{array}$ & Alan Mitchell \\
\hline 61 & $04 / 03 / 91$ & $\begin{array}{c}\text { Qualification of Microsoft Quick BASIC } \\
\text { (Version 3.0) }\end{array}$ & Alan Mitchell \\
\hline 62 & $04 / 03 / 91$ & $\begin{array}{c}\text { Qualification of DM 3000F (Version 2.5) } \\
\text { Control Software }\end{array}$ & Alan Mitchell \\
\hline 64 & $04 / 03 / 91$ & $\begin{array}{c}\text { Qualification of Tri-Carb 2500TR Control } \\
\text { Software }\end{array}$ & Alan Mitchell \\
\hline 65 & $04 / 12 / 91$ & $\begin{array}{l}\text { Qualification of Noran Instrument's ADEM } \\
\qquad(3.0)\end{array}$ & Peg Snow \\
\hline 66 & $04 / 12 / 91$ & $\begin{array}{c}\text { Qualification of Noran Instrument's VISTA } \\
\text { Software }\end{array}$ & Peg Snow \\
\hline 74 & $04 / 15 / 91$ & $\begin{array}{c}\text { Develop ASCII-to-NetCDF Data } \\
\text { Conversion Tool }\end{array}$ & $\begin{array}{c}\text { Bruce } \\
\text { Robinson }\end{array}$ \\
\hline 75 & $04 / 22 / 91$ & Qualification of Rigaku's ESCP & $\begin{array}{c}\text { Gary } \\
\text { Luedemmann }\end{array}$ \\
\hline 76 & $04 / 22 / 91$ & Qualification of Rigaku's DataFlex 360 & $\begin{array}{c}\text { Gary } \\
\text { Luedemann }\end{array}$ \\
\hline 77 & $04 / 23 / 91$ & Programming Standards for QuickBASIC & David Morris \\
\hline 81 & $06 / 10 / 91$ & $\begin{array}{c}\text { Instrument Control Software for PAS } \\
\text { System }\end{array}$ & David Morris \\
\hline 82 & $015 / 24 / 91$ & Qualification of Cricket Graph Software & David Morris \\
\hline 83 & $(15 / 24 / 91$ & Qualification of ICOR Software & David Morris \\
\hline
\end{tabular}


ECD STATUS ACCOUNTING FOR FOURTH QUARTER 1993

\begin{tabular}{|c|c|c|c|}
\hline ID & DATE & SUBJECT & DÉVELOPER \\
\hline 84 & $05 / 24 / 91$ & Qualification of 1OTech/IEEE Controllers & David Morris \\
\hline 85 & $05 / 24 / 91$ & Qualification of Microsoft QuickBASIC & David Morris \\
\hline 86 & $05 / 24 / 91$ & $\begin{array}{l}\text { Qualify Ultrix DEC Fortran and VMS } \\
\text { Fortran Compilers }\end{array}$ & Donn Hines \\
\hline 87 & $05 / 24 / 91$ & Qualify Ultrix and VMS C Compilers & Donn Hines \\
\hline 88 & $05 / 29 / 91$ & TASK8 & M. G.Snow \\
\hline 89 & $05 / 29 / 91$ & IDENT & M. G.Snow \\
\hline 90 & $05 / 29 / 91$ & SQ & M. G. Snow \\
\hline 91 & $06 / 07 / 91$ & Qualification of PlanPerfect & Ines Triay \\
\hline 92 & $06 / 10 / 91$ & Programming Standards for ADA & Rob Kelsey \\
\hline 97 & $07 / 12 / 91$ & Qualification of GZSOLVE & $\begin{array}{c}\text { George } \\
\text { Zyvoloski }\end{array}$ \\
\hline 100 & $07 / 31 / 91$ & Qualification of PEAKFIT & $\begin{array}{l}\text { Emerson } \\
\text { Tongco }\end{array}$ \\
\hline 101 & $08 / 01 / 91$ & Fortran Standards & $\begin{array}{l}\text { Steve } \\
\text { Donahue }\end{array}$ \\
\hline 102 & $08 / 02 / 91$ & Ada Compilers & Robert Kelsey \\
\hline 103 & $08 / 06 / 91$ & CLAMS & $\begin{array}{l}\text { Emerson } \\
\text { Tongco }\end{array}$ \\
\hline 104 & $09 / 10 / 91$ & Qualification of OS-9 Operating System & M.G. Snow \\
\hline 105 & $09 / 10 / 91$ & Qualification of FLEX Operating System & M.G.Snow \\
\hline 106 & $09 / 10 / 91$ & Qualification of Excel for Macintosh & David Broxton \\
\hline 107 & $09 / 10 / 91$ & Qualification of VersaTerm Pro & David Broxton \\
\hline 108 & $09 / 10 / 91$ & Qualification of KaleidaGraph & David Broxton \\
\hline 109 & $09 / 10 / 91$ & Structured Language Standards & Donn Hines \\
\hline 110 & $09 / 10 / 91$ & Shell-Script Standards & Donn Hines \\
\hline 111 & $09 / 10 / 91$ & DCL Standards & Donn Hines \\
\hline 114 & $09 / 09 / 91$ & $\begin{array}{c}\text { Qualification of Tri-Carb 2500TR Control } \\
\text { Software }\end{array}$ & Alan Mitchell \\
\hline 112 & $09 / 09 / 91$ & Qualification of COBRA Control System & Alan Mitchell \\
\hline
\end{tabular}


ECD STATUS ACCOUNTING FOR FOURTH QUARTER 1993

\begin{tabular}{|c|c|c|c|}
\hline ID & DATE & SUBJECT & DEVELOPER \\
\hline 113 & $09 / 09 / 91$ & $\begin{array}{c}\text { Qualification of DM } 3000 \mathrm{~F} \text { (Version 2.5) } \\
\text { Control Software }\end{array}$ & Alan Mitchell \\
\hline 116 & $10 / 10 / 91$ & Qualification of digiMatic & David Broxton \\
\hline 117 & $10 / 08 / 91$ & Certification of LSODPK & Eric Nuttall \\
\hline 121 & $10 / 29 / 91$ & Qualify dBase IV for the IBM PC & $\begin{array}{l}\text { Andrew } \\
\text { Burningham }\end{array}$ \\
\hline 123 & $10 / 29 / 91$ & Certification of NierGas Application & Jane Poths \\
\hline 124 & $10 / 30 / 91$ & Ada Condition Notification Facility & Gary Cort \\
\hline 125 & $11 / 01 / 91$ & Microsoft QuickBASIC Toolbox & $\begin{array}{c}\text { Gary } \\
\text { Luedemann }\end{array}$ \\
\hline 127 & $11 / 15 / 91$ & Interface Tables Design Changes & Donn Hines \\
\hline 126 & $11 / 15 / 91$ & SAS for Sun $X$ & $\begin{array}{c}\text { Brent } \\
\text { Newman }\end{array}$ \\
\hline 129 & $11 / 27 / 91$ & $\mathrm{~K} /$ Ar Measurement System & $\begin{array}{c}\text { Giday } \\
\text { WoldeGabriel }\end{array}$ \\
\hline 130 & $11 / 27 / 91$ & Update Standards Documents & $\begin{array}{c}\text { Steve } \\
\text { Donahue }\end{array}$ \\
\hline 131 & $12 / 17 / 91$ & Certification of Surface Display System & Bruce $\dot{C}$ rowe \\
\hline 132 & $12 / 17 / 91$ & Certification of AXUM & Bruce Crowe \\
\hline 133 & $12 / 17 / 91$ & Certification of SYSTAT & Bruce Crowe \\
\hline 134 & $02 / 27 / 92$ & Upgrade File List Standards & $\begin{array}{l}\text { Steve } \\
\text { Donahue }\end{array}$ \\
\hline 135 & $02 / 27 / 92$ & Certification of CENTX & $\begin{array}{c}\text { Brent } \\
\text { Newman }\end{array}$ \\
\hline 136 & $03 / 11 / 92$ & Interface Tables Application & Donn Hines \\
\hline 137 & $03 / 11 / 92$ & Certification of SXRAY/SUN & M. G.Snow \\
\hline 138 & $03 / 11 / 92$ & Certification of VISILOG & M. G. Snow \\
\hline 139 & $03 / 11 / 92$ & Certification of CIAP & M. G.Snow \\
\hline 140 & $(13 / 11 / 92$ & Certilication of Final' & M. G. Snow \\
\hline 141 & $03 / 11 / 92$ & Certification of GEO PLUS & M. G. Snow \\
\hline 142 & $(03 / 11 / 92$ & Certification of SUN/TORS & M. G.Snow \\
\hline 143 & $(13 / 11 / 92$ & Certification of MAC/TOPS & M. G.Snow \\
\hline
\end{tabular}


ECD STATUS ACCOUNTING FOR FOURTH QUARTER 1993

\begin{tabular}{|c|c|c|c|}
\hline ID & DATE & SUBJECT & DEVELOPER \\
\hline 144 & $03 / 11 / 92$ & Certification of IMIX & M. G.Snow \\
\hline 146 & $03 / 13 / 92$ & Certify COHORT Software Package & $\begin{array}{c}\text { Brent } \\
\text { Newman }\end{array}$ \\
\hline 147 & $03 / 12 / 92$ & Certify Additional Unix Operating Systems & $\begin{array}{c}\text { Steve } \\
\text { Donahue }\end{array}$ \\
\hline 148 & $03 / 12 / 92$ & Certify Additional FORTRAN Compilers & $\begin{array}{c}\text { Steve } \\
\text { Donahue }\end{array}$ \\
\hline 149 & $03 / 13 / 92$ & Ada Condition Notification Bug Fix & Gary Cort \\
\hline 150 & $03 / 13 / 92$ & Certify Tecplot & $\begin{array}{c}\text { Lynn } \\
\text { McDonald }\end{array}$ \\
\hline 151 & $03 / 13 / 92$ & Certify The Data Visualizer & $\begin{array}{l}\text { Lynn } \\
\text { McDonald }\end{array}$ \\
\hline 152 & $03 / 13 / 92$ & Certify AVS Software & $\begin{array}{l}\text { Lynn } \\
\text { McDonald }\end{array}$ \\
\hline 153 & $03 / 24 / 92$ & Certification of TABLECURVE & Steve Chipera \\
\hline 154 & $03 / 24 / 92$ & Certification of DIFFRACTINEL & Steve Chipera \\
\hline 155 & $03 / 25 / 92$ & Certify BIO-RAD Software & S. Chipera \\
\hline 156 & $03 / 25 / 92$ & Certify COREL DRAW & Steve Chipera \\
\hline 157 & $03 / 25 / 92$ & Certify Wildsoft Surveying System & Bruce Crowe \\
\hline 158 & $03 / 25 / 92$ & Certify SPECTRALAB.PC & Steve Chipera \\
\hline 159 & $03 / 25 / 92$ & Certify Postsoft & Steve Chipera \\
\hline 160 & $04 / 08 / 92$ & Certify PIZAZZ PLUS & Steve Chipera \\
\hline 161 & $04 / 08 / 92$ & Certify LCLSQ & Steve Chipera \\
\hline 162 & $04 / 08 / 92$ & Certify TGRAF & Steve Chipera \\
\hline 163 & $04 / 10 / 92$ & Certify Nanoscope III & $\begin{array}{l}\text { Marilyn } \\
\text { Hawley }\end{array}$ \\
\hline 164 & $04 / 15 / 92$ & Certify Chaos & Bruce Crowe \\
\hline 165 & $04 / 15 / 92$ & Certify Quattro Pro & Bruce Crowe \\
\hline 166 & $04 / 15 / 92$ & Certify Non-Linear Forecasting & Bruce Crowe \\
\hline 167 & $04 / 15 / 92$ & Certify MathCad & Bruce Crowe \\
\hline 168 & $04 / 15 / 92$ & Certify IGPET & Bruce Crowe \\
\hline
\end{tabular}


ECD STATUS ACCOUNTING FOR FOURTH QUARTER 1993

\begin{tabular}{|c|c|c|c|}
\hline ID & DATE & SUBJECT & DEVELOPER \\
\hline 169 & $04 / 15 / 92$ & Certify Designer & Bruce Crowe \\
\hline 170 & $07 / 30 / 92$ & Certify PKZip & $\begin{array}{c}\text { Brent } \\
\text { Newman }\end{array}$ \\
\hline 171 & $08 / 20 / 92$ & CDFTOOLS Application & Zora Dash \\
\hline 172 & $08 / 31 / 92$ & NLINISO.SAS & $\begin{array}{c}\text { Brent } \\
\text { Newman }\end{array}$ \\
\hline 173 & $10 / 13 / 92$ & Certify Surfer & Bruce Crowe \\
\hline 174 & $11 / 30 / 92$ & Certify XRFDRVOX & $\begin{array}{c}\text { Gary } \\
\text { Luedemann }\end{array}$ \\
\hline 175 & $01 / 21 / 93$ & Certify NONLIN_LSQ & $\begin{array}{c}\text { Bruce } \\
\text { Robinson }\end{array}$ \\
\hline 176 & $01 / 25 / 93$ & Certify STATISTICA & Pamela Rogers \\
\hline 177 & $02 / 01 / 93$ & Update of QUANT & Steve Chipera \\
\hline 180 & $03 / 11 / 93$ & Certify At Risk & Bruce Crowe \\
\hline 181 & $03 / 11 / 93$ & Certify Crystal Ball for Windows & Bruce Crowe \\
\hline 182 & $03 / 11 / 93$ & Certify Statistical Navigator & Bruce Crowe \\
\hline 178 & $03 / 11 / 93$ & Certify PATASC & Steve Chipera \\
\hline 179 & $03 / 11 / 93$ & Certify SiemGetPut & Steve Chipera \\
\hline 183 & $03 / 17 / 93$ & Certify Fox Pro & $\begin{array}{l}\text { Richard } \\
\text { Morley }\end{array}$ \\
\hline 184 & $06 / 22 / 93$ & Certify XRF-11 & Emily Kluk \\
\hline 185 & $07 / 06 / 93$ & Certify NEWMODF & Steve Chipera \\
\hline 186 & $08 / 27 / 93$ & Certify dBase IV & $\begin{array}{c}\text { Andrew } \\
\text { Burningham }\end{array}$ \\
\hline
\end{tabular}




\begin{tabular}{|c|c|c|c|}
\hline 10 & DATE & RELEASE LABEL & REF ECD \\
\hline \hline 1 & $04 / 15 / 91$ & FORTRAN_STD-01-00-00 & 10 \\
\hline 2 & $05 / 03 / 91$ & CCC_STD-01-00-00 & 45 \\
\hline 3 & $05 / 03 / 91$ & MAC_OS-01-00-00 & 37 \\
\hline 4 & $05 / 03 / 91$ & CCC_DATABASE-01-00-00 & 39 \\
\hline 5 & $05 / 03 / 91$ & 4D_DATABASE-01-00-00 & 40 \\
\hline 6 & $05 / 24 / 91$ & INGRES_4GL-01-00-00 & 8 \\
\hline 7 & $05 / 24 / 91$ & UNIX-01-00-00 & 11 \\
\hline 8 & $05 / 24 / 91$ & NETCDF-01-00-00 & 12 \\
\hline 9 & $05 / 24 / 91$ & DISSPLA-01-00-00 & 25 \\
\hline 10 & $06 / 05 / 91$ & FILELIST_STD-01-00-00 & 9 \\
\hline 11 & $06 / 14 / 91$ & VAX_VMS-01-00-00 & 6 \\
\hline 12 & $06 / 14 / 91$ & INGRES_RDBMS-01-00-00 & 7 \\
\hline 13 & $06 / 26 / 91$ & DOS-01-00-00 & 18 \\
\hline 14 & $06 / 26 / 91$ & DIFFRAC5000-01-00-00 & 1 \\
\hline 15 & $06 / 26 / 91$ & SHELXTL-01-00-00 & 2 \\
\hline 16 & $06 / 26 / 91$ & GSAS-01-00-00 & 31 \\
\hline 17 & $06 / 26 / 91$ & VACCELERATOR-01-00-00 & 30 \\
\hline 18 & $06 / 26 / 91$ & VAX_PDF2_CDIF-01-00-00 & 3 \\
\hline 19 & $06 / 28 / 91$ & FORTRAN_COMPILERS-01-00-00 & 86 \\
\hline 20 & $06 / 28 / 91$ & C_COMPILERS-01-00-00 & 87 \\
\hline 22 & $08 / 12 / 91$ & ADEM-01-00-00 & 65 \\
\hline 23 & $08 / 13 / 91$ & SpygglaSs-01-00-00 & 47 \\
\hline 24 & $08 / 13 / 91$ & PL-THERMAL-01-00-00 & 4 \\
\hline 25 & $08 / 22 / 91$ & GEO-CALC_PTA/PTX-01-00-00 & 29 \\
\hline 26 & $09 / 11 / 91$ & SQ-01-00-00 & 90 \\
\hline
\end{tabular}


ECN STATUS ACCOUNTING FOR FOURTH QUARTER 1993

\begin{tabular}{|c|c|c|c|}
\hline ID & DATE & RELEASE LABEL & REF ECD \\
\hline \hline 27 & $09 / 11 / 91$ & TASK8-01-00-00 & 88 \\
\hline 28 & $09 / 11 / 91$ & IDENT-01-00-00 & 89 \\
\hline 29 & $09 / 12 / 91$ & OS9-01-00-00 & 104 \\
\hline 30 & $09 / 12 / 91$ & FLEX-01-00-00 & 105 \\
\hline 31 & $09 / 13 / 91$ & VISTA-01-00-00 & 66 \\
\hline 32 & $09 / 17 / 91$ & ADA_STD-01-00-00 & 92 \\
\hline 33 & $09 / 16 / 91$ & NCSA_IMAGE-01-00-00 & 42 \\
\hline 34 & $10 / 03 / 91$ & TRI-CARB_2500TR-01-00-00 & 64 \\
\hline 35 & $10 / 18 / 91$ & LOTUS_123-01-00-00 & 58 \\
\hline 36 & $10 / 18 / 91$ & PLANPERFECT-01-00-00 & 91 \\
\hline 37 & $10 / 18 / 91$ & COBRA-01-00-00 & 54 \\
\hline 38 & $10 / 18 / 91$ & STRUCTURED_LANGUAGE_STD- & 109 \\
\hline 39 & $10 / 18 / 91$ & SHELL_SCRIPT_STD-01-00-00 & 110 \\
\hline 40 & $10 / 18 / 91$ & DCL_STD-01-00-00 & 111 \\
\hline 41 & $11 / 13 / 91$ & MINFILE-01-00-00 & 14 \\
\hline 42 & $11 / 13 / 91$ & MS_FORTRAN-01-00-00 & 51 \\
\hline 43 & $12 / 03 / 91$ & SIEMGETPUT-01-00-00 & 36 \\
\hline 44 & $12 / 09 / 91$ & DIONEX_AI450-01-00-00 & 17 \\
\hline 45 & $12 / 06 / 91$ & K_AR-01-00-00 & 129 \\
\hline 46 & $12 / 09 / 91$ & VERSATERM-01-00-00 & 107 \\
\hline 47 & $12 / 09 / 91$ & TMENU-01-00-00 & 56 \\
\hline 48 & $12 / 09 / 91$ & MS_DOS-01-00-000 & 59 \\
\hline 49 & $12 / 09 / 91$ & DIGIMATIC-01-00-00 & 116 \\
\hline 50 & $12 / 09 / 91$ & MS_C-01-00-00 & 49 \\
\hline 51 & $01 / 03 / 92$ & MS_WINDOWS-01-00-00 & 19 \\
\hline
\end{tabular}


ECN STATUS ACCOUNTING FOR FOURTH QUARTER 1993

\begin{tabular}{|c|c|c|c|}
\hline ID & DATE & RELEASE LABEL & REF ECD \\
\hline \hline 52 & $01 / 09 / 92$ & EXCEL_MAC-01-00-00 & 106 \\
\hline 53 & $01 / 09 / 92$ & KALEIDAGRAPH-01-00-00 & 108 \\
\hline 54 & $01 / 31 / 92$ & EM4105-01-00-00 & 16 \\
\hline 55 & $01 / 16 / 92$ & ADA_COMPILERS-01-00-00 & 102 \\
\hline 56 & $01 / 16 / 92$ & INTERFACE_TABLES-01-00-00 & 13 \\
\hline 57 & $01 / 27 / 92$ & MICROSOFT_BASIC-01-00-00 & 52 \\
\hline 58 & $01 / 27 / 92$ & SIGMAPLOT_01-00-00 & 53 \\
\hline 59 & $01 / 27 / 92$ & PCA_4000-01-00-00 & 50 \\
\hline 60 & $02 / 03 / 92$ & AXUM-01-00-00 & 132 \\
\hline 61 & $02 / 03 / 92$ & SYSTAT-01-00-00 & 133 \\
\hline 62 & $02 / 03 / 92$ & SURFACE_DISPLAY_SYSTEM-01- & 131 \\
\hline 63 & $02 / 19 / 92$ & 00-00 & 131 \\
\hline 64 & $02 / 19 / 92$ & ESCP-01-00-00 & 75 \\
\hline 65 & $02 / 20 / 92$ & RSS/1-01-00-00 & 41 \\
\hline 66 & $02 / 20 / 92$ & ADA_CONDITION-01-00-00 & 124 \\
\hline 67 & $02 / 26 / 92$ & GRAPHINT-01-00-00 & 35 \\
\hline 68 & $03 / 11 / 92$ & LSODPK-01-00-00 & 117 \\
\hline 69 & $03 / 13 / 92$ & GEO-PLUS-01-00-00 & 141 \\
\hline 70 & $03 / 13 / 92$ & SXRAY_SUN-01-00-00 & 137 \\
\hline 71 & $03 / 13 / 92$ & VISILOG-01-00-00 & 138 \\
\hline 72 & $03 / 13 / 92$ & CIAP-01-00-00 & 139 \\
\hline 73 & $03 / 13 / 92$ & FCIAP-01-00-00 & 140 \\
\hline 74 & $03 / 13 / 92$ & SŨN_TOFS-01-00-00 & 142 \\
\hline 75 & $03 / 13 / 92$ & MAC_TOPS-01-00-00 & 143 \\
\hline 76 & $03 / 13 / 92$ & IMIX-01-00-00 & 144 \\
\hline
\end{tabular}


ECN STATUS ACCOUNTING FOR FOURTH QUARTER 1993

\begin{tabular}{|c|c|c|c|}
\hline ID & DATE & RELEASE LABEL & REF ECD \\
\hline \hline 77 & $03 / 13 / 92$ & COHORT-01-00-00 & 146 \\
\hline 78 & $03 / 12 / 92$ & SAS_FOR_SUNX-01-00-00 & 126 \\
\hline 79 & $03 / 13 / 92$ & UNIX-01-00-01 & 147 \\
\hline 80 & $03 / 13 / 92$ & FORTRAN_COMPILERS-01-00-01 & 148 \\
\hline 81 & $03 / 13 / 92$ & TECPLOT-01-00-00 & 150 \\
\hline 82 & $03 / 13 / 92$ & DATA_VISUALIZER-01-00-00 & 151 \\
\hline 83 & $03 / 13 / 92$ & AVS-01-00-00 & 152 \\
\hline 84 & $03 / 27 / 92$ & TABLECURVE-01-00-00 & 153 \\
\hline 85 & $03 / 27 / 92$ & DIFFRACTINEL-01-00-00 & 154 \\
\hline 86 & $03 / 27 / 92$ & BIO-RAD-01-00-00 & 155 \\
\hline 87 & $03 / 27 / 92$ & COREL_DRAW-01-00-00 & 156 \\
\hline 88 & $03 / 27 / 92$ & WILDSOFT-01-00-00 & 157 \\
\hline 89 & $03 / 27 / 92$ & SPECTRALAB_PC-01-00-00 & 158 \\
\hline 90 & $03 / 27 / 92$ & POSTSOFT-01-00-00 & 159 \\
\hline 91 & $03 / 25 / 92$ & MS_QUICKBASIC-01-00-00 & 61 \\
\hline 92 & $03 / 27 / 92$ & BI-2030_AT-01-00-00 & 60 \\
\hline 93 & $03 / 30 / 92$ & PEAKFIT-01-00-00 & 100 \\
\hline 94 & $03 / 30 / 92$ & DM3000F-01-00-00 & 62 \\
\hline 95 & $03 / 30 / 92$ & WINDOWS_EXCEL-01-00-00 & 57 \\
\hline 96 & $03 / 30 / 92$ & HYPERCARD-01-00-00 & 38 \\
\hline 97 & $04 / 03 / 92$ & MATHEMATICA-01-00-00 & 55 \\
\hline 98 & $04 / 03 / 92$ & CLAMS-01-00-00 & 103 \\
\hline 99 & $04 / 10 / 92$ & PIZAZZ_PLUS-01-00-00 & 160 \\
\hline 100 & $04 / 10 / 92$ & LCLSQ-01-00-00 & 161 \\
\hline 101 & $04 / 10 / 92$ & TGRAF-01-00-00 & 162 \\
\hline 102 & $04 / 10 / 92$ & NANOSCOPE-01-00-00 & 163 \\
\hline
\end{tabular}


ECN STATUS ACCOUNTING FOR FOURTH QUARTER 1993

\begin{tabular}{|c|c|c|c|}
\hline ID & DATE & RELEASE LABEL & REFECD \\
\hline \hline 103 & $04 / 17 / 92$ & CHAOS-01-00-00 & 164 \\
\hline 104 & $04 / 17 / 92$ & QUATTRO_PRO-01-00-00 & 165 \\
\hline 105 & $04 / 17 / 92$ & NON_LINEAR-01-00-00 & 166 \\
\hline 106 & $04 / 17 / 92$ & MATHCAD-01-00-00 & 167 \\
\hline 107 & $04 / 17 / 92$ & IGPET-01-00-00 & 168 \\
\hline 108 & $04 / 17 / 92$ & DESIGNER-01-00-00 & 169 \\
\hline 109 & $04 / 28 / 92$ & ADA_CONDITION-01-00-01 & 149 \\
\hline 110 & $05 / 05 / 92$ & CDFTOOLS-01-00-00 & 24 \\
\hline 111 & $07 / 30 / 92$ & PKZIP-01-00-00 & 170 \\
\hline 112 & $08 / 28 / 92$ & INTERFACE_TABLES-01-00-01 & 136 \\
\hline 113 & $10 / 13 / 92$ & SURFER-01-00-00 & 173 \\
\hline 114 & $10 / 08 / 92$ & QUANT-01-00-00 & 33 \\
\hline 116 & $11 / 24 / 92$ & GENPLOT-01-00-00 & 23 \\
\hline 115 & $11 / 25 / 92$ & CDFTOOLS-01-00-01 & 171 \\
\hline 117 & $01 / 29 / 93$ & STATISTICA-01-00-00 & 176 \\
\hline 118 & $02 / 12 / 93$ & SORBEQ-01-00-00\# & 20 \\
\hline 119 & $03 / 11 / 93$ & AT_RISK-01-00-00 & 180 \\
\hline 120 & $03 / 11 / 93$ & CRYSTAL_BALL_WINDOWS-01- & 181 \\
\hline 121 & $03 / 11 / 93$ & STATISTICAL_NAVIGATOR-01-00- & 182 \\
\hline 122 & $03 / 17 / 93$ & FOX_PRO-01-00-00 & 183 \\
\hline 123 & $03 / 23 / 93$ & QUICKBASIC_STDS-01-00-00 & 77 \\
\hline 124 & $03 / 24 / 93$ & TRA_CRN-01-00-00 Pioilationa11 & 5 \\
\hline 125 & $055 / 05 / 93$ & PRelease & 184 \\
\hline 126 & $06 / 22 / 93$ & XRF-11-01-0(-00) & \\
\hline
\end{tabular}


ECN STATUS ACCOUNTING FOR FOURTH QUARTER 1993

\begin{tabular}{|c|c|c|c|}
\hline ID & DATE & RELEASE LABEL & REFECD \\
\hline \hline 127 & $07 / 06 / 93$ & NEWMODF-01-00-00 & 185 \\
\hline 128 & $8 / 27 / 93$ & dBASE_IV-01-00-00 & 186 \\
\hline
\end{tabular}




\begin{tabular}{|c|c|c|c|}
\hline ID & APPLICATION & REQUESTOR & DATE \\
\hline 1 & FORTRAN_STD-01-00-00 & David Morris & $04 / 23 / 91$ \\
\hline 2 & CCC_STD-01-00-00 & Gary Cort & $06 / 25 / 91$ \\
\hline 3 & MAC_OS-01-00-00 & Gary Cort & $06 / 25 / 91$ \\
\hline 4 & CCC_DATABASE- $01-00-00$ & Gary Cort & $06 / 25 / 91$ \\
\hline 5 & 4D_DATABASE- $01-\infty 0-00$ & Gary Cort & $06 / 25 / 91$ \\
\hline 6 & INGRES_4GL-01-00-00 & Gary Cort & $06 / 25 / 91$ \\
\hline 7 & UNIX-01-00-00 & Gary Cort & $06 / 25 / 91$ \\
\hline 8 & NETCDF- $01-00-00$ & Gary Cort & $06 / 25 / 91$ \\
\hline 9 & VAX_VMS-01-00-00 & Gary Cort & $06 / 25 / 91$ \\
\hline 10 & INGRES_RDBMS-01-00-00 & Gary Cort & $06 / 25 / 91$ \\
\hline 11 & FORTRAN_STD-01-00-00 & Bruce Crowe & $07 / 01 / 91$ \\
\hline 15 & FORTRAN_STD- $01-00-00$ & Robert Loux & $07 / 01 / 91$ \\
\hline 18 & FORTRAN_STD-01-00-00 & Joey Gorman & $07 / 01 / 91$ \\
\hline 19 & FORTRAN_STD-01-00-00 & Richard Morley & $07 / 01 / 91$ \\
\hline 20 & FORTRAN_STD-01-00-00 & Dr. Heino Nitsche & $07 / 01 / 91$ \\
\hline 21 & FORTRAN_STD-01-00-00 & Ross Oblad & $07 / 01 / 91$ \\
\hline 24 & FORTRAN_STD-01-00-00 & David Bish & $07 / 01 / 91$ \\
\hline 27 & FORTRAN_STD-01-00-00 & Katherine Campbell & $07 / 01 / 91$ \\
\hline 30 & FORTRAN_STD-01-00-00 & Gary Cort & $07 / 01 / 91$ \\
\hline 32 & FILELIST_STD-01-00-00 & Bruce Crowe & $07 / 01 / 91$ \\
\hline 36 & FILELIST_STD-01-00-00 & Robert Loux & $07 / 01 / 91$ \\
\hline 39 & FILELIST_STD-01-00-00 & Joey Gorman & $07 / 01 / 91$ \\
\hline 40 & FILELIST_STD-01-001-00 & Richard Morley & $07 / 01 / 91$ \\
\hline 41 & FILELIST_STD-01-00-(1) & Dr. Heino Nitsche & $07 / 01 / 91$ \\
\hline
\end{tabular}


SDDR STATUS ACCOUNTING FOR FOURTH QUARTER 1993

\begin{tabular}{|c|c|c|c|}
\hline ID & APPLICATION & REQUESTOR & DATE \\
\hline 42 & FILELIST_STD-01-00-00 & Ross Oblad & $07 / 01 / 91$ \\
\hline 45 & FILELIST_STD-01-00-00 & David Bish & $07 / 01 / 91$ \\
\hline 48 & FILELIST_STD-01-00-00 & Katherine Campbell & $07 / 01 / 91$ \\
\hline 51 & FILELIST_STD-01-00-00 & Gary Cort & $07 / 01 / 91$ \\
\hline 55 & FORTRAN_STD-01-00-00 & Inez Triay & $08 / 01 / 91$ \\
\hline 57 & FORTRAN_STD-01-00-00 & Bruce Robinson & $08 / 01 / 91$ \\
\hline 61 & FORTRAN_STD-01-00-00 & Arend Meijer & $08 / 01 / 91$ \\
\hline 64 & FORTRAN_STD-01-00-00 & Carol LaDelfe & $08 / 01 / 91$ \\
\hline 66 & FORTRAN_STD-01-00-00 & Donn Hines & $08 / 01 / 91$ \\
\hline 71 & FILELIST_STD-01-00-00 & Inez Triay & $08 / 01 / 91$ \\
\hline 73 & FILELIST_STD-01-00-00 & Bruce Robinson & $08 / 01 / 91$ \\
\hline 77 & FILELIST_STD-01-00-00 & Arend Meijer & $08 / 01 / 91$ \\
\hline 80 & FILELIST_STD-01-00-00 & Carol LaDelfe & $08 / 01 / 91$ \\
\hline 82 & FILELIST_STD-01-00-00 & Donn Hines & $08 / 01 / 91$ \\
\hline 86 & FILELIST_STD-01-00-00 & Steve Donahue & $08 / 01 / 91$ \\
\hline 87 & FORTRAN_STD-01-00-00 & Steve Donahue & $08 / 01 / 91$ \\
\hline 88 & C_COMPILERS-01-00-00 & David Broxton & $08 / 01 / 91$ \\
\hline 89 & FORTRAN_COMPILERS-01-00-00 & David Broxton & $08 / 01 / 91$ \\
\hline 90 & DOS-01-00-00 & David Broxton & $08 / 01 / 91$ \\
\hline 91 & VAX_VMX-01-00-00 & David Broxton & $08 / 01 / 91$ \\
\hline 92 & DISSPLA-01-00-00 , & David Broxton & $08 / 01 / 91$ \\
\hline 93 & MAC_OS-01-00-00 & David Broxton & $08 / 01 / 91$ \\
\hline$\because 4$ & VAX_PDF2_CUIF-(II-())-(u) & David Bish & $08 / 13 / 9 i$ \\
\hline 95 & VAX_PDF2_CDIF-01-00-00 & Steve Chipera & $08 / 13 / 91$ \\
\hline 96 & VACCELERATOR-01-00-00 & David Bish & $08 / 13 / 91$ \\
\hline 97 & VACCELERATOR-(01-(0)-00 & Steve Chipera & $08 / 13 / 91$ \\
\hline
\end{tabular}


SDDR STATUS ACCOUNTING FOR FOURTH QUARTER 1993

\begin{tabular}{|c|c|c|c|}
\hline ID & APPLICATION & REQUESTOR & DATE \\
\hline 98 & GSAS-01-00-00 & David Bish & $08 / 13 / 91$ \\
\hline 99 & GSAS-01-00-00 & Steve Chipera & $08 / 13 / 91$ \\
\hline 100 & SHELXTL-01-00-00 & David Bish & $08 / 13 / 91$ \\
\hline 101 & SHELXTL-01-00-00 & Steve Chipera & $08 / 13 / 91$ \\
\hline 102 & DIFFRAC $5000-01-00-00$ & David Bish & $08 / 13 / 91$ \\
\hline 103 & DIFFRAC $5000-01-00-00$ & Steve Chipera & $08 / 13 / 91$ \\
\hline 104 & CCC_STD-01-00-00 & Gary Cort & $09 / 11 / 91$ \\
\hline 105 & FLEX-01-00-00 & M. G.Snow & $09 / 12 / 91$ \\
\hline 106 & IDENT-01-00-00 & M. G.Snow & $09 / 12 / 91$ \\
\hline 107 & OS9-01-00-00 & M. G.Snow & $09 / 12 / 91$ \\
\hline 108 & SQ-01-00-00 & M. G. Snow & $09 / 12 / 91$ \\
\hline 109 & TASK8-01-00-00 & M. G. Snow & $09 / 12 / 91$ \\
\hline 110 & VISTA-01-00-00 & M. G. Snow & $09 / 13 / 91$ \\
\hline 111 & FLEX-01-00-00 & David Broxton & $09 / 13 / 91$ \\
\hline 112 & IDENT-01-00-10 & David Broxton & $09 / 13 / 91$ \\
\hline 113 & OS9-01-00-00 & David Broxton & $09 / 13 / 91$ \\
\hline 114 & SQ-01-00-00 & David Broxton & $09 / 13 / 91$ \\
\hline 115 & TASK8-01-00-00 & David Broxton & $09 / 13 / 91$ \\
\hline 116 & VISTA-01-00-00 & David Broxton & $09 / 13 / 91$ \\
\hline 117 & CCC_STD-01-00-00 & Steve Donahue & $09 / 17 / 91$ \\
\hline 118 & ADEM-01-00-00 & Pegr Snow & $08 / 29 / 91$ \\
\hline 119 & GEO-CALC_PTA/PTX-01-00-00 & Steve Chipera & $09 / 17 / 91$ \\
\hline 120 & GEO-CALC_I'TA/i'TX-01-00-00 & Eavic: Eish & 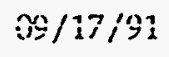 \\
\hline 121 & PL-THERMAL-01-00-(0) & David Bish & $(19 / 17 / 91$ \\
\hline 122 & PL-THERMAL-01-00-00 & Steve Chipera & $09 / 17 / 91$ \\
\hline 123 & VISTA-(1)-(1)(1)-(1) & Barbara Carlos & $10 / 10 / 91$ \\
\hline
\end{tabular}


SDDR STATUS ACCOUNTING FOR FOURTH QUARTER 1993

\begin{tabular}{|c|c|c|c|}
\hline ID & APPLICATION & REQUESTOR & DATE \\
\hline 124 & TASK8-01-00-00 & Barbara Carlos & $10 / 10 / 91$ \\
\hline 125 & SQ-01-00-00 & Barbara Carlos & $10 / 10 / 91$ \\
\hline 126 & IDENT-01-00-00 & Barbara Carlos & $10 / 10 / 91$ \\
\hline 127 & ADEM-01-00-00 & Barbara Carlos & $10 / 10 / 91$ \\
\hline 128 & OS9-01-00-00 & Barbara Carlos & $10 / 10 / 91$ \\
\hline 129 & FLEX-01-00-00 & Barbara Carlos & $10 / 10 / 91$ \\
\hline 130 & DIFFRAC5000-01-00-00 & Giday Woldegabriel & $10 / 11 / 91$ \\
\hline 131 & VAX_PDF2_CDIF-01-00-00 & Giday Woldegabriel & $10 / 11 / 91$ \\
\hline 132 & VISTA-01-00-00 & Giday Woldegabriel & $10 / 11 / 91$ \\
\hline 133 & ADEM-01-00-00 & Giday Woldegabriel & $10 / 11 / 91$ \\
\hline 134 & SQ-01-00-00 & Giday Woldegabriel & $10 / 11 / 91$ \\
\hline 135 & TASK8-01-00-00 & Giday Woldegabriel & $10 / 11 / 91$ \\
\hline 136 & IDENT-01-00-00 & Giday Woldegabriel & $10 / 11 / 91$ \\
\hline 137 & OS9-01-00-00 & Giday Woldegabriel & $10 / 11 / 91$ \\
\hline 138 & FLEX-01-00-00 & Giday Woldegabriel & $10 / 11 / 91$ \\
\hline 139 & VISTA-01-00-00 & Sandra Craven & $10 / 11 / 91$ \\
\hline 140 & TASK8-01-00-00 & Sandra Craven & $10 / 11 / 91$ \\
\hline 141 & SQ-01-00-00 & Sandra Craven & $10 / 11 / 91$ \\
\hline 142 & IDENT-01-00-00 & Sandra Craven & $10 / 11 / 91$ \\
\hline 143 & ADEM-01-00-00 & Sandra Craven & $10 / 11 / 91$ \\
\hline 144 & OS9-01-00-00 & Sandra Craven & $10 / 11 / 91$ \\
\hline 145 & FLEX-01-00-00 & Sandra Craven & $10 / 11 / 91$ \\
\hline i 46 & 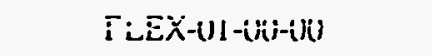 & David T. Vaniman & $16 j i 17 / 91$ \\
\hline 147 & OS9-01-00-00 & David T. Vaniman & $10 / 17 / 91$ \\
\hline 148 & [DENT-(1)-(00-(0) & David T. Vaniman & $10 / 17 / 91$ \\
\hline 149 & ADEM-01-00-00) & David T. Vaniman & $10 / 17 / 91$ \\
\hline
\end{tabular}


SDDR STATUS ACCOUNTING FOR FOURTH QUARTER 1993

\begin{tabular}{|c|c|c|c|}
\hline ID & APPLICATION & REQUESTOR & DATE \\
\hline 150 & SQ-01-00-00 & David T. Vaniman & $10 / 17 / 91$ \\
\hline 151 & TASK8-01-00-00 & David T. Vaniman & $10 / 17 / 91$ \\
\hline 152 & VISTA-01-00-00 & David T. Vaniman & $10 / 17 / 91$ \\
\hline 153 & ADA_STD-01-00-00 & Gary Cort & $10 / 17 / 91$ \\
\hline 154 & ADA_STD-01-00-00 & Will Dearholt & $10 / 23 / 91$ \\
\hline 155 & MS_FORTRAN-01-00-00 & Scott A. Carpenter & $08 / 28 / 91$ \\
\hline 156 & DOS-01-00-00 & Brent Newman & $11 / 20 / 91$ \\
\hline 157 & DOS-01-00-00 & Mike Ebinger & $11 / 20 / 91$ \\
\hline 158 & DIONEX_AI450-01-00-00 & Mike Ebinger & $11 / 20 / 91$ \\
\hline 159 & MS_WINDOWS-01-00-00 & Mike Ebinger & $11 / 20 / 91$ \\
\hline 161 & MS_WINDOWS-01-00-00 & Brent Newman & $11 / 20 / 91$ \\
\hline 162 & MS_C-01-00-00 & Scott A. Carpenter & $11 / 20 / 91$ \\
\hline 163 & LOTUS_1-2-3-01-00-00 & Pamela Rogers & $11 / 20 / 91$ \\
\hline 164 & PCA_4000-01-00-00 & Scott A. Carpenter & $11 / 20 / 91$ \\
\hline 165 & MICROSOFT_BASIC-01-00-00 & Scott A. Carpenter & $11 / 20 / 91$ \\
\hline 166 & SIGMAPLOT_01-00-00 & Scott A. Carpenter & $11 / 20 / 91$ \\
\hline 167 & $\mathrm{RS} / 1-01-00-00$ & Giday Woldegabriel & $11 / 20 / 91$ \\
\hline 168 & $\mathrm{RS} / 1-01-00-00$ & Gary Luedemann & $11 / 20 / 91$ \\
\hline 169 & DATAFLEX_360-01-00-00 & Gary Luedemann & $11 / 20 / 91$ \\
\hline 170 & ESCP- $-01-00-00$ & Gary Luedemann & $11 / 20 / 91$ \\
\hline 171 & FILELIST_STD-01-00-00 & Marian Schimicci & $11 / 22 / 91$ \\
\hline 172 & ADA_STD-01-00-00 & Zora Dash & $12 / 03 / 91$ \\
\hline 173 & DISSPLA-1)1-(0)-(i) & Bruce Robinson & $12 / 03 / 91$ \\
\hline 174 & UNIX-01-00-00 & Bruce Robinson & $12 / 03 / 91$ \\
\hline 175 & NETCDF- $01-(0)-00$ & Bruce Robinson & $12 / 03 / 91$ \\
\hline 176 & FORTRAN_COMPILERS-(1)1-(K)-00) & Bruce Robinson & $12 /(13 / 91$ \\
\hline
\end{tabular}


SDDR STATUS ACCOUNTING FOR FOURTH QUARTER 1993

\begin{tabular}{|c|c|c|c|}
\hline ID & APPLICATION & REQUESTOR & DATE \\
\hline 177 & Ada_STD-01-00-00 & Donn Hines & $12 / 03 / 91$ \\
\hline 178 & DCL_STD-01-00-00 & Donn Hines & $12 / 04 / 91$ \\
\hline 179 & SHELL_SCRIPT_STD-01-00-00 & Donn Hines & $12 / 04 / 91$ \\
\hline 180 & STRUCTURED_LANGUAGE_STD-01-00-00 & Donn Hines & $12 / 04 / 91$ \\
\hline 181 & CCC_STD-01-00-00 & Donn Hines & $12 / 04 / 91$ \\
\hline 182 & DIONEX_AI450-01-00-00 & Brent Newman & $12 / 16 / 91$ \\
\hline 183 & FORTRAN_STD-01-00-00 & Steve Chipera & $12 / 10 / 91$ \\
\hline 184 & DCL_STD-01-00-00 & Steve Chipera & $12 / 10 / 91$ \\
\hline 185 & FILELIST_STD-01-00-00 & Steve Chipera & $12 / 10 / 91$ \\
\hline 186 & MS_DOS-01-00-00 & Scott A. Carpenter & $01 / 03 / 92$ \\
\hline 187 & KALEIDAGRAPH-01-00-00 & David Broxton & $01 / 10 / 92$ \\
\hline 188 & VERSATERM-01-00-00 & David Broxton & $01 / 10 / 92$ \\
\hline 189 & EXCEL_MAC-01-00-00 & David Broxton & $01 / 10 / 92$ \\
\hline 190 & DIGIMATIC-01-00-00 & David Broxton & $01 / 10 / 92$ \\
\hline 191 & INTERFACE_TABLES-01-00-00 & Bruce Robinson & $01 / 31 / 92$ \\
\hline 192 & ADA_CONDITION $-01-00-00$ & Gary Cort & $02 / 26 / 92$ \\
\hline 193 & MS_FORTRAN-01-00-00 & Brent Newman & $02 / 25 / 92$ \\
\hline 194 & DCL_STD-01-00-00 & Steve Donahue & $03 / 05 / 92$ \\
\hline 195 & FORTRAN_STD-01-00-00 & Kenneth Eggert & $03 / 09 / 92$ \\
\hline 196 & MAC_OS-01-00-00 & Kenneth Eggert & $03 / 09 / 92$ \\
\hline 197 & UNIX-01-00-00 & Kenneth Eggert & $03 / 09 / 92$ \\
\hline 198 & FILELIST_STD-01-00-00 & Kenneth Eggert & $03 / 09 / 92$ \\
\hline Iyy & FORTRAN_COMPILERS-(01-0(1)-(0) & Kenneth Eggert & $03 / 09 / 92$ \\
\hline 200 & Spyglass-01-00-00 & Kenneth Eggert & $03 / 09 / 92$ \\
\hline 201 & NCSA_IMAGE-01-00-00 & Kenneth Eggert & $03 / 09 / 92$ \\
\hline 202 & VERSATERM-01-00-(0) & Kenneth Eggert & $03 / 09 / 92$ \\
\hline
\end{tabular}


SDDR STATUS ACCOUNTING FOR FOURTH QUARTER 1993

\begin{tabular}{|c|c|c|c|}
\hline ID & APPLICATION & REQUESTOR & DATE \\
\hline 203 & EXCEL_MAC-01-00-00 & Kenneth Eggert & $03 / 09 / 92$ \\
\hline 204 & KALEIDAGRAPH-01-00-00 & Kenneth Eggert & $03 / 09 / 92$ \\
\hline 205 & VAX_VMS-01-00-00 & Steve Chipera & $03 / 13 / 92$ \\
\hline 206 & DOS-01-00-00 & Steve Chipera & $03 / 13 / 92$ \\
\hline 207 & MS_DOS-01-00-00 & Steve Chipera & $03 / 13 / 92$ \\
\hline 208 & MS_WINDOWS-01-00-100 & Steve Chipera & $03 / 13 / 92$ \\
\hline 209 & MAC_OS-01-00-00 & Steve Chipera & $03 / 13 / 92$ \\
\hline 210 & MINFILE-01-00-00 & Steve Chipera & $03 / 13 / 92$ \\
\hline 211 & EM4105-01-00-00 & Steve Chipera & $03 / 13 / 92$ \\
\hline 212 & DISSPLA-01-00-00 & Steve Chipera & $03 / 13 / 92$ \\
\hline 213 & VERSATERM-01-00-(00 & Steve Chipera & $03 / 13 / 92$ \\
\hline 214 & GRAPHINT-01-00-00 & Steve Chipera & $03 / 13 / 92$ \\
\hline 215 & SIEMGETPUT-01-00-00 & Steve Chipera & $03 / 13 / 92$ \\
\hline 216 & FORTRAN_COMPILERS-01- $\infty 0-00$ & Steve Chipera & $03 / 13 / 92$ \\
\hline 217 & INTERFACE_TABLES-01-00-100 & Steve Chipera & $03 / 13 / 92$ \\
\hline 218 & NETCDF-01-(0)-00 & Steve Chipera & $03 / 13 / 92$ \\
\hline 219 & $\mathrm{RS} / 1-01-00-00$ & Steve Chipera & $03 / 13 / 92$ \\
\hline 220 & VAX_VMS-01-00-00 & David Bish & $03 / 13 / 92$ \\
\hline 221 & DOS-01-00-00 & David Bish & $03 / 13 / 92$ \\
\hline 222 & MS_DOS-01-00-00 & David Bish & $03 / 13 / 92$ \\
\hline 223 & MS_WINDOWS-01-00-00 & David Bish & $03 / 13 / 92$ \\
\hline 224 & MAC_OS-01-(00-00) & David Bish & $03 / 13 / 92$ \\
\hline 225 & 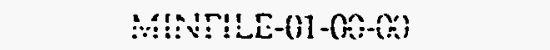 & Poytis Bish & $93,13,92$ \\
\hline 226 & EM4105-01-(00-(X) & David Bish & $03 / 13 / 92$ \\
\hline 227 & DISSPLA-01-00-00 & David Bish & $03 / 13 / 92$ \\
\hline 228 & VERSATERM-(01-00-(0) & David Bish & $03 / 13 / 92$ \\
\hline
\end{tabular}




\section{SDDR STATUS ACCOUNTING FOR FOURTH QUARTER 1993}

\begin{tabular}{|c|c|c|c|}
\hline ID & APPLICATION & REQUESTOR & DATE \\
\hline 229 & GRAPHINT-01-00-00 & David Bish & $03 / 13 / 92$ \\
\hline 230 & SIEMGETPUT-01-00-00 & David Bish & $03 / 13 / 92$ \\
\hline 231 & FORTRAN_COMPILERS-01-00-00 & David Bish & $03 / 13 / 92$ \\
\hline 232 & INTERFACE_TABLES-01-00-00 & David Bish & $03 / 13 / 92$ \\
\hline 233 & NETCDF-01-00-00 & David Bish & $03 / 13 / 92$ \\
\hline 234 & $\mathrm{RS} / 1-01-00-00$ & David Bish & $03 / 13 / 92$ \\
\hline 235 & TECPLOT-01-00-00 & Kenneth Eggert & $03 / 13 / 92$ \\
\hline 236 & DATA_VISUALIZER-01-00-00 & Kenneth Eggert & $03 / 13 / 92$ \\
\hline 237 & AVS-01-00-00 & Kenneth Eggert & $03 / 13 / 92$ \\
\hline 238 & Excel-Windows $-01-00-00$ & Mike Murrell & $03 / 16 / 92$ \\
\hline 239 & SIGMAPLOT-01-00-00 & Mike Murrell & $03 / 16 / 92$ \\
\hline 240 & MS_WINDOWS-01-00-00 & Mike Murrell & $03 / 16 / 92$ \\
\hline 241 & MS_DOS-01-00-00 & Mike Murrell & $03 / 16 / 92$ \\
\hline 242 & COHORT-01-00-00 & Brent Newman & $03 / 13 / 92$ \\
\hline 243 & MS_WINDOWS-01-00-00 & Martin A. Ott & $03 / 16 / 92$ \\
\hline 244 & WINDOWS_EXCEL-01-00-00 & Martin A. Ott & $03 / 16 / 92$ \\
\hline 245 & MS_DOS-01-00-00 & Martin A. Ott & $03 / 16 / 92$ \\
\hline 246 & TRI-CARB_2500TR-01-00-00 & Martin A. Ott & $03 / 16 / 92$ \\
\hline 247 & MS_WINDOWS- $01-00-00$ & Alan J. Mitchell & $03 / 16 / 92$ \\
\hline 248 & COBRA-01-00-00 & Alan J. Mitchell & $03 / 16 / 92$ \\
\hline 249 & TMENU-01-00-00 & Alan J. Mitchell & $03 / 16 / 92$ \\
\hline 250 & WINDOWS_EXCEL-01-00-00 & Alan J. Mitchell & $03 / 16 / 92$ \\
\hline $25 i$ & LUTUS_i23-iii-iöj-60i & Alan j. Mítcirieii & $6 ; 16 ; 92$ \\
\hline 252 & MS_DOS-01-00-(10) & Alan J. Mitchell & $03 / 16 / 92$ \\
\hline 253 & TRI-CARB_2500TR-(01-00-00 & Alan J. Mitchell & $03 / 16 / 92$ \\
\hline 254 & BI_2030_AT-(01-00-00 & Alan J. Mitchell & $03 / 16 / 92$ \\
\hline
\end{tabular}


SDDR STATUS ACCOUNTING FOR FOURTH QUARTER 1993

\begin{tabular}{|c|c|c|c|}
\hline ID & APPLICATION & REQUESTOR & DATE \\
\hline 255 & DM3000F-01-00-00 & Alan J. Mitchell & $03 / 16 / 92$ \\
\hline 256 & MS_WINDOWS-01-00-00 & Ines $R$. Triay & $03 / 16 / 92$ \\
\hline 257 & MAC_OS-01-00-00 & Ines R. Triay & $03 / 16 / 92$ \\
\hline 258 & COBRA-01-00-00 & Ines R. Triay & $03 / 16 / 92$ \\
\hline 259 & TMENU-01-00-00 & Ines R. Triay & $03 / 16 / 92$ \\
\hline 260 & LOTUS_123-01-00-00 & Ines $\mathrm{R}$. Triay & $03 / 16 / 92$ \\
\hline 261 & MS_DOS-01-00-00 & Ines R. Triay & $03 / 16 / 92$ \\
\hline 262 & HYPERCARD-01-00-00 & Ines R. Triay & $03 / 16 / 92$ \\
\hline 263 & MATHEMATICA-01-00-00 & Ines R. Triay & $03 / 16 / 92$ \\
\hline 264 & WINDOWS_EXCEL-01-00-00 & Ines R. Triay & $03 / 16 / 92$ \\
\hline 265 & BI-2030_AT-01-00-00 & Ines $\mathrm{R}$. Triay & $03 / 16 / 92$ \\
\hline 266 & QUICK_BASIC-01-00-00 & Ines R. Triay & $03 / 16 / 92$ \\
\hline 267 & DM3000F-01-00-00 & Ines R. Triay & $03 / 16 / 92$ \\
\hline 268 & TRI-CARB_2500TR-01-00-00 & Ines R. Triay & $03 / 16 / 92$ \\
\hline 269 & PEAKFIT-01-00-00 & Ines R. Triay & $03 / 16 / 92$ \\
\hline 270 & CLAMS-01-00-00 & Ines R. Triay & $03 / 16 / 92$ \\
\hline 271 & EXCEL_MAC-01-00-00 & Ines $\mathrm{R}$. Triay & $03 / 16 / 92$ \\
\hline 272 & VERSATERM-01-00-00 & Ines R. Triay & $03 / 16 / 92$ \\
\hline 273 & MS_WINDOWS-01-00-00 & Connie M. Overly & $04 / 18 / 92$ \\
\hline 274 & MAC_OS-01-00-00 & Connie M. Overly & $04 / 18 / 92$ \\
\hline 275 & COBRA-01-00-00 & Connie M. Overly & $04 / 18 / 92$ \\
\hline 276 & TMENU-01-00-00 & Connie M. Overly & $04 / 18 / 92$ \\
\hline $2 \%$ & LOTUS_123-01-()(1-(0) & Connie iví. Overiy & $0+18 / 92$ \\
\hline 278 & MS_DOS-01-00-00 & Connie M. Overly & $04 / 18 / 92$ \\
\hline 279 & HYPERCARD-01-(00-00) & Connie M. Overly & $(24 / 18 / 92$ \\
\hline 280 & MATHEMATICA-01-(10-00) & Connie M. Overly & $(44 / 18 / 92$ \\
\hline
\end{tabular}


SDDR STATUS ACCOUNTING FOR FOURTH QUARTER 1993

\begin{tabular}{|c|c|c|c|}
\hline ID & APPLICATION & REQUESTOR & DATE \\
\hline 281 & WINDOWS_EXCEL-01-00-00 & Connie M. Overly & $04 / 18 / 92$ \\
\hline 282 & BI_2030AT-01-00-00 & Connie M. Overly & $04 / 18 / 92$ \\
\hline 283 & QUICK_BASIC-01-00-00 & Connie M. Overly & $04 / 18 / 92$ \\
\hline 284 & DM3000F-01-00-00 & Connie M. Overly & $04 / 18 / 92$ \\
\hline 285 & TRI-CARB_2500TR-01-00-00 & Connie M. Overly & $04 / 18 / 92$ \\
\hline 286 & PEAKFIT-01-00-00 & Connie M. Overly & $04 / 18 / 92$ \\
\hline 287 & CLAMS-01-00-00 & Connie M. Overly & $04 / 18 / 92$ \\
\hline 288 & EXCEL_MAC-01-00-00 & Connie M. Overly & $04 / 18 / 92$ \\
\hline 289 & VERSATERM-01-00-00 & Connie M. Overly & $04 / 18 / 92$ \\
\hline 290 & SAS_FOR_SUNX-01-00-00 & Brent Newman & $03 / 19 / 92$ \\
\hline 291 & FORTRAN_COMPILERS-01-00-00 & Gary Cort & $03 / 24 / 92$ \\
\hline 292 & ADEM-01-00-00 & Robert Raymond & $03 / 27 / 92$ \\
\hline 293 & $S Q-01-00-00$ & Robert Raymond & $03 / 27 / 92$ \\
\hline 294 & TASK8-01-00-00 & Robert Raymond & $03 / 27 / 92$ \\
\hline 295 & IDENT-01-00-00 & Robert Raymond & $03 / 27 / 92$ \\
\hline 296 & OS9-01-00-00 & Robert Raymond & $03 / 27 / 92$ \\
\hline 297 & FLEX-01-00-00 & Robert Raymond & $03 / 27 / 92$ \\
\hline 298 & VISTA-01-00-00 & Robert Raymond & $03 / 27 / 92$ \\
\hline 299 & VERSATERM-01-00-00 & Robert Raymond & $03 / 27 / 92$ \\
\hline 300 & EXCEL_MAC-01-00-00 & Robert Raymond & $03 / 27 / 92$ \\
\hline 301 & KALEIDAGRAPH-01-00-00 & Robert Raymond & $03 / 27 / 92$ \\
\hline 302 & RS/1-01-00-00 & Robert Raymond & $03 / 27 / 92$ \\
\hline 303 & GEU-i'LUS-(i1-ik)-(i) & Robert Raymond & $03 / 27 / 92$ \\
\hline 304 & SXRAY-01-(00-1)0 & Robert Raymond & $03 / 27 / 92$ \\
\hline 305 & VISILOG- $-01-00-00$ & Robert Raymond & $03 / 27 / 92$ \\
\hline 306 & CIAP-(01-(00-(0) & Robert Raymond & $03 / 27 / 92$ \\
\hline
\end{tabular}


SDDR STATUS ACCOUNTING FOR FOURTH QUARTER 1993

\begin{tabular}{|c|c|c|c|}
\hline ID & APPLICATION & REQUESTOR & DATE \\
\hline 307 & FCIAP-01-00-00 & Robert Raymond & $03 / 27 / 92$ \\
\hline 308 & SUN_TOPS-01-00-00 & Robert Raymond & $03 / 27 / 92$ \\
\hline 309 & MAC_TOPS-01-00-00 & Robert Raymond & $03 / 27 / 92$ \\
\hline 310 & IMIX-01-00-00 & Robert Raymond & $03 / 27 / 92$ \\
\hline 311 & UNIX-01-00-00 & Robert Raymond & $03 / 27 / 92$ \\
\hline 312 & DATAFLEX_360-01-00-00 & Robert Raymond & $03 / 27 / 92$ \\
\hline 313 & ESCP-01-00-00 & Robert Raymond & $03 / 27 / 92$ \\
\hline 314 & ADEM-01-00-00 & Gary Luedemann & $03 / 27 / 92$ \\
\hline 315 & SQ-01-00-00 & Gary Luedemann & $03 / 27 / 92$ \\
\hline 316 & TASK8-01-00-00 & Gary Luedemann & $03 / 27 / 92$ \\
\hline 317 & IDENT-01-00-00 & Gary Luedemann & $03 / 27 / 92$ \\
\hline 318 & OS9-01-00-00 & Gary Luedemann & $03 / 27 / 92$ \\
\hline 319 & FLEX-01-00-00 & Gary Luedemann & $03 / 27 / 92$ \\
\hline 320 & VISTA-01-00-00 & Gary Luedemann & $03 / 27 / 92$ \\
\hline 321 & VERSATERM-01-00-00 & M.G.Snow & $03 / 27 / 92$ \\
\hline 322 & EXCEL_MAC-01-00-00 & M.G.Snow & $03 / 27 / 92$ \\
\hline 323 & KALEIDAGRAPH-01-00-00 & M.G.Snow & $03 / 27 / 92$ \\
\hline 324 & $\mathrm{RS} / 1-01-00-00$ & M.G.Snow & $03 / 27 / 92$ \\
\hline 325 & GEO-PLUS-01-00-00 & M.G.Snow & $03 / 27 / 92$ \\
\hline 326 & SXRAY-01-00-00 & M.G.Snow & $03 / 27 / 92$ \\
\hline 327 & VISILOG-01-00-00 & M.G.Snow & $03 / 27 / 92$ \\
\hline 328 & CIAP-01-00-00 & M.G.Snow & $03 / 27 / 92$ \\
\hline 329 & FCIAI-ii-ini-(K) & M.G.Snow & (:; ; $; 92$ \\
\hline 330 & SUN_TOPS-01-00-00 & M.G.Snow & $03 / 27 / 92$ \\
\hline 331 & MAC_TORS-01-(0)-00 & M.G. Snow & $03 / 27 / 92$ \\
\hline 332 & IMIX-(1)-(00-00) & M.G.Snow & $03 / 27 / 92$ \\
\hline
\end{tabular}


SDDR STATUS ACCOUNTING FOR FOURTH QUARTER 1993

\begin{tabular}{|c|c|c|c|}
\hline ID & APPLICATION & REQUESTOR & DATE \\
\hline 333 & UNIX-01-00-00 & M.G. Snow & $03 / 27 / 92$ \\
\hline 334 & DATAFLEX_360-01-00-00 & M.G.Snow & $03 / 27 / 92$ \\
\hline 335 & $E S C P-01-00-00$ & M.G. Snow & $03 / 27 / 92$ \\
\hline 336 & VERSATERM-01-00-00 & Gary Luedemann & $03 / 27 / 92$ \\
\hline 337 & EXCEL_MAC-01-00-00 & Gary Luedemann & $03 / 27 / 92$ \\
\hline 338 & KALEIDAGRAPH-01-00-00 & Gary Luedemann & $03 / 27 / 92$ \\
\hline 339 & GEO-PLUS-01-00-00 & Gary Luedemann & $03 / 27 / 92$ \\
\hline 340 & SXRAY-01-00-00 & Gary Luedemann & $03 / 27 / 92$ \\
\hline 341 & VISILOG-01-00-00 & Gary Luedemann & $03 / 27 / 92$ \\
\hline 342 & CIAP-01-00-00 & Gary Luedemann & $03 / 27 / 92$ \\
\hline 343 & FCIAP-01-00-00 & Gary Luedemann & $03 / 27 / 92$ \\
\hline 344 & SUN_TOPS-01-00-00 & Gary Luedemann & $03 / 27 / 92$ \\
\hline 345 & MAC_TOPS-01-00-00 & Gary Luedemann & $03 / 27 / 92$ \\
\hline 346 & IMIX-01-00-00 & Gary Luedemann & $03 / 27 / 92$ \\
\hline 347 & UNIX-01-00-00 & Gary Luedemann & $03 / 27 / 92$ \\
\hline 348 & ADEM-01-00-00 & George Guthrie & $03 / 27 / 92$ \\
\hline 349 & SQ-01-00-00 & George Guthrie & $03 / 27 / 92$ \\
\hline 350 & TASK8-01-00-00 & George Guthrie & $03 / 27 / 92$ \\
\hline 351 & IDENT-01-00-00 & George Guthrie & $03 / 27 / 92$ \\
\hline 352 & OS9-01-00-00 & George Guthrie & $03 / 27 / 92$ \\
\hline 353 & FLEX-01-00-00 & George Guthrie & $03 / 27 / 92$ \\
\hline 354 & VISTA-01-00-00 & George Guthrie & $03 / 27 / 92$ \\
\hline 355 & VERSAIËỉivi-(ii-(i)-(n) & George Guthrie & $03 / 27 / 92$ \\
\hline 356 & EXCEL_MAC-01-00-00 & George Guthrie & $03 / 27 / 92$ \\
\hline 357 & KALEIDAGRAPH-(1)1-00-00 & George Guthrie & $03 / 27 / 92$ \\
\hline 358 & RS/1-(11-(10)-(10) & Ceorge Guthrie & $(13 / 27 / 92$ \\
\hline
\end{tabular}


SDDR STATUS ACCOUNTING FOR FOURTH QUARTER 1993

\begin{tabular}{|c|c|c|c|}
\hline ID & APPLICATION & REQUESTOR & DATE \\
\hline 359 & GEO-PLUS-01-00-00 & George Guthrie & $03 / 27 / 92$ \\
\hline 360 & SXRAY-01-00-00 & George Guthrie & $03 / 27 / 92$ \\
\hline 361 & VISILOG-01-00-00 & George Guthrie & $03 / 27 / 92$ \\
\hline 362 & CIAP-01-00-00 & George Guthrie & $03 / 27 / 92$ \\
\hline 363 & FCIAP-01-00-00 & George Guthrie & $03 / 27 / 92$ \\
\hline 364 & SUN_TOPS-01-00-00 & George Guthrie & $03 / 27 / 92$ \\
\hline 365 & MAC_TOPS- $01-00-00$ & George Guthrie & $03 / 27 / 92$ \\
\hline 366 & IMIX-01-00-00 & George Guthrie & $03 / 27 / 92$ \\
\hline 367 & UNIX-01-00-00 & George Guthrie & $03 / 27 / 92$ \\
\hline 368 & MAC_OS-01-00-00 & George Guthrie & $03 / 27 / 92$ \\
\hline 369 & VAX_VMS-01-00-00 & George Guthrie & $03 / 27 / 92$ \\
\hline 370 & DOS-01-00-00 & George Guthrie & $03 / 27 / 92$ \\
\hline 371 & FORTRAN_COMPILERS-01-00-00 & George Guthrie & $03 / 27 / 92$ \\
\hline 372 & ADEM-01-00-00 & Steven Reneau & $03 / 27 / 92$ \\
\hline 373 & SQ-01-00-00 & Steven Reneau & $03 / 27 / 92$ \\
\hline 374 & TASK8-01-00-00 & Steven Reneau & $03 / 27 / 92$ \\
\hline 375 & IDENT-01-00-00 & Steven Reneau & $03 / 27 / 92$ \\
\hline 376 & OS9-01-00-00 & Steven Reneau & $03 / 27 / 92$ \\
\hline 377 & FLEX-01-00-00 & Steven Reneau & $03 / 27 / 92$ \\
\hline 378 & MAC_OS-01-00-00 & Steven Reneau & $03 / 27 / 92$ \\
\hline 379 & VERSATERM-01-00-00 & Steven Reneau & $03 / 27 / 92$ \\
\hline 380 & EXCEL_MAC-01-00-00 & Steven Reneau & $03 / 27 / 92$ \\
\hline 381 & KALEIDAGRAPH-(01-(00-(0) & Steven Reneau & $013 / 27 / 92$ \\
\hline 382 & RS/1-01-00-00 & Steven Reneau & $03 / 27 / 92$ \\
\hline 383 & GEO-PLUS-(01-(0)-(10) & Steven Reneau & $03 / 27 / 92$ \\
\hline 384 & SXRAY-(1)1-(00-00) & Steven Reneau & $0.3 / 27 / 92$ \\
\hline
\end{tabular}




\section{SDDR STATUS ACCOUNTING FOR FOURTH QUARTER 1993}

\begin{tabular}{|c|c|c|c|}
\hline ID & APPLICATION & REQUESTOR & DATE \\
\hline 385 & VISILOG-01-00-00 & Steven Reneau & $03 / 27 / 92$ \\
\hline 386 & CIAP-01-00-00 & Steven Reneau & $03 / 27 / 92$ \\
\hline 387 & FCIAP-01-00-00 & Steven Reneau & $03 / 27 / 92$ \\
\hline 388 & SUN_TOPS-01-00-00 & Steven Reneau & $03 / 27 / 92$ \\
\hline 389 & MAC_TOPS-01-00-00 & Steven Reneau & $03 / 27 / 92$ \\
\hline 390 & IMIX-01-00-00 & Steven Reneau & $03 / 27 / 92$ \\
\hline 391 & UNIX-01-00-00 & Steven Reneau & $03 / 27 / 92$ \\
\hline 392 & FORTRAN_COMPILERS-01-00-00 & Steven Reneau & $03 / 27 / 92$ \\
\hline 393 & VAX_VMS-01-00-00 & Steven Reneau & $03 / 27 / 92$ \\
\hline 394 & DOS-01-00-00 & Steven Reneau & $03 / 27 / 92$ \\
\hline 395 & DATAFLEX_360-01-00-00 & Emily Kluk & $03 / 27 / 92$ \\
\hline 396 & ADEM-01-00-00 & Emily Kluk & $03 / 27 / 92$ \\
\hline 397 & TASK8-01-00-00 & Emily Kluk & $03 / 27 / 92$ \\
\hline 398 & OS9-01-00-00 & Emily Kluk & $03 / 27 / 92$ \\
\hline 399 & FLEX-01-00-00 & Emily Kluk & $03 / 27 / 92$ \\
\hline 400 & MAC_OS-01-00-00 & Emily Kluk & $03 / 27 / 92$ \\
\hline 401 & VERSATERM-01-00-00 & Emily Kluk & $03 / 27 / 92$ \\
\hline 402 & EXCEL_MAC-01-00-00 & Emily Kluk & $03 / 27 / 92$ \\
\hline 403 & KALEIDAGRAPH-01-00-00 & Emily Kluk & $03 / 27 / 92$ \\
\hline 404 & RS/1-01-00-00 & Emily Kluk & $03 / 27 / 92$ \\
\hline 405 & GEO-PLUS-01-00-00 & Emily Kluk & $03 / 27 / 92$ \\
\hline 406 & SXRAY $-01-00-00$ & Emily Kluk & $03 / 27 / 92$ \\
\hline 407 & VISILOG-(j1-(00-(0) & Emily Kluk & $03 / 27 / 92$ \\
\hline 408 & SUN_TOPS-01-00-00 & Emily Kluk & $03 / 27 / 92$ \\
\hline 409 & MAC_TOPS-01-00-00 & Emily Kluk & $03 / 27 / 92$ \\
\hline 410 & UNIX-(01-00)-00 & Emily Kluk & $(13 / 27 / 92$ \\
\hline
\end{tabular}


SDDR STATUS ACCOUNTING FOR FOURTH QUARTER 1993

\begin{tabular}{|c|c|c|c|}
\hline ID & APPLICATION & REQUESTOR & DATE \\
\hline 411 & VAX_VMS-01-00-00 & Emily Kluk & $03 / 27 / 92$ \\
\hline 412 & DOS-01-00-00 & Emily Kluk & $03 / 27 / 92$ \\
\hline 413 & FORTRAN_COMPILERS-01-00-00 & Emily Kluk & $03 / 27 / 92$ \\
\hline 414 & DIONEX_AI450-01-00-00 & E. Essington & $09 / 03 / 92$ \\
\hline 415 & DOS-01-00-00 & E. Essington & $09 / 03 / 92$ \\
\hline 416 & MS_WINDOWS-01-00-00 & E. Essington & $09 / 03 / 92$ \\
\hline 417 & MS_DOS-01-00-00 & E. Essington & $09 / 03 / 92$ \\
\hline 418 & MS_QUICKBASIC-01-00-00 & E. Essington & $09 / 03 / 92$ \\
\hline 419 & SAS_FOR_SUNX-01-00-00 & E. Essington & $09 / 03 / 92$ \\
\hline 420 & COHORT-01-00-00 & E. Essington & $09 / 03 / 92$ \\
\hline 421 & FORTRAN_COMPILERS-01-00-00 & E. Essington & $09 / 03 / 92$ \\
\hline 422 & QUATTRO_PRO-01-00-00 & E. Essington & $09 / 03 / 92$ \\
\hline 423 & PKZIP-01-00-00 & E. Essington & $09 / 03 / 92$ \\
\hline 424 & NLINISO.SAS & E. Essington & $10 / 08 / 92$ \\
\hline 425 & ESCP-01-00-00 & Emily Kluk & $03 / 27 / 92$ \\
\hline 426 & VISTA-01-00-00 & Emily Kluk & $03 / 27 / 92$ \\
\hline 427 & POSTSOFT-01-00-00 & Steve Chipera & $04 / 08 / 92$ \\
\hline 428 & COREL_DRAW-01-00-00 & Steve Chipera & $04 / 08 / 92$ \\
\hline 429 & BIO-RAD-01-00-00 & Steve Chipera & $04 / 08 / 92$ \\
\hline 430 & SPECTRALAB-01-00-00 & Steve Chipera & $04 / 08 / 92$ \\
\hline 431 & POSTSOFT- $-01-00-00$ & David Bish & $04 / 08 / 92$ \\
\hline 432 & COREL_DRAW-01-00-00 & David Bish & $04 / 08 / 92$ \\
\hline 433 & BIO-RAD-01-00-00 & David Bish & (lifils/yiz \\
\hline 434 & SPECTRALAB-01-(00-00 & David Bish & $04 / 08 / 92$ \\
\hline 4.35 & DIFFRACTINEL-(01-(1)-(00 & Steve Chipera & $04 / 20 / 92$ \\
\hline 436 & DIFFRACTINEL-(01-(0)-(0) & David Bish & $(44 / 20 / 92$ \\
\hline
\end{tabular}




\section{SDDR STATUS ACCOUNTING FOR FOURTH QUARTER 1993}

\begin{tabular}{|c|c|c|c|}
\hline ID & APPLICATION & REQUESTOR & DATE \\
\hline 437 & TABLE_CURVE-01-00-00 & Steve Chipera & $04 / 20 / 92$ \\
\hline 438 & TABLE_CURVE-01-00-00 & David Bish & $04 / 20 / 92$ \\
\hline 439 & PLAN_PERFECT-01-00-00 & June Fabryka-Martin & $04 / 02 / 92$ \\
\hline 440 & MS_QUICKBASIC-01-00-00 & Brent Newman & $04 / 06 / 92$ \\
\hline 441 & EM4105-01-00-00 & Barbara Carlos & $04 / 06 / 92$ \\
\hline 442 & MINFILE-01-00-00 & Barbara Carlos & $04 / 06 / 92$ \\
\hline 443 & DOS-01-00-00 & Schon Levy & $04 / 17 / 92$ \\
\hline 444 & $\mathrm{RS} / 1-01-00-00$ & Schon Levy & $04 / 17 / 92$ \\
\hline 445 & EM4105-01-00-00 & Schon Levy & $04 / 17 / 92$ \\
\hline 446 & ADEM-01-00-00 & Schon Levy & $04 / 17 / 92$ \\
\hline 447 & VISTA-01-00-00 & Schon Levy & $04 / 17 / 92$ \\
\hline 448 & TASK8-01-00-00 & Schon Levy & $04 / 17 / 92$ \\
\hline 449 & $S Q-01-00-00$ & Schon Levy & $04 / 17 / 92$ \\
\hline 450 & OS9-01-00-00 & Schon Levy & $04 / 17 / 92$ \\
\hline 451 & IDENT-01-00-00 & Schon Levy & $04 / 17 / 92$ \\
\hline 452 & FLEX-01-00-00 & Schon Levy & $04 / 17 / 92$ \\
\hline 453 & LCLSQ-01-00-00 & Steve Chipera & $05 / 01 / 92$ \\
\hline 454 & TGRAF-01-00-00 & Steve Chipera & $05 / 01 / 92$ \\
\hline 455 & PIZAZZ_PLUS-01-00-00 & Steve Chipera & $05 / 01 / 92$ \\
\hline 456 & LCLSQ-01-00-00 & David Bish & $05 / 01 / 92$ \\
\hline 457 & TGRAF-01-0(1)-00 & David Bish & $05 / 01 / 92$ \\
\hline 458 & PIZAZZ_PLUS-01-(0)-00 & David Bish & $05 / 01 / 92$ \\
\hline 4 & WVINEUWWS_EXCEL-(01-00-00 & R. Morley & $05 / 19 / 92$ \\
\hline 460 & WINDOWS_EXCEL-01-00-(0) & Brent Newman & $07 / 01 / 92$ \\
\hline 461 & CDFTOOLS-01-00-00 & Bruce Robinson & $07 / 21 / 92$ \\
\hline 462 & QUANT-01-(0)-00 & Steve Chipera & $10 / 27 / 92$ \\
\hline
\end{tabular}


SDDR STATUS ACCOUNTING FOR FOURTH QUARTER 1993

\begin{tabular}{|c|c|c|c|}
\hline ID & APPLICATION & REQUESTOR & DATE \\
\hline 463 & QUANT-01-00-00 & David Bish & $10 / 27 / 92$ \\
\hline 464 & MATHCAD-01-00-00 & F. Perry & $10 / 27 / 92$ \\
\hline 465 & SYSTAT-01-00-00 & F. Perry & $10 / 27 / 92$ \\
\hline 466 & WINDOWS_EXCEL-01-00-00 & F. Perry & $10 / 27 / 92$ \\
\hline 467 & IGPET-01-00-00 & F. Perry & $10 / 27 / 92$ \\
\hline 468 & AXUM-01-00-- & F. Perry & $10 / 27 / 92$ \\
\hline 469 & SURFACE_DISPLAY_SYSTEM-01-00-00 & F. Perry & $10 / 27 / 92$ \\
\hline 470 & DESIGNER-01-00-00 & F. Perry & $10 / 27 / 92$ \\
\hline 471 & SURFER-01-00-00 & F. Perry & $10 / 27 / 92$ \\
\hline 472 & SURFER-01-00-00 & R. Morley & $10 / 27 / 92$ \\
\hline 473 & SURFER-01-00-00 & C. Scherschel & $11 / 04 / 92$ \\
\hline 474 & WINDOWS_EXCEL-01-00-00 & L. Bowker & $11 / 04 / 92$ \\
\hline 475 & WINDOWS_EXCEL-01-00-00 & C. Scherschel & $11 / 04 / 92$ \\
\hline 476 & SURFER-01-00-00 & L. Bowker & $11 / 04 / 92$ \\
\hline 477 & QUATTRO_PRO-01-00-00 & June Fabryka-Martin & $12 / 10 / 92$ \\
\hline 478 & DICNEX_AI450-01-00-00 & June Fabryka-Martin & $12 / 10 / 92$ \\
\hline 479 & FCIAP-01-00-00 & Barbara Carlos & $01 / 05 / 93$ \\
\hline 480 & CIAP- $-01-00-00$ & Barbara Carlos & $01 / 05 / 93$ \\
\hline 481 & VISILOG-01-00-00 & Barbara Carlos & $01 / 05 / 93$ \\
\hline 482 & SXRAY_SUN-01-00-00 & Barbara Carlos & $01 / 05 / 93$ \\
\hline 483 & GEO-PLUS- $01-00-00$ & Barbara Carlos & $01 / 05 / 93$ \\
\hline 484 & GENPLOT-01-00-(0) & Bruce Robinson & $03 / 15 / 93$ \\
\hline 485 & SORBEQ-(11-00-(1)H & Bruce Robinson & $(13 / 15 / 43$ \\
\hline 486 & CRYSTAL_BALL_WINDOWS-01-(0)-(1) & F.Perry & $03 / 30 / 93$ \\
\hline 487 & FOX_PRO-01-00-00 & Rich Morley & $03 / 25 / 93$ \\
\hline 488 & QUICKBASIC_STDS-(01-(0)-(0) & Dave Morris & $(13 / 25 / 93$ \\
\hline
\end{tabular}


SDDR STATUS ACCOUNTING FOR FOURTH QUARTER 1993

\begin{tabular}{|c|c|c|c|}
\hline ID & APPLICATION & REQUESTOR & DATE \\
\hline \hline 489 & TRACRN-01-00-00 Probationary Release & Lynn Trease & $03 / 26 / 93$ \\
\hline 490 & VAX_VMS-01-00-00 & Robert Raymond & $07 / 01 / 93$ \\
\hline 491 & XRF-11-01-00-00 & Robert Raymond & $07 / 01 / 93$ \\
\hline 492 & PATASC-01-00-00 & Steve Chipera & $07 / 07 / 93$ \\
\hline 493 & PATASC-01-00-00 & George Guthrie & $07 / 07 / 93$ \\
\hline 494 & PATASC-01-00-00 & David Bish & $07 / 07 / 93$ \\
\hline 495 & LOTUS_123-01-00-00 & Giday WoldeGabriel & $07 / 12 / 93$ \\
\hline 496 & NEWMODF-01-00-00 & Steve Chipera & $07 / 22 / 93$ \\
\hline 497 & NEWMODF-01-00-00 & David Bish & $07 / 22 / 93$ \\
\hline 498 & dBASE_IV-01-00-00 & Andrew Burningham & $09 / 23 / 93$ \\
\hline
\end{tabular}


This page left intentionally blank 
Appendix D

Controlled Documents Issued in 1993 
DOCUMENT CONTROL STATUS REPORT FOR 1993

\begin{tabular}{|c|c|c|}
\hline NEW DOCUMENTS & REVISED DOCUMENTS & DELETED DOCUMENTS \\
\hline $\begin{array}{l}\text { EES-13 Environmental Safety and } \\
\text { Health Plan }\end{array}$ & $\begin{array}{l}\text { TWS-EES-DP-101, R1 was superseded by } \\
\text { LANL-EES-DP-101, R2, Sample/Specimen Collection, } \\
\text { Identification, and Control for Mineralogy-Petrology } \\
\text { Studies }\end{array}$ & $\begin{array}{l}\text { TWS-EES-DP-127, R0, Sample } \\
\text { Collection of Muck from } \\
\text { Excavation of the Exploratory } \\
\text { Shaft Facility }\end{array}$ \\
\hline Volcanism Field Safety Plan, R1 & $\begin{array}{l}\text { TWS-EES-13-DP-606, R1 was superseded by } \\
\text { LANL-EES13-DP-606, R2, Volcanism Field Studies }\end{array}$ & $\begin{array}{l}\text { LANL-EES-DP-605, Rl, } \\
\text { Preparation of Powders from } \\
\text { Rock Cinder and Ash Samples }\end{array}$ \\
\hline $\begin{array}{l}\text { EES-13 SOP for Operation of Truck- } \\
\text { Mounted Backhoe, R1 }\end{array}$ & $\begin{array}{l}\text { LANL-EES13-DP-608, R0 was superseded by } \\
\text { LANL-EES13-DP-608, R1, Procedure for Preparation of } \\
\text { Splits and Powders from Soil Samples }\end{array}$ & $\begin{array}{l}\text { TWS-QAS-QP-01.1, R2, } \\
\text { Interface Control Procedure }\end{array}$ \\
\hline $\begin{array}{l}\text { Excavation Plan for Volcanism Soil } \\
\text { Pits, R0 }\end{array}$ & $\begin{array}{l}\text { LANL-INC-DP-92, R0 was superseded by } \\
\text { LANL-INC-DP-92, R1, Sample Leaching to Extract } \\
\text { Soluble Chloride and Bromide }\end{array}$ & \\
\hline $\begin{array}{l}\text { EES-1 Standard Operating Procedure } \\
\text { for Safety During Field Work }\end{array}$ & $\begin{array}{l}\text { LANL-INC-DP-95, R0 was superseded by } \\
\text { LANL-INC-DP-95, R1, Preparation of Samples for } \\
\text { Chlorine-36 Analysis }\end{array}$ & \\
\hline $\begin{array}{l}\text { LANL-EES-DP-134, R0 } \\
\text { INEL X-ray Diffraction Procedure }\end{array}$ & $\begin{array}{l}\text { LANL-EES-DP-111, R2 was superseded by } \\
\text { LANL-EES-DP-111, R3, RIGAKU } 3064 \text { X-ray } \\
\text { Fluorescence Spectrometer Operating System }\end{array}$ & \\
\hline $\begin{array}{l}\text { LANL-EES-DP-3.27, R0, Use of a Flow } \\
\text { Cytometer to Detirmine Particle } \\
\text { Concentrations in Solution }\end{array}$ & $\begin{array}{l}\text { LANL-EES-13-DP- } 609, \text { R0 was superseded by } \\
\text { LANL-EES-13-DP-609, R1, Balance and Weight } \\
\text { Calibration by LANL Standard and Calibration Group }\end{array}$ & \\
\hline $\begin{array}{l}\text { LANL-EES-DP-3:28, R0, Use of an } \\
\text { lon-Selective Elettrode to Determine } \\
\text { lon Concentrations in Solution }\end{array}$ & & \\
\hline
\end{tabular}




\begin{tabular}{||l|l|l||}
\hline \multicolumn{1}{|c|}{ NEW DOCUMENTS } & REVISED DOCUMENTS & DELETED DOCUMENTS \\
\hline \hline $\begin{array}{l}\text { SVA-2, Prolog Variance for DCL } \\
\text { Files/Unix Shell Scripts }\end{array}$ & & \\
\hline $\begin{array}{l}\text { SVA-S, Users M: nuals for reuse } \\
\text { components }\end{array}$ & & \\
\hline $\begin{array}{l}\text { SVA-15, Allow Prologs to be optional } \\
\text { for Support Modules }\end{array}$ & & \\
\hline $\begin{array}{l}\text { SAV-16, Wordin! } \text { Clarification for } \\
\text { VVP Template }\end{array}$ & & \\
\hline $\begin{array}{l}\text { SVA-9, Use of Pre-Existing } \\
\text { Development Sofiware }\end{array}$ & & \\
\hline $\begin{array}{l}\text { SVA-10, SCF-89' Certification of } \\
\text { SS/ACS without : VVR }\end{array}$ & & \\
\hline $\begin{array}{l}\text { SVA-12, Minim! } m \text { Documentation } \\
\text { Requirements }\end{array}$ & & \\
\hline $\begin{array}{l}\text { SVA-13, Allow Limited Modification } \\
\text { of ACS }\end{array}$ & & \\
\hline
\end{tabular}


APPENDIX E

Los Alamos Deficiency Database 


\section{Introduction}

In the following pages, deficiencies are categorized by document, which is listed at the top of each page. Deficiencies are also grouped by year. Deficiencies can be identified by referring to the abbreviations listed below.

Deficiencies are compiled from Project Office and internal audit and survey reports, stop work order and conflict resolution logs, and the Los Alamos deficiency report data base. Deficiencies fixed during audits and surveys are included (identified in the "FIXED" column).

\section{Abbreviations}

- SDR-562 Standard Deficiency Report 562, issued by Project Office.

- CAR-92-001

Corrective Action Report 001, issued by Project Office. 92 is the fiscal year (1992) deficiency was written.

DR $135 \quad$ Los Alamos Internal Deficiency Report \#135.

R5, 18.2.7 R5 is version of procedure; 18.2.7 is section of procedure violated.

-91-008-1 Los Alamos internal audit 91-008, conducted in 1991. Deficiency \#1 was fixed during the audit.

- YA-90-01-7 Project Office audit 90-01, conducted in 1990.

Deficiency \#7 was fixed during the audit.

- SR-91-014 Project Office Survey 91-014, conducted in 1991.

Deficiency \#14 was fixed during the survey.

- SWO-LA07 Los Alamos stop work order \#07.

- CR-001 Los Alamos conflict resolution \#01. 
Table I. Detailed Procedures (DPs)

\begin{tabular}{|c|c|c|c|c|c|c|c|}
\hline \multicolumn{2}{|c|}{1990} & \multicolumn{2}{|c|}{1991} & \multicolumn{2}{|c|}{1992} & \multicolumn{2}{|c|}{1993} \\
\hline Deficiency & Fixed & Deficiency & Fixed & Deficiency & Fixed & Deficiency & Fixed \\
\hline & $\begin{array}{l}\text { YA- } \\
90-01-12 \\
\text { DP 07, R3 }\end{array}$ & $\begin{array}{l}\text { DR } 140 \\
\text { DP } 06 \\
\text { DR } 160 \\
\text { DP } 35 \\
\text { DR 174 } \\
\text { DP } 607, \text { Ro } \\
\text { DR } 178 \\
\text { DP 401, R0 } \\
\text { DR 187 } \\
\text { DP 35, R1 }\end{array}$ & $\begin{array}{l}91-002-3 \\
\text { DP } 606, \text { R1 } \\
91-008-4 \\
\text { DP } 15 \\
91-10-2 \\
\text { DP } 607, \\
\text { RO, } 6.6\end{array}$ & $\begin{array}{l}\text { DR 199 } \\
\text { DP 607, } \\
\text { RO, 2.0, } \\
4.0 \\
\text { DR } 201 \\
\text { DP 608, R0 } \\
\text { DR 206 } \\
\text { DP } 87, \text { R1 } \\
\text { DR 206 } \\
\text { DP 90, R0 } \\
\text { DR 206 } \\
\text { DP } 87, \text { R2 } \\
\text { DR 206 } \\
\text { DP 96, R0 } \\
\text { DR 206 } \\
\text { DP 95, RO } \\
\text { DR 206 } \\
\text { DP 90, R1 }\end{array}$ & & $\begin{array}{l}\text { DR } 219 \\
\text { DP } 101, \mathrm{R} 2 \\
9.0 \\
\text { DR } 232 \\
\text { DP } 79, \mathrm{R} 1\end{array}$ & $\begin{array}{l}93-04-04 \\
\text { DP 606, R2 } \\
\text { 93-04-02 } \\
\text { DP 607, } \\
\text { RO, 6.1 } \\
\text { 93-12-03 } \\
\text { DP } 86, \text { RO }\end{array}$ \\
\hline \multicolumn{8}{|l|}{ Total } \\
\hline 0 & 1 & 5 & 3 & 8 & 0 & 2 & 3 \\
\hline
\end{tabular}


Table II. QAPP (R5)

\begin{tabular}{|c|c|c|c|c|c|c|c|}
\hline \multicolumn{2}{|c|}{1990} & \multicolumn{2}{|c|}{1991} & \multicolumn{2}{|c|}{1992} & \multicolumn{2}{|c|}{1993} \\
\hline Deficiency & Fixed & Deficiency & Fixed & Deficiency & Fixed & Deficiency & Fixed \\
\hline $\begin{array}{l}\text { DR } 011 \\
\text { v4.3 } \\
\text { DR } 012 \\
\text { v4.3 } \\
\text { DR } 013 \\
\text { v4.3 } \\
\text { DR } 017 \\
\text { v4.3, } 2.1 .1 \\
\text { DR } 024 \\
\text { v4.4, 3.1.9 } \\
\text { SDR } 511 \\
\text { Sec. } 1 \& 2 \\
\text { SDR } 513 \\
\text { v4.3, } 2.1 .1 \\
\text { DR } 053 \\
\text { v4.4 } \\
\text { DR } 077 \\
\text { v4.4, 3.1.3 } \\
\text { DR } 115 \\
\text { v4.4 }\end{array}$ & & $\begin{array}{l}\text { DR } 135 \\
\text { v5 } \\
\text { DR } 137 \\
\text { v5 } \\
\text { DR } 143 \\
\text { v5 } \\
\text { DR } 151 \\
\text { v5, 18.2.7 } \\
\text { CAR- } \\
91-041, v 5 \\
\text { DR } 174 \\
\text { R5 }\end{array}$ & & $\begin{array}{l}\text { CAR- } \\
92-057, v 5\end{array}$ & & $\begin{array}{c}\text { No } \\
\text { deficiencies } \\
\text { in } 1993\end{array}$ & \\
\hline $\begin{array}{l}\text { Total } \\
\qquad 10\end{array}$ & 0 & 6 & 0 & 1 & 0 & 0 & 0 \\
\hline
\end{tabular}


Table III. QP-01.1 (R2)

\begin{tabular}{|c|c|c|c|c|c|c|c|}
\hline \multicolumn{2}{|c|}{1990} & \multicolumn{2}{|c|}{1991} & \multicolumn{2}{|c|}{1992} & \multicolumn{2}{|c|}{1993} \\
\hline Deficiency & Fixed & Deficiency & Fixed & Deficiency & Fixed & Deficiency & Fixed \\
\hline $\begin{array}{l}\text { DR } 026 \\
\text { R2, } 6.2 \\
\\
\text { DR } 028 \\
\text { R2, } 1.1 \\
\text { DR } 91 \\
\text { R2, 6.1-6.2 }\end{array}$ & & & $\begin{array}{l}91-003-3 \\
\text { R0, } 6.2 \\
91-008-1 \\
\text { R2 }\end{array}$ & $\begin{array}{c}\text { No } \\
\text { deficiencies } \\
\text { in } 1992\end{array}$ & & $\begin{array}{c}\text { CAR- } \\
93-049 \\
\text { - Deleted in } \\
12 / 93\end{array}$ & \\
\hline Total & & & & & & & \\
\hline 3 & 0 & 0 & 2 & 0 & 0 & 1 & 0 \\
\hline
\end{tabular}

Table IV. QP-01.2 (R1)

\begin{tabular}{|c|c|c|c|c|c|c|c|}
\hline \multicolumn{2}{|c|}{1990} & \multicolumn{2}{|c|}{1991} & \multicolumn{2}{|c|}{1992} & \multicolumn{2}{|c|}{1993} \\
\hline Deficiency & Fixed & Deficiency & Fixed & Deficiency & Fixed & Deficiency & Fixed \\
\hline $\begin{array}{l}\text { DR } 013 \\
\text { RO, } 6.3 \\
\\
\text { DR } 016 \\
\text { RO, } 6.2 \\
\text { DR } 093 \\
\text { RO }\end{array}$ & $\begin{array}{l}\text { YA- } \\
90-01-7 \\
\text { RO }\end{array}$ & $\begin{array}{c}\text { No } \\
\text { deficiencies } \\
\text { in } 1991\end{array}$ & & $\begin{array}{c}\text { No } \\
\text { deficiencies } \\
\text { in } 1993\end{array}$ & & $\begin{array}{c}\text { No } \\
\text { deficiencies } \\
\text { in } 1993\end{array}$ & \\
\hline Total & & & & & & & \\
\hline 3 & 1 & 0 & 0 & 0 & 0 & 0 & 0 \\
\hline
\end{tabular}


Table V. QP-01.3 (R1)

\begin{tabular}{|c|c|c|c|c|c|c|c||}
\hline \multicolumn{2}{|c|}{1990} & \multicolumn{2}{c|}{1991} & \multicolumn{2}{c|}{1992} & \multicolumn{2}{c||}{1993} \\
\hline Deficiency & Fixed & Deficiency & Fixed & Deficiency & Fixed & Deficiency & Fixed \\
\hline \hline $\begin{array}{c}\text { No } \\
\text { deficiencies } \\
\text { in 1990 }\end{array}$ & $\begin{array}{c}\text { No } \\
\text { deficiencies } \\
\text { in 1991 }\end{array}$ & & $\begin{array}{c}\text { No } \\
\text { deficiencies } \\
\text { in 1992 }\end{array}$ & & $\begin{array}{c}\text { No } \\
\text { deficiencies } \\
\text { in 1993 }\end{array}$ & \\
\hline $\begin{array}{c}\text { Total } \\
0\end{array}$ & 0 & 0 & 0 & 0 & 0 & 0 & 0 \\
\hline
\end{tabular}

Table VI. QP-02.3 (R1)

\begin{tabular}{||c|c|c|c|c|c|c|c||}
\hline \multicolumn{2}{|c|}{1990} & \multicolumn{2}{c|}{1991} & \multicolumn{2}{c|}{1992} & \multicolumn{2}{c||}{1993} \\
\hline Deficiency & Fixed & Deficiency & Fixed & Deficiency & Fixed & Deficiency & Fixed \\
\hline \hline $\begin{array}{c}\text { No } \\
\text { deficiencies } \\
\text { in 1990 }\end{array}$ & & $\begin{array}{c}\text { No } \\
\text { deficiencies } \\
\text { in 1997 }\end{array}$ & & $\begin{array}{c}\text { No } \\
\text { deficiencies } \\
\text { in 1992 }\end{array}$ & & $\begin{array}{c}\text { No } \\
\text { deficiencies } \\
\text { in 1993 }\end{array}$ & \\
\hline $\begin{array}{c}\text { Total } \\
0\end{array}$ & 0 & 0 & 0 & 0 & 0 & & \\
\hline
\end{tabular}

Table VII. QP-02.4 (R1)

\begin{tabular}{|c|c|c|c|c|c|c|c|}
\hline \multicolumn{2}{|c|}{1990} & \multicolumn{2}{|c|}{1991} & \multicolumn{2}{|c|}{1992} & \multicolumn{2}{|c|}{1993} \\
\hline Deficiency & Fixed & Deficiency & Fixed & Deficiency & Fixed & Deficiency & Fixed \\
\hline $\begin{array}{l}\text { DR 115, } \\
\text { RO, Sec. } \\
5.1\end{array}$ & & $\begin{array}{l}\text { DR 132, } \\
\text { RO, } 5.1\end{array}$ & & $\begin{array}{c}\text { No } \\
\text { deficiencies } \\
\text { in } 1992 \\
\end{array}$ & & $\begin{array}{c}\text { No } \\
\text { deficiencies } \\
\text { in } 1993 \\
\end{array}$ & \\
\hline Total & & & & & & & \\
\hline 1 & 0 & 1 & 0 & 0 & 0 & 0 & 0 \\
\hline
\end{tabular}


Table VIII. QP-02.5 (R1)

\begin{tabular}{|c|c|c|c|c|c|c|c|}
\hline \multicolumn{2}{|c|}{1990} & \multicolumn{2}{|c|}{1991} & \multicolumn{2}{|c|}{1992} & \multicolumn{2}{|c|}{1993} \\
\hline Deficiency & Fixed & Deficiency & Fixed & Deficiency & Fixed & Deficiency & Fixed \\
\hline $\begin{array}{l}\text { DR 034, } \\
\text { RO, 6.2-6.5 } \\
\text { DR 095, RO } \\
\text { DR 096, RO } \\
\text { DR 103, RO } \\
\text { SWO-LA02, } \\
\text { RO }\end{array}$ & & $\begin{array}{l}\text { DR 136, RO } \\
\text { DR 145, } \\
\text { RO, 6.3 } \\
\text { DR 163, } \\
\text { RO, 6.1, } \\
6.1 .1 \\
\text { DR 169, } \\
\text { R0, 6.2 } \\
\text { DR 177, } \\
\text { R1, 6.1.2 }\end{array}$ & $\begin{array}{l}91-001-1 \\
\text { R0, 6.2.1 } \\
91-002-2 \\
\text { R0, } 6.2 \\
91-013-1 \\
\text { R0, 6.2.4 } \\
\text { YA- } \\
91-03-1 \\
\text { RO } \\
91-11-1, \text { RO } \\
6.2 .3 \\
91-12-1, \text { RO } \\
6.2 .3 \\
91-12-2, \text { RO } \\
6.2 .4\end{array}$ & & $\begin{array}{l}92-006-1 \\
\text { R1,6.1.4 } \\
92-006-4 \\
\text { R1,6.1.6 } \\
\text { YA-92-19- } \\
03 \\
\text { R1 } \\
\text { YA- } \\
92-19-01 \\
\text { R1 } \\
\text { YA- } \\
92-19-02 \\
\text { R1 }\end{array}$ & $\begin{array}{l}\text { DR 227, } \\
\text { R1, 6.1.1 } \\
\text { DR 229, } \\
\text { R1, 6.2.3 } \\
\text { DR 231, } \\
\text { R1, 6.2.3 }\end{array}$ & $\begin{array}{l}93-09- \\
01, \mathrm{R} 1, \\
6.1 .2 \\
93-10- \\
01, \mathrm{R} 1, \\
6.1 .1, .2 \\
93-12- \\
01 \mathrm{R} 1, \\
6.1 .2\end{array}$ \\
\hline $\begin{array}{r}\text { Total } \\
5\end{array}$ & 0 & 5 & 7 & 0 & 5 & 3 & 3 \\
\hline
\end{tabular}

Table IX. QP-02.6 (R1)

\begin{tabular}{|c|c|c|c|c|c|}
\hline \multicolumn{2}{|c|}{1990} & \multicolumn{2}{|c|}{1991} & \multicolumn{2}{|c|}{1992} \\
\hline Deficiency & Fixed & Deficiency & Fixed & Deficiency & Fixed \\
\hline $\begin{array}{l}\text { DR 032, } \\
\text { RO, 5.3.1 }\end{array}$ & & $\begin{array}{l}\text { DR } 173, \\
\text { R1, } 6.1\end{array}$ & $\begin{array}{l}91-11-2, \\
\text { R1, } 6.5\end{array}$ & & $\begin{array}{l}92-006-2 \\
\mathrm{R} 1,6.1 .5\end{array}$ \\
\hline $\begin{array}{l}\text { DR 034, } \\
\text { RO, } 6.1 .3\end{array}$ & & & $\begin{array}{l}91-12-3, \\
R 1,6.1 .6,\end{array}$ & & $\begin{array}{l}92-006-2 \\
\mathrm{R} 1,6.1 .3\end{array}$ \\
\hline DR 095, RO & & & & & $\begin{array}{l}\text { Superceded } \\
\text { by } Q P \text { - }\end{array}$ \\
\hline DR 096, RO & & & & & $2.11, R O$ \\
\hline DR 103, RO & & & & & \\
\hline $\begin{array}{l}\text { SWO-LAO2, } \\
\text { RO }\end{array}$ & & & & & \\
\hline Total & & & & & \\
\hline 6 & 0 & 1 & 2 & 0 & 2 \\
\hline
\end{tabular}


Table X. QP-02.7 (R1)

\begin{tabular}{|c|c|c|c|c|c|c|c|}
\hline \multicolumn{2}{|c|}{1990} & \multicolumn{2}{|c|}{1991} & \multicolumn{2}{|c|}{1992} & \multicolumn{2}{|c|}{1993} \\
\hline Deficiency & Fixed & Deficiency & Fixed & Deficiency & Fixed & Deficiency & Fixed \\
\hline $\begin{array}{l}\text { DR 027 } \\
\text { RO, 6.4.4.2 } \\
\text { DR } 033 \\
\text { RO, 5.5 } \\
\text { DR } 051 \\
\text { RO, 6.2.1 } \\
\text { DR } 052 \\
\text { RO, } 6.2 .1 \\
\text { DR } 068 \\
\text { RO, } 6.2 \\
\text { DR } 074 \\
\text { RO, } 6.2 \\
\text { DR } 092 \\
\text { RO, } 6.2 \\
\text { DR } 095 \\
\text { RO } \\
\text { DR } 096 \\
\text { RO } \\
\text { DR } 100 \\
\text { RO, } 6.2 .1 \\
\text { DR } 103 \\
\text { RO, } 6.2 \\
\text { DR } 113 \\
\text { RO, } 6.2 \\
\text { SWO-LA02 } \\
\text { RO }\end{array}$ & & $\begin{array}{l}\text { DR } 145 \\
\text { R1, } 6.2 \\
\text { DR } 156 \\
\text { R1, 6.2 } \\
\text { DR } 157 \\
\text { R1, 6.4.3 }\end{array}$ & $\begin{array}{l}91-006-1 \\
\text { R1, Att. } 1 \\
91-12-3 \\
\text { R1, } 6.4 .5\end{array}$ & $\begin{array}{l}\text { DR } 207 \\
\text { R1, } 6.2 \\
\text { DR } 213 \\
\text { R1, 6.2 } \\
\text { DR } 208 \\
\text { R1 } \\
\text { DR } 205 \\
\text { R1 } \\
\text { DR } 216 \\
\text { R1, } 6.2\end{array}$ & $\begin{array}{l}92-001-1 \\
\mathrm{R} 1,6.5 .6 \\
92-002-4 \\
\mathrm{R} 1, \\
6.4 .7, .8 \\
92-004-3 \\
\mathrm{R} 1,6.4 .7 \\
92-006-4 \\
\mathrm{R} 1,6.4 .7 \\
92-10-001 \\
\mathrm{R} 1,6.2 \\
92-13-001 \\
\mathrm{R} 1,6.2\end{array}$ & $\begin{array}{l}\text { DR } 219 \mathrm{R} 1 \text {, } \\
6.2 \\
\text { DR } 221 \mathrm{R} 1 \text {, } \\
6.2 \\
\text { DR } 214 \mathrm{R} 1 \text {, } \\
9.0 \\
\text { DR } 213 \mathrm{R} 1 \text {, } \\
6.2\end{array}$ & $\begin{array}{l}93-05- \\
01, R 1, \\
6.2 \\
93-10- \\
02, R 1, \\
6.2\end{array}$ \\
\hline $\begin{array}{l}\text { Total } \\
13 \\
\end{array}$ & 0 & 3 & 2 & 5 & 6 & 4 & 2 \\
\hline
\end{tabular}

Table XI. QP-02.8 (R0)

\begin{tabular}{||c|c|c|c|c|c||}
\hline \multicolumn{2}{|c|}{1990} & \multicolumn{2}{c|}{1991} & \multicolumn{2}{c||}{1992} \\
\hline Deficiency & Fixed & Deficiency & Fixed & Deficiency & Fixed \\
\hline $\begin{array}{c}\text { No } \\
\text { deficiencies } \\
\text { in 1990 }\end{array}$ & $\begin{array}{c}\text { No } \\
\text { deficiencies } \\
\text { in 1991 }\end{array}$ & & $\begin{array}{c}\text { No } \\
\text { deficiencies } \\
\text { in 1992 }\end{array}$ & $\begin{array}{c}\text { Procedure } \\
\text { deleted }\end{array}$ \\
\hline Total & & 0 & 0 & 0 & 0 \\
0
\end{tabular}


Table XII. QP-02.9 (R1)

\begin{tabular}{|c|c|c|c|c|c|c|c|}
\hline \multicolumn{2}{|c|}{1990} & \multicolumn{2}{|c|}{1991} & \multicolumn{2}{|c|}{1992} & \multicolumn{2}{|c|}{1993} \\
\hline Deficiency & Fixed & Deficiency & Fixed & Deficiency & Fixed & Deficiency & Fixed \\
\hline $\begin{array}{l}\text { DR 095, RO } \\
\text { DR 096, RO } \\
\text { DR 103, RO } \\
\text { SWO-LA02, } \\
\text { RO }\end{array}$ & & & $\begin{array}{l}91-12-5 \\
\text { RO, } \\
6.1 .4\end{array}$ & $\begin{array}{l}\text { DR } 200 \\
\text { RO, } 5.1,6.1\end{array}$ & $\begin{array}{l}92-003-1 \\
\text { Ro, } 6.3\end{array}$ & $\begin{array}{l}\text { DR } 230 \text { R1, } \\
6.1\end{array}$ & $\begin{array}{l}93-07- \\
01, \mathrm{R} 1, \\
6.1\end{array}$ \\
\hline $\begin{array}{l}\text { Total } \\
\qquad 4 \\
\end{array}$ & 0 & 0 & 1 & 1 & 1 & 1 & 1 \\
\hline
\end{tabular}

Table XIII. QP-2.11 (R1)

\begin{tabular}{||c|c|c|c||}
\hline \multicolumn{2}{|c|}{1992} & \multicolumn{2}{c|}{1993} \\
\hline Deficiency & Fixed & Deficiency & Fixed \\
\hline \hline $\begin{array}{c}\text { No } \\
\text { deficiencies } \\
\text { in 1992 }\end{array}$ & & & $93-07-02$ \\
& & & $\mathrm{R} 1,6.2 .4$ \\
& & & $93-09-02$ \\
& & & $\mathrm{R} 1,6.1 .1$ \\
& & & $93-10-03$ \\
\hline Total & & & $\mathrm{R} 1,6.1 .2$ \\
\hline 0 & 0 & 0 & \\
\hline
\end{tabular}


Table XIV. OP-03.2 (R0)

\begin{tabular}{|c|c|c|c|c|c|}
\hline \multicolumn{2}{|c|}{1990} & \multicolumn{2}{|c|}{1991} & \multicolumn{2}{|c|}{1992} \\
\hline Deficiency & Fixed & Deficiency & Fixed & Deficiency & Fixed \\
\hline $\begin{array}{l}\text { DR } 024 \\
\text { RO, } 6.3 .1\end{array}$ & $\begin{array}{l}\text { YA-90-01-2 } \\
\text { RO }\end{array}$ & $\begin{array}{l}\text { DR } 146 \\
\text { RO, } 6.1 .1\end{array}$ & $\begin{array}{l}91-001-02 \\
R O, 6.2 .1\end{array}$ & $\begin{array}{l}\text { DR } 199 \text { Ro, } \\
5.0\end{array}$ & $\begin{array}{l}92-002-5 \\
R 0,6.1 .1\end{array}$ \\
\hline $\begin{array}{l}\text { DR } 067 \\
\text { RO, } 2.0\end{array}$ & $\begin{array}{l}\text { SDR } 512 \\
\text { RO, 3.2.1 }\end{array}$ & $\begin{array}{l}\text { DR } 152 \\
\text { RO, } 6.3 .1\end{array}$ & $\begin{array}{l}91-002-2 \\
\text { RO, 6.2.1 }\end{array}$ & $\begin{array}{l}\text { DR } 197 \text { Ro, } \\
7.0\end{array}$ & $\begin{array}{l}\text { Superceded } \\
\text { by } Q P\end{array}$ \\
\hline $\begin{array}{l}\text { DR } 080 \\
\text { R0, } 7.0\end{array}$ & & $\begin{array}{l}\text { DR } 162 \\
\text { RO, } 7.0\end{array}$ & $\begin{array}{l}\text { SR-91-014 } \\
\text { RO }\end{array}$ & $\begin{array}{l}\text { DR } 222 \text { Ro, } \\
7.0\end{array}$ & \\
\hline $\begin{array}{l}\text { DR } 081 \\
\text { R0, } 5.2\end{array}$ & & $\begin{array}{l}\text { DR } 184 \\
\text { RO, } 6.3 .1\end{array}$ & $\begin{array}{l}91-12-6 \\
\mathrm{RO}, 6.2 .2 \text {, }\end{array}$ & & \\
\hline $\begin{array}{l}\text { DR } 082 \\
\text { RO, } 7.0\end{array}$ & & & & & \\
\hline $\begin{array}{l}\text { DR } 105 \\
\text { RO, } 6.3 .1\end{array}$ & & & & & \\
\hline $\begin{array}{l}\text { DR } 120 \\
\text { Ro, } 2.0 \\
\end{array}$ & & & & & \\
\hline Total & & & & & \\
\hline 7 & 2 & 4 & 4 & 3 & 1 \\
\hline
\end{tabular}

Table XV. QP-03.3 (R0)

\begin{tabular}{|c|c|c|c|c|c|}
\hline \multicolumn{2}{|c|}{1990} & \multicolumn{2}{|c|}{1991} & \multicolumn{2}{|c|}{1992} \\
\hline Deficiency & Fixed & Deficiency & Fixed & Deficiency & Fixed \\
\hline $\begin{array}{l}\text { DR } 069 \\
\text { RO, } 5.2 \\
\text { DR } 070 \\
\text { R0, } 6.5 .1 \\
\text { DR } 072 \\
\text { RO } \\
\text { DR } 073 \\
\text { RO, } 5.2 \\
\text { DR } 074 \\
\text { RO } \\
\text { DR } 075 \\
\text { RO } \\
\text { DR } 077 \\
\text { RO }\end{array}$ & $\begin{array}{l}\text { YA-90-01-1 } \\
\text { RO }\end{array}$ & $\begin{array}{l}\text { DR } 147 \\
\text { RO, } 6.0, \& \\
6.2 .6 \\
\text { DR } 153 \\
\text { RO, } 3.2 .3, \\
\& 3.1 .2 \\
\text { DR } 162 \\
\text { RO, } 6.2 .4 \\
\text { DR } 172 \\
\text { RO }\end{array}$ & & & $\begin{array}{l}\text { Superceded } \\
\text { by } Q P \text { - } \\
3.23, R O\end{array}$ \\
\hline $\begin{array}{r}\text { Total } \\
7 \\
\end{array}$ & 1 & 4 & 0 & 0 & 0 \\
\hline
\end{tabular}


Table XVI. QP-03.5 (R1)

\begin{tabular}{|c|c|c|c|c|c|c|c|}
\hline \multicolumn{2}{|c|}{1990} & \multicolumn{2}{|c|}{1991} & \multicolumn{2}{|c|}{1992} & \multicolumn{2}{|c|}{1993} \\
\hline Deficiency & Fixed & Deficiency & Fixed & Deficiency & Fixed & Deficiency & Fixed \\
\hline 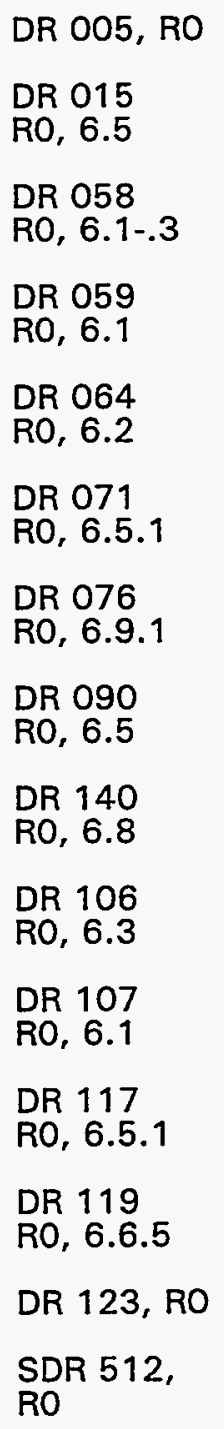 & & 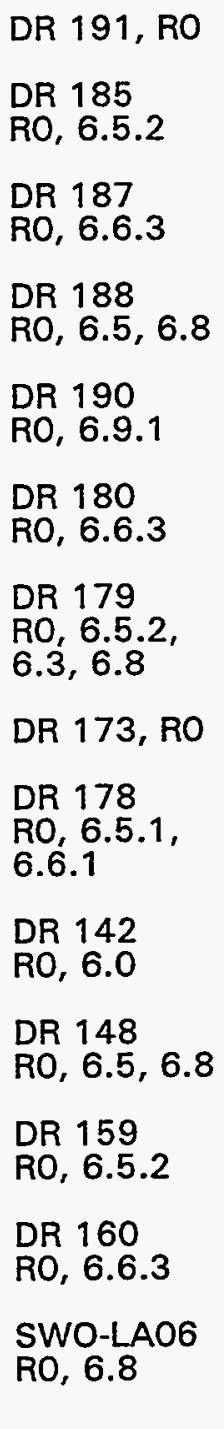 & $\begin{array}{l}91-003-4 \\
\text { RO, } 6.1 \\
91-004- \\
1,2,3 \\
\text { RO, } 6.5 .2, \\
6.8 \\
91-008-2 \\
\text { RO, 6.6.5, } \\
6.6 .3 \\
91-013-2, \\
3 \text { RO, } \\
6.6 .5, \\
6.6 .3 \\
\text { YA- } \\
91-03-2 \\
\text { RO } \\
91-014-1, \\
\text { RO } \\
91-015-1 \\
\text { RO, 6.1 } \\
91-10-1 \\
\text { RO, 6.8 } \\
91-11-3 \\
\text { RO, } 6.5 .2 \\
91-12-7 \\
\text { RO, } 6.3, \\
6.8\end{array}$ & $\begin{array}{l}\text { DR } 199 \\
\text { RO, } 5.0 \\
\text { CAR- } \\
92-058 \\
\text { R0, } 6.9 .1\end{array}$ & $\begin{array}{l}92-08-001 \\
\text { R0, } 6.6 .3 \\
92-001-2 \\
\text { Ro, } 6.8 \\
92-002-1 \\
\text { RO, } 6.1 \text {, } \\
6.8 \\
92-002-2 \\
\text { R0, 6.6.3 } \\
92-002-3 \\
\text { RO, } 6.2 \text {, } \\
6.8 \\
92-003-3 \\
\text { RO } 6.1 \text {, } \\
.2, .3, .8 \\
92-004-1 \\
\text { R0, } 6.6 .5 \\
92-004-2 \\
\text { Ro, } 6.1\end{array}$ & $\begin{array}{l}\text { DR } 220 \text { R1, } \\
6.5 .3\end{array}$ & $\begin{array}{l}93-04-01 \\
\text { R1, 6.4 } \\
93-06-01 \\
\text { R1, } \\
6.5 .3 .1 \\
93-12-02 \\
\text { R1, 6.2, } \\
.3, .4\end{array}$ \\
\hline $\begin{array}{l}\text { Total } \\
15 \\
\end{array}$ & 0 & 14 & 10 & 2 & 8 & 1 & 3 \\
\hline
\end{tabular}


Table XVII. QP-03.7 (R0)

\begin{tabular}{|c|c|c|c|c|c|c|c||}
\hline \multicolumn{2}{|c|}{1990} & \multicolumn{2}{c|}{1991} & \multicolumn{2}{c|}{1992} & \multicolumn{2}{c||}{1993} \\
\hline Deficiency & Fixed & Deficiency & Fixed & Deficiency & Fixed & Deficiency & Fixed \\
\hline $\begin{array}{c}\text { No } \\
\text { deficiencies } \\
\text { in 1990 }\end{array}$ & $\begin{array}{c}\text { No } \\
\text { deficiencies } \\
\text { in 1991 }\end{array}$ & & $\begin{array}{c}\text { No } \\
\text { deficiencies } \\
\text { in 1992 }\end{array}$ & & $\begin{array}{c}\text { No } \\
\text { deficiencies } \\
\text { in 1993 }\end{array}$ & \\
\hline $\begin{array}{c}\text { Total } \\
0\end{array}$ & 0 & 0 & 0 & 0 & 0 & 0 & 0 \\
\hline
\end{tabular}

Table XVIII. QP-03.14 (R0)

\begin{tabular}{||c|c|c|c|c|c||}
\hline \multicolumn{2}{|c|}{1990} & \multicolumn{2}{c|}{1991} & \multicolumn{2}{c||}{1992} \\
\hline Deficiency & Fixed & Deficiency & Fixed & Deficiency & Fixed \\
\hline $\begin{array}{c}\text { No } \\
\text { deficiencies } \\
\text { in 1990 }\end{array}$ & $\begin{array}{c}\text { No } \\
\text { deficiencies } \\
\text { in 1991 }\end{array}$ & & & $\begin{array}{c}\text { Superceded } \\
\text { by QP-3.24 }\end{array}$ \\
\hline Total & 0 & 0 & 0 & 0 & 0 \\
\hline
\end{tabular}

Table XIX. QP-03.15 (RO)

\begin{tabular}{||l|c|c|c|c|c||}
\hline \multicolumn{2}{|c|}{1990} & \multicolumn{2}{c|}{1991} & \multicolumn{2}{c||}{1992} \\
\hline Deficiency & Fixed & Deficiency & Fixed & Deficiency & Fixed \\
\hline $\begin{array}{l}\text { DR 029 } \\
\text { R1, 4.0 }\end{array}$ & $\begin{array}{c}\text { No } \\
\text { deficiencies } \\
\text { in } 1991\end{array}$ & & & $\begin{array}{c}\text { Superceded } \\
\text { by QP-3.24 }\end{array}$ \\
\hline Total & & 0 & 0 & 0 & 0 \\
\hline 1
\end{tabular}

Table XX. OP-03.16 (R0)

\begin{tabular}{|c|c|c|c|c|c||}
\hline \multicolumn{2}{|c|}{1990} & \multicolumn{2}{c|}{1991} & \multicolumn{2}{c|}{1992} \\
\hline Deficiency & Fixed & Deficiency & Fixed & Deficiency & Fixed \\
\hline $\begin{array}{c}\text { No } \\
\text { deficiencies } \\
\text { in 1990 }\end{array}$ & & $\begin{array}{c}\text { No } \\
\text { deficiencies } \\
\text { in 1991 }\end{array}$ & & & $\begin{array}{c}\text { Superceded } \\
\text { by QP-3.25 }\end{array}$ \\
\hline $\begin{array}{c}\text { Total } \\
0\end{array}$ & 0 & 0 & 0 & 0 & 0 \\
\hline
\end{tabular}


Table XXI. SQAP (RO)

\begin{tabular}{|c|c|c|c|c|c|c|c|}
\hline \multicolumn{2}{|c|}{1990} & \multicolumn{2}{|c|}{1991} & \multicolumn{2}{|c|}{1992} & \multicolumn{2}{|c|}{1993} \\
\hline Deficiency & Fixed & Deficiency & Fixed & Deficiency & Fixed & Deficiency & Fixed \\
\hline $\begin{array}{c}\text { Note } \\
\text { Issued in } \\
1989 \\
\text { SWO-LAO1 }\end{array}$ & & $\begin{array}{l}\text { DR } 155 \\
\text { RO, } 7.2 .7\end{array}$ & & $\begin{array}{l}\text { DR } 195 \\
\text { RO, 5.2.2.3 } \\
\text { DR } 209 \\
\text { RO, } \\
7.2 .11 .2 \\
\text { DR } 213, \text { RO } \\
\text { DR } 214, \text { RO } \\
\text { SWO-LAO8 } \\
\text { RO, Fig. } 1 \\
\text { DR } 215 \\
\text { RO, } 6.2 .9\end{array}$ & & $\begin{array}{l}\text { DR } 222 \text { Ro, } \\
6.0\end{array}$ & \\
\hline $\begin{array}{l}\text { Total } \\
0\end{array}$ & 0 & 1 & 0 & 6 & 0 & 1 & 0 \\
\hline
\end{tabular}

Table XXII. QP-3.17 (RO)

\begin{tabular}{||c|c|c|c|l|l|l|l||}
\hline \multicolumn{2}{|c|}{1990} & \multicolumn{2}{c|}{1991} & \multicolumn{2}{c|}{1992} & \multicolumn{2}{c||}{1993} \\
\hline Deficiency & Fixed & Deficiency & Fixed & Deficiency & Fixed & Deficiency & Fixed \\
\hline deficiencies \\
in 1990
\end{tabular}


Table XXIII. QP-3.18 (R0)

\begin{tabular}{||c|c|c|c|c|c|c|c||}
\hline \multicolumn{2}{|c|}{1990} & \multicolumn{2}{c|}{1991} & \multicolumn{2}{c|}{1992} & \multicolumn{2}{c||}{1993} \\
\hline Deficiency & Fixed & Deficiency & Fixed & Deficiency & Fixed & Deficiency & Fixed \\
\hline $\begin{array}{c}\text { No } \\
\text { deficiencies } \\
\text { in 1990 }\end{array}$ & & $\begin{array}{c}\text { No } \\
\text { deficiencies } \\
\text { in 1991 }\end{array}$ & & $\begin{array}{c}\text { DR 213, Ro } \\
\text { DR 214, Ro } \\
\text { DR 215, Ro }\end{array}$ & & $\begin{array}{c}\text { No } \\
\text { deficiencies } \\
\text { in 1993 }\end{array}$ & \\
\hline Total & 0 & 0 & 0 & 3 & & & 0 \\
0
\end{tabular}

Table XXIV. QP-3.19 (RO)

\begin{tabular}{|c|c|c|c|c|c|c|c|}
\hline \multicolumn{2}{|c|}{1990} & \multicolumn{2}{|c|}{1991} & \multicolumn{2}{|c|}{1992} & \multicolumn{2}{|c|}{1993} \\
\hline Deficiency & Fixed & Deficiency & Fixed & Deficiency & Fixed & Deficiency & Fixed \\
\hline $\begin{array}{c}\text { No } \\
\text { deficiencies } \\
\text { in } 1990\end{array}$ & & $\begin{array}{c}\text { No } \\
\text { deficiencies } \\
\text { in } 1991\end{array}$ & & $\begin{array}{l}\text { DR 213, RO } \\
\text { DR 214, RO } \\
\text { DR 215, RO } \\
\text { SWO-LA08 } \\
\text { RO }\end{array}$ & & $\begin{array}{c}\text { No } \\
\text { deficiencies } \\
\text { in } 1993\end{array}$ & \\
\hline Total & & & & & & & \\
\hline 0 & 0 & 0 & 0 & 4 & 0 & 0 & 0 \\
\hline
\end{tabular}

Table XXV. QP-3.20 (R0)

\begin{tabular}{|c|c|c|c|c|c|c|c|}
\hline \multicolumn{2}{|c|}{1990} & \multicolumn{2}{|c|}{1991} & \multicolumn{2}{|c|}{1992} & \multicolumn{2}{|c|}{1993} \\
\hline Deficiency & Fixed & Deficiency & Fixed & Deficiency & Fixed & Deficiency & Fixed \\
\hline $\begin{array}{c}\text { No } \\
\text { deficiencies } \\
\text { in } 1990\end{array}$ & & $\begin{array}{c}\text { No } \\
\text { deficiencies } \\
\text { in } 1991\end{array}$ & & $\begin{array}{l}\text { CAR- } \\
92-019 \\
\text { RO, 6.2.4.1 } \\
\text { DR } 209 \\
\text { RO, } \\
6.2 .10 .1 .1 \\
\text { DR 213, RO } \\
\text { DR 214, RO } \\
\text { DR 215, RO } \\
\text { SWO-LAO8 } \\
\text { RO }\end{array}$ & & $\begin{array}{l}\text { DR } 222 \text { Ro, } \\
6.0\end{array}$ & \\
\hline Total & & & & & & & \\
\hline 0 & 0 & 0 & 0 & 6 & 0 & 1 & 0 \\
\hline
\end{tabular}


Table XXVI. QP-3.21 (R0)

\begin{tabular}{|c|c|c|c|c|c|c|c|}
\hline \multicolumn{2}{|c|}{1990} & \multicolumn{2}{|c|}{1991} & \multicolumn{2}{|c|}{1992} & \multicolumn{2}{|c|}{1993} \\
\hline Deficiency & Fixed & Deficiency & Fixed & Deficiency & Fixed & Deficiency & Fixed \\
\hline & $\begin{array}{l}\text { YA- } \\
91-03-3 \\
\text { RO }\end{array}$ & $\begin{array}{c}\text { No } \\
\text { deficiencies } \\
\text { in } 1991\end{array}$ & & $\begin{array}{l}\text { DR 212, } \\
\text { RO, } \\
6.3 .3 .2 .3 \\
\text { DR 213, RO } \\
\text { DR 214, RO } \\
\text { DR 215, RO } \\
\text { SWO-LAO8 } \\
\text { RO }\end{array}$ & $\begin{array}{l}92- \\
17-001 \\
\text { RO, } \\
6.3 .3 .2 .3\end{array}$ & $\begin{array}{l}\text { DR } 222 \text { Ro, } \\
6.0\end{array}$ & \\
\hline Total & & & & & & & \\
\hline 0 & 1 & 0 & 0 & 5 & 1 & 1 & 0 \\
\hline
\end{tabular}

Table XXVII. OP-3.22 (R0)

\begin{tabular}{|c|c|c|c|c|c|c|c|}
\hline \multicolumn{2}{|c|}{1990} & \multicolumn{2}{|c|}{1991} & \multicolumn{2}{|c|}{1992} & \multicolumn{2}{|c|}{1993} \\
\hline Deficiency & Fixed & Deficiency & Fixed & Deficiency & Fixed & Deficiency & Fixed \\
\hline $\begin{array}{c}\text { No } \\
\text { deficiencies } \\
\text { in } 1990\end{array}$ & & $\begin{array}{c}\text { No } \\
\text { deficiencies } \\
\text { in } 1991\end{array}$ & & $\begin{array}{l}\text { DR 213, RO } \\
\text { DR 215, } \\
\text { RO, 6.2.9 } \\
\text { SWO-LAO8 } \\
\text { RO }\end{array}$ & & & \\
\hline Total & & & & & & & \\
\hline 0 & 0 & 0 & 0 & 3 & 0 & 0 & 0 \\
\hline
\end{tabular}

Table XXVIII. QP-3.23 (R0)

\begin{tabular}{||c|c|c|c|c|c|c|c||}
\hline \multicolumn{2}{|c|}{1990} & \multicolumn{2}{c|}{1991} & \multicolumn{2}{c|}{1992} & \multicolumn{2}{c|}{1993} \\
\hline Deficiency & Fixed & Deficiency & Fixed & Deficiency & Fixed & Deficiency & Fixed \\
\hline $\begin{array}{c}\text { No } \\
\text { deficiencies } \\
\text { in 1990 }\end{array}$ & $\begin{array}{c}\text { No } \\
\text { deficiencies } \\
\text { in 1991 }\end{array}$ & & $\begin{array}{c}\text { DR 210, Ro } \\
\text { Att. 3 }\end{array}$ & & $\begin{array}{l}\text { DR 222 R0, } \\
7.0\end{array}$ \\
\hline $\begin{array}{c}\text { Total } \\
0\end{array}$ & 0 & 0 & 0 & 1 & 0 & & 0 \\
\hline
\end{tabular}


Table XXIX. QP-3.24 (R0)

\begin{tabular}{||c|c|c|c||}
\hline \multicolumn{2}{|c|}{1992} & \multicolumn{2}{c||}{1993} \\
\hline Deficiency & Fixed & Deficiency & Fixed \\
\hline $\begin{array}{c}\text { No } \\
\text { deficiencies } \\
\text { in } 1992\end{array}$ & & $\begin{array}{c}\text { No } \\
\text { deficiencies } \\
\text { in } 1993\end{array}$ & \\
\hline Total & & 0 & 0 \\
0 & 0 & 0 & 0 \\
\hline
\end{tabular}

Table XXX. QP-3.25 (RO)

\begin{tabular}{||c|c|c|c||}
\hline \hline \multicolumn{2}{|c|}{1992} & \multicolumn{2}{c|}{1993} \\
\hline Deficiency & Fixed & Deficiency & Fixed \\
\hline $\begin{array}{c}\text { No } \\
\text { deficiencies } \\
\text { in 1992 }\end{array}$ & & & $\begin{array}{l}93-01-01 \\
\text { RO, } 6.3 .3, \\
7.1 .1\end{array}$ \\
\hline Total & & & \\
0 & 0 & 0 & 1 \\
\hline
\end{tabular}


Table XXXI. QP-4.1 (R2)

\begin{tabular}{|c|c|c|c|c|c|}
\hline \multicolumn{2}{|c|}{1990} & \multicolumn{2}{|c|}{1991} & \multicolumn{2}{|c|}{1992} \\
\hline Deficiency & Fixed & Deficiency & Fixed & Deficiency & Fixed \\
\hline $\begin{array}{l}\text { DR 004, R2 } \\
\text { DR 006, R1 } \\
\text { DR 018, R2 } \\
\text { DR 019, R2 } \\
\text { DR 021, R0 } \\
\text { DR } 022 \\
R 2,1.0 \\
\text { DR } 023 \\
R 2,2.0 \\
\text { DR } 035 \\
R 2,6.3 \\
\text { DR } 036 \\
R 2,7.1 \\
\text { DR } 037 \\
R 2,7.1 .7 \\
\text { DR } 061 \\
R 0,6.3 .2 \\
\text { DR } 062 \\
R 2,7.1 .7 \\
\text { DR } 063 \\
R 2,6.1 .1 .2 \\
\text { DR } 065 \\
R 2,7.1 .7 \\
\text { DR } 066 \\
R 2,7.1 .5 \\
\text { DR } 078 \\
R 2,6.3 \\
\text { DR } 085 \\
R 2,6.2 \\
\text { DR } 108 \\
R 2,6.3 \\
\text { DR } 113, R 2 \\
\text { SDR } 491, \\
R 2 \\
\text { SDR } 515 \\
R 2,6.4 \\
\end{array}$ & $\begin{array}{l}\text { YA-90-01-4 } \\
\text { R2, } 6.4\end{array}$ & $\begin{array}{l}\text { DR } 150 \\
\text { R2, } 6.6\end{array}$ & & $\begin{array}{l}\text { Superceded } \\
\text { by QPS-4.4, } \\
\text { and }-4.5\end{array}$ & \\
\hline $\begin{array}{l}\text { Total } \\
21 \\
\end{array}$ & 1 & 1 & 0 & 0 & 0 \\
\hline
\end{tabular}


Table XXXII. OP-4.2 (R2)

\begin{tabular}{|c|c|c|c|c|c|}
\hline \multicolumn{2}{|c|}{1990} & \multicolumn{2}{|c|}{1991} & \multicolumn{2}{|c|}{1992} \\
\hline Deficiency & Fixed & Deficiency & Fixed & Deficiency & Fixed \\
\hline $\begin{array}{l}\text { DR } 083 \\
\text { R2, } 5.0 \\
\text { DR } 084 \\
\text { R2, } 5.0 \\
\end{array}$ & & $\begin{array}{c}\text { No } \\
\text { deficiencies } \\
\text { in } 1991\end{array}$ & & $\begin{array}{c}\text { No } \\
\text { deficiencies } \\
\text { in } 1992\end{array}$ & $\begin{array}{l}\text { Superceded } \\
\text { by } Q P S-4.4 \\
\text { and }-4.5\end{array}$ \\
\hline $\begin{array}{l}\text { Total } \\
2\end{array}$ & 0 & 0 & 0 & 0 & 0 \\
\hline
\end{tabular}

Table XXXIII. QP-4.3 (R1)

\begin{tabular}{|c|c|c|c|c|c|}
\hline \multicolumn{2}{|c|}{1990} & \multicolumn{2}{|c|}{1991} & \multicolumn{2}{|c|}{1992} \\
\hline Deficiency & Fixed & Deficiency & Fixed & Deficiency & Fixed \\
\hline $\begin{array}{l}\text { DR 003, R1 } \\
\text { DR 020, R1 }\end{array}$ & $\begin{array}{l}\text { YA-90-01-3 } \\
\text { R1 } \\
\text { YA-90-01-6 } \\
\text { R1 }\end{array}$ & $\begin{array}{l}\text { CR-001, R1 } \\
\text { DR } 166 \\
\text { R1, } 6.1,6.3\end{array}$ & & $\begin{array}{c}\text { No } \\
\text { deficiencies } \\
\text { in } 1992\end{array}$ & $\begin{array}{l}\text { Superceded } \\
\text { by } Q P_{S-4.4} 4 \\
\text { and }-4.5\end{array}$ \\
\hline $\begin{array}{l}\text { Total } \\
2\end{array}$ & 2 & 2 & 0 & 0 & 0 \\
\hline
\end{tabular}

Table XXXIV. QP-4.4 (R1)

\begin{tabular}{|c|c|c|c|c|c|c|c|}
\hline \multicolumn{2}{|c|}{1990} & \multicolumn{2}{|c|}{1991} & \multicolumn{2}{|c|}{1992} & \multicolumn{2}{|c|}{1993} \\
\hline Deficiency & Fixed & Deficiency & Fixed & Deficiency & Fixed & Deficiency & Fixed \\
\hline $\begin{array}{c}\text { No } \\
\text { deficiencies } \\
\text { in } 1990\end{array}$ & & $\begin{array}{l}\text { DR } 139 \\
\text { RO, } 6.7 \\
\text { CAR- } \\
92-001 \\
\text { RO } \\
\text { DR } 175 \\
\text { RO, 6.5, } \\
6.2, \& 6.1 \\
\text { DR } 182 \\
\text { RO, } 2.0 \\
\end{array}$ & $\begin{array}{l}\text { YA- } \\
92-01-1 \\
\text { RO }\end{array}$ & & $\begin{array}{l}92-10-002 \\
\mathrm{R} 1,6.2\end{array}$ & & $\begin{array}{l}93-12-04 \\
R 1,6.2, \\
.7 \\
93-09-03 \\
R 1,6.5 .1 \\
93-10-04 \\
R 1,6.3, \\
6.5 .1\end{array}$ \\
\hline $\begin{array}{r}\text { Total } \\
0\end{array}$ & 0 & 4 & 1 & 0 & 1 & 0 & 3 \\
\hline
\end{tabular}


Table XXXV. QP-4.5 (R2)

\begin{tabular}{|c|c|c|c|c|c|c|c|}
\hline \multicolumn{2}{|c|}{1990} & \multicolumn{2}{|c|}{1991} & \multicolumn{2}{|c|}{1992} & \multicolumn{2}{|c|}{1993} \\
\hline Deficiency & Fixed & Deficiency & Fixed & Deficiency & Fixed & Deficiency & Fixed \\
\hline $\begin{array}{c}\text { Not } \\
\text { applicable }\end{array}$ & & $\begin{array}{l}\text { DR } 149 \\
\text { RO, } 6.1 .1 \\
\text { SWO-LAO5, } \\
\text { RO } \\
\text { CAR- } \\
92-001 \\
\text { RO } \\
\text { DR } 182 \\
\text { RO, } 4.2 \\
\end{array}$ & & $\begin{array}{c}\text { No } \\
\text { deficiencies } \\
\text { in } 1992\end{array}$ & & $\begin{array}{l}\text { DR } 224 \text { R2, } \\
6.3\end{array}$ & \\
\hline $\begin{array}{r}\text { Total } \\
0 \\
0\end{array}$ & 0 & 4 & 0 & 0 & 0 & 1 & 0 \\
\hline
\end{tabular}

Table XXXVI. QP-5.1 (RO)

\begin{tabular}{|c|c|c|c|}
\hline \multicolumn{2}{|c|}{1990} & \multicolumn{2}{|c|}{1991} \\
\hline Deficiency & Fixed & Deficiency & Fixed \\
\hline $\begin{array}{l}\text { DR 002, R3 } \\
\text { DR 009 } \\
\text { R3, } 6.4 \\
\text { DR } 010 \\
\text { R3, 6.4 } \\
\text { DR 041 } \\
\text { R3, } 7.2 \\
\text { DR } 047 \\
\text { R3, } 6.2, \& \\
6.3\end{array}$ & & $\begin{array}{c}\text { No } \\
\text { deficiencies } \\
\text { in } 1991\end{array}$ & $\begin{array}{l}\text { Superceded } \\
\text { by } Q P-06.2\end{array}$ \\
\hline $\begin{array}{l}\text { Total } \\
\qquad 5\end{array}$ & 0 & 0 & 0 \\
\hline
\end{tabular}


Table XXXVII. OP-5.2 (R0)

\begin{tabular}{||l|c|c|c||}
\hline \multicolumn{2}{|c|}{1990} & \multicolumn{2}{c||}{1991} \\
\hline Deficiency & Fixed & Deficiency & Fixed \\
\hline \hline DR 007 & & $\begin{array}{c}\text { No } \\
\text { deficiencies } \\
\text { in 1991 }\end{array}$ & $\begin{array}{c}\text { Superceded } \\
\text { by QP-06.3 }\end{array}$ \\
R2, 5.2 & & & \\
R2, 7.0 & & & \\
DR 144, R2 & & & 0 \\
\hline Total & & 0 & \\
3 & 0 & & \\
\hline
\end{tabular}

Table XXXVIII. QP-6.1 (R5)

\begin{tabular}{|c|c|c|c|c|c|c|c|}
\hline \multicolumn{2}{|c|}{1990} & \multicolumn{2}{|c|}{1991} & \multicolumn{2}{|c|}{1992} & \multicolumn{2}{|c|}{1993} \\
\hline Deficiency & Fixed & Deficiency & Fixed & Deficiency & Fixed & Deficiency & Fixed \\
\hline $\begin{array}{l}\text { DR } 001 \\
R 1,5.2 \\
\text { DR } 030 \\
R 1,5.2 \\
\text { DR } 039 \\
\text { R1, 5.2 } \\
\text { DR } 045 \\
\text { R1, } 6.5 \\
\text { DR } 046 \\
\text { R1, } 6.5 \\
\text { DR } 116 \\
\text { R1, } 6.3 \\
\text { DR } 124 \\
\text { R2, } 6.3 .2 \\
\text { DR } 122 \\
\text { R0, } \\
6.2 .12 .1 \\
\end{array}$ & & $\begin{array}{l}\text { DR 161, R2 } \\
\text { DR 168 } \\
\text { R2, 6.3.3.2 } \\
\text { DR 174 } \\
\text { R3, 5.7 } \\
\text { DR } 189 \\
\text { R2, } 4.2\end{array}$ & $\begin{array}{l}91-001-03 \\
\mathrm{R} 2,6.3 .3 \\
91-003-05 \\
\mathrm{R} 2,5.4\end{array}$ & $\begin{array}{l}\text { DR } 196 \\
\text { R1, 6.3.3 }\end{array}$ & $\begin{array}{l}\text { YA- } \\
92-12-01 \text {, } \\
\text { R3, } 6.5\end{array}$ & $\begin{array}{l}\text { DR } 232 \\
\text { R5, } 6.1 .1\end{array}$ & $\begin{array}{l}93-12-05 \\
R 5,6.3 \\
93-09-04 \\
R 5,9.0\end{array}$ \\
\hline $\begin{array}{l}\text { Total } \\
\qquad 8\end{array}$ & 0 & 4 & 2 & 1 & 1 & 1 & 2 \\
\hline
\end{tabular}


Table XXXIX. OP-6.2 (R1)

\begin{tabular}{|c|c|c|c|c|c|c|c|}
\hline \multicolumn{2}{|c|}{1990} & \multicolumn{2}{|c|}{1991} & \multicolumn{2}{|c|}{1992} & \multicolumn{2}{|c|}{1993} \\
\hline Deficiency & Fixed & Deficiency & Fixed & Deficiency & Fixed & Deficiency & Fixed \\
\hline $\begin{array}{c}\text { No } \\
\text { deficiencies } \\
\text { in } 1990\end{array}$ & & $\begin{array}{c}\text { No } \\
\text { deficiencies } \\
\text { in } 1991\end{array}$ & & $\begin{array}{l}\text { DR } 198 \\
\text { R1, } 6.25 \\
\text { DR } 201 \\
\text { RO, } 6.2 .6 \\
\text { DR } 213 \\
\text { RO, } 9.0 \\
\text { DR } 214 \\
\text { RO, } 7.0 \\
\text { DR } 215 \\
\text { RO, } 6.2 .9 \\
\end{array}$ & & $\begin{array}{l}\text { DR } 217 \text { R1, } \\
6.2 .2 \\
\text { DR } 226 \mathrm{R} 1 \text {, } \\
6.1 .1\end{array}$ & \\
\hline $\begin{array}{l}\text { Total } \\
0\end{array}$ & 0 & 0 & 0 & 5 & 0 & 2 & 0 \\
\hline
\end{tabular}

Table XL. QP-6.3 (RO)

\begin{tabular}{|c|c|c|c|c|c|c|c|}
\hline \multicolumn{2}{|c|}{1990} & \multicolumn{2}{|c|}{1991} & \multicolumn{2}{|c|}{1992} & \multicolumn{2}{|c|}{1993} \\
\hline Deficiency & Fixed & Deficiency & Fixed & Deficiency & Fixed & Deficiency & Fixed \\
\hline $\begin{array}{c}\text { No } \\
\text { deficiencies } \\
\text { in } 1990\end{array}$ & & $\begin{array}{l}\text { DR 144, Ro } \\
\text { DR } 161 \\
\text { RO, } \\
6.2 .10 .2 \\
\text { DR } 189 \\
\text { RO, } \\
6.2 .10 .2\end{array}$ & & $\begin{array}{l}\text { DR } 201 \\
\text { Ro, } 6.2 .6 \\
\text { DR } 206 \\
\text { Ro, } 6.1,6.2 \\
6.2 .6\end{array}$ & & $\begin{array}{l}\text { DR } 221 \\
\text { RO, } 9.1\end{array}$ & $\begin{array}{l}93-02- \\
02, \mathrm{RO}, \\
6.2\end{array}$ \\
\hline $\begin{array}{l}\text { Total } \\
\qquad 0\end{array}$ & 0 & 3 & 0 & 2 & 0 & 1 & 1 \\
\hline
\end{tabular}

Table XLI. OP-08.1 (R2)

\begin{tabular}{|c|c|c|c|c|c|c|c|}
\hline \multicolumn{2}{|c|}{1990} & \multicolumn{2}{|c|}{1991} & \multicolumn{2}{|c|}{1992} & \multicolumn{2}{|c|}{1993} \\
\hline Deficiency & Fixed & Deficiency & Fixed & Deficiency & Fixed & Deficiency & Fixed \\
\hline $\begin{array}{l}\text { DR 038 } \\
\text { R0, } 7.1 \\
\text { DR 094 } \\
\text { R1, } 6.2 .1 \\
\text { DR } 125 \\
\text { R1, } 6.2 .1 \\
\end{array}$ & & $\begin{array}{l}\text { CAR- } \\
92-002 \\
R 1,6.4\end{array}$ & & & $\begin{array}{l}92-13- \\
001, \mathrm{R} 2 \\
92-13- \\
002, \mathrm{R} 2, \\
6.3 .2\end{array}$ & $\begin{array}{c}\text { No } \\
\text { deficiencies } \\
\text { in } 1993\end{array}$ & \\
\hline $\begin{array}{l}\text { Total } \\
\qquad 3\end{array}$ & 0 & 1 & 0 & 0 & 2 & 0 & 0 \\
\hline
\end{tabular}


Table XLII. OP-08.2 (R0)

\begin{tabular}{||c|c|c|c||}
\hline \multicolumn{2}{|c|}{1990} & \multicolumn{2}{c|}{1991} \\
\hline Deficiency & Fixed & Deficiency & Fixed \\
\hline \hline $\begin{array}{c}\text { No } \\
\text { deficiencies } \\
\text { in 1990 }\end{array}$ & & DR 154 & Superceded \\
& & RO, 6.1 & by OP-08.3 \\
& & DR 167 & \\
\hline RO, 6.1 & \\
\hline Total & & & \\
0 & 0 & 2 & 0 \\
\hline
\end{tabular}

Table XLIII. QP-08.3 (R0)

\begin{tabular}{||c|c|c|c|c|c|c|c||}
\hline \multicolumn{2}{|c|}{1990} & \multicolumn{2}{c|}{1991} & \multicolumn{2}{c|}{1992} & \multicolumn{2}{c||}{1993} \\
\hline $\begin{array}{c}\text { Deficiency } \\
\begin{array}{c}\text { Not } \\
\text { applicable }\end{array}\end{array}$ & Fixed & Deficiency & Fixed & Deficiency & Fixed & Deficiency & Fixed \\
\hline Total & $\begin{array}{c}\text { Not } \\
\text { applicable }\end{array}$ & & $\begin{array}{c}\text { No } \\
\text { deficiencies } \\
\text { in 1992 }\end{array}$ & & $\begin{array}{c}\text { DR 225 R0, } \\
6.1 .2,6.2 .1\end{array}$ & \\
0
\end{tabular}


Table XLIV. QP-12.1 (R6)

\begin{tabular}{|c|c|c|c|c|c|c|c|}
\hline \multicolumn{2}{|c|}{1990} & \multicolumn{2}{|c|}{1991} & \multicolumn{2}{|c|}{1992} & \multicolumn{2}{|c|}{1993} \\
\hline Deficiency & Fixed & Deficiency & Fixed & Deficiency & Fixed & Deficiency & Fixed \\
\hline $\begin{array}{l}\text { DR } 025 \\
\text { R4, } 6.7\end{array}$ & YA- & $\begin{array}{l}\text { DR } 137 \\
\text { R4, } 6.7\end{array}$ & $\begin{array}{l}91-003-2 \\
R 4,6.6\end{array}$ & $\begin{array}{l}\text { DR } 216 \\
\text { R6, } 9.0\end{array}$ & $\begin{array}{l}92-001-3 \\
R 4,7.1\end{array}$ & $\begin{array}{l}\text { DR } 216 \text { R6, } \\
9.0\end{array}$ & $\begin{array}{l}93-04-03 \\
\text { R6, } 6.2\end{array}$ \\
\hline $\begin{array}{l}\text { DR } 051 \\
\text { R4, CR140 }\end{array}$ & & $\begin{array}{l}\text { DR } 141 \\
\text { R4, } 2.0\end{array}$ & $\begin{array}{l}91-008-3 \\
\mathrm{R} 4,6.1 .1 \\
64\end{array}$ & $\begin{array}{l}\text { DR } 199 \\
\text { R4, } 2.0\end{array}$ & $\begin{array}{l}92-10-003 \\
R 6,6.0\end{array}$ & $\begin{array}{l}\text { DR } 228 \text { R6, } \\
6.4\end{array}$ & $\begin{array}{l}93-09-05 \\
\text { R6, } \\
6.4 .3 .2\end{array}$ \\
\hline $\begin{array}{l}\text { DR } 053 \\
\text { R4, } 6.7\end{array}$ & & $\begin{array}{l}\text { DR } 160 \\
\text { R4, } 5.5\end{array}$ & YA- & $\begin{array}{l}\text { DR } 203 \mathrm{R} 6, \\
6.4 .4 .2 \mathrm{a}\end{array}$ & & & \\
\hline $\begin{array}{l}\text { DR } 054 \\
\text { R4, } 6.7\end{array}$ & & $\begin{array}{l}\text { CAR- } \\
92-003\end{array}$ & & $\begin{array}{l}\text { DR } 208 \\
\text { R6, } 6.2 .1 \text {, }\end{array}$ & & & \\
\hline DR 055 & & $n 4,0.0$ & & 6.2 .3 & & & \\
\hline R4, 6.7 & & $\begin{array}{l}\text { DR } 171 \\
\text { R4, } 6.7\end{array}$ & & & & & \\
\hline R4, 6.7 & & DR 176 & & & & & \\
\hline $\begin{array}{l}\text { DR } 099 \\
\text { R4, } 5.2 \\
6.1 .1\end{array}$ & & $\begin{array}{l}\text { DR } 187 \\
\text { R4, } 5.5\end{array}$ & & & & & \\
\hline $\begin{array}{l}\text { DR } 101 \\
\text { R4, } 6.3 .2\end{array}$ & & $\begin{array}{l}\text { DR } 192 \\
\text { R4, } 6.3\end{array}$ & & & & & \\
\hline DR 100, R4 & & DR 193 & & & & & \\
\hline $\begin{array}{l}\text { DR } 102 \\
\text { R4, } 6.7\end{array}$ & & 6.4 & & & & & \\
\hline $\begin{array}{l}\text { DR } 109 \\
\text { R4, } 4.9 \\
6.1 .1\end{array}$ & & & & & & & \\
\hline $\begin{array}{l}\text { DR } 110 \\
\text { R4, } 7.1\end{array}$ & & & & & & & \\
\hline $\begin{array}{l}\text { DR } 112 \\
\text { R4, } 4.5 \\
4.9,6.4\end{array}$ & & & & & & & \\
\hline $\begin{array}{l}\text { DR } 126 \\
\text { R4, } 7.1\end{array}$ & & & & & & & \\
\hline $\begin{array}{l}\text { DR } 128 \\
\text { R4, } 6.7\end{array}$ & & & & & & & \\
\hline $\begin{array}{l}\text { SDR } 490 \\
R 3,4.8 \\
\end{array}$ & & & & & & & \\
\hline Total & & & & & & & \\
\hline 16 & 1 & 9 & 3 & 4 & 2 & 2 & 2 \\
\hline
\end{tabular}


Table XLV. QP-13.1 (R2)

\begin{tabular}{||c|c|c|c|c|c|c|c||}
\hline \multicolumn{2}{|c|}{1990} & \multicolumn{2}{c|}{1991} & \multicolumn{2}{c|}{1992} & \multicolumn{2}{c|}{1993} \\
\hline Deficiency & Fixed & Deficiency & Fixed & Deficiency & Fixed & Deficiency & Fixed \\
\hline $\begin{array}{c}\text { No } \\
\text { deficiencies } \\
\text { in 1990 }\end{array}$ & & $\begin{array}{c}\text { No } \\
\text { deficiencies } \\
\text { in } 1991\end{array}$ & & $\begin{array}{c}\text { No } \\
\text { deficiencies } \\
\text { in 1992 }\end{array}$ & & $\begin{array}{c}\text { No } \\
\text { deficiencies } \\
\text { in 1993 }\end{array}$ \\
\hline $\begin{array}{c}\text { Total } \\
0\end{array}$ & 0 & 0 & 0 & 0 & & & 0 \\
\hline
\end{tabular}

Table XLVI. QP-15.2 (R1)

\begin{tabular}{|c|c|c|c|c|c|c|c|}
\hline \multicolumn{2}{|c|}{1990} & \multicolumn{2}{|c|}{1991} & \multicolumn{2}{|c|}{1992} & \multicolumn{2}{|c|}{1993} \\
\hline Deficiency & Fixed & Deficiency & Fixed & Deficiency & Fixed & Deficiency & Fixed \\
\hline $\begin{array}{l}\text { DR } 114 \\
\text { R1, 6.7.5 } \\
\text { DR } 121 \\
\text { R1, 6.3.1 } \\
\text { DR } 127 \\
\text { R1, 6.7.3 }\end{array}$ & $\begin{array}{l}\text { YA- } \\
90-01-8 \\
\text { R1 }\end{array}$ & $\begin{array}{l}\text { DR } 158 \\
\text { R1, } 7.0 \\
\text { DR } 186 \\
\text { R1, 6.7.4.3 }\end{array}$ & $\begin{array}{l}\text { YA- } \\
91-03-5 \\
\text { R1 } \\
\text { YA- } \\
91-03-6 \\
\text { R1 }\end{array}$ & $\begin{array}{c}\text { No } \\
\text { deficiencies } \\
\text { in } 1992\end{array}$ & & $\begin{array}{c}\text { No } \\
\text { deficiencies } \\
\text { in } 1993\end{array}$ & \\
\hline $\begin{array}{r}\text { Total } \\
3 \\
\end{array}$ & 1 & 2 & 2 & 0 & 0 & 0 & 0 \\
\hline
\end{tabular}

Table XLVII. QP-16.2 (R2)

\begin{tabular}{|c|c|c|c|c|c|c|c|}
\hline \multicolumn{2}{|c|}{1990} & \multicolumn{2}{|c|}{1991} & \multicolumn{2}{|c|}{1992} & \multicolumn{2}{|c|}{1993} \\
\hline Deficiency & Fixed & Deficiency & Fixed & Deficiency & Fixed & Deficiency & Fixed \\
\hline $\begin{array}{l}\text { DR } 056 \\
\text { RO, } 6.1 .1 \text {, } \\
\text { CR } 123 \\
\text { SDR } 597, \\
\text { RO }\end{array}$ & & $\begin{array}{c}\text { No } \\
\text { deficiencies } \\
\text { in } 1991\end{array}$ & & $\begin{array}{c}\text { No } \\
\text { deficiencies } \\
\text { in } 1992\end{array}$ & & $\begin{array}{c}\text { No } \\
\text { deficiencies } \\
\text { in } 1993\end{array}$ & \\
\hline Total & & & & & & & \\
\hline 2 & 0 & 0 & 0 & 0 & 0 & 0 & 0 \\
\hline
\end{tabular}


Table XLVIII. QP-16.3 (R1)

\begin{tabular}{||c|c|c|c|c|c|c|c||}
\hline \multicolumn{2}{|c|}{1990} & \multicolumn{2}{c|}{1991} & \multicolumn{2}{c|}{1992} & \multicolumn{2}{c||}{1993} \\
\hline Deficiency & Fixed & Deficiency & Fixed & Deficiency & Fixed & Deficiency & Fixed \\
\hline $\begin{array}{c}\text { Not } \\
\text { applicable }\end{array}$ & & $\begin{array}{c}\text { Not } \\
\text { applicable }\end{array}$ & & $\begin{array}{c}\text { No } \\
\text { deficiencies } \\
\text { in 1992 }\end{array}$ & $\begin{array}{c}\text { No } \\
\text { deficiencies } \\
\text { in 1993 }\end{array}$ & & \\
\hline Total & 0 & 0 & 0 & 0 & 0 & 0 & 0 \\
\hline
\end{tabular}

Table XLIX. QP-17.1 (R0)

\begin{tabular}{|c|c|c|c|c|c|}
\hline \multicolumn{2}{|c|}{1990} & \multicolumn{2}{|c|}{1991} & \multicolumn{2}{|c|}{1992} \\
\hline Deficiency & Fixed & Deficiency & Fixed & Deficiency & Fixed \\
\hline $\begin{array}{c}\text { No } \\
\text { deficiencies } \\
\text { in } 1990\end{array}$ & & $\begin{array}{l}\text { DR } 164 \\
\text { R1, 6.2.3 } \\
\text { DR 170 } \\
\text { R1, } 6.7 .3 .5 \\
\text { DR } 183 \\
\text { R1, } 6.4 .1 \\
\end{array}$ & & & $\begin{array}{l}\text { Superceded } \\
\text { by } Q P-17.3\end{array}$ \\
\hline $\begin{array}{r}\text { Total } \\
0\end{array}$ & 0 & 3 & 0 & 0 & 0 \\
\hline
\end{tabular}


Table L. QP-17.3 (R0)

\begin{tabular}{|c|c|c|c|c|c|}
\hline \multicolumn{2}{|c|}{1990} & \multicolumn{2}{|c|}{1991} & \multicolumn{2}{|c|}{1992} \\
\hline Deficiency & Fixed & Deficiency & Fixed & Deficiency & Fixed \\
\hline 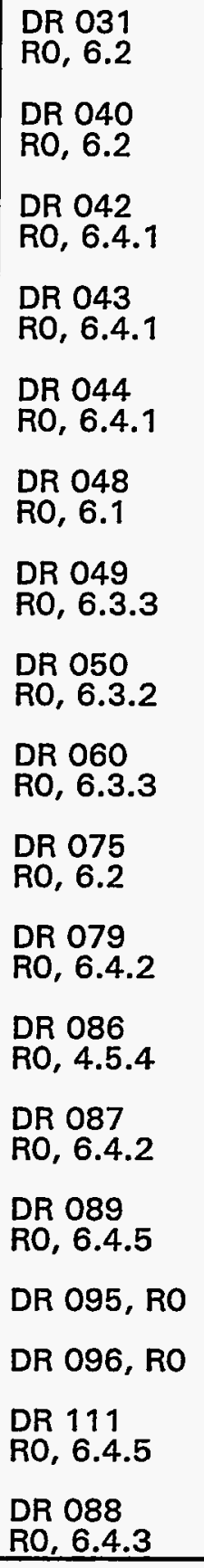 & $\begin{array}{l}91-001-04 \\
\mathrm{R} 1,6.2 .1 \\
91-002-1 \\
\mathrm{R} 1,6.2 .1 \\
91-003-1 \\
\mathrm{R} 1,6.6 .3\end{array}$ & $\begin{array}{l}\text { DR } 129 \\
\text { RO, 6.5.4 } \\
\text { DR } 130 \\
\text { R0, 6.4.6 } \\
\text { DR 133 } \\
\text { R1, 6.3.5.1, } \\
6.3 .5 .6, \\
6.6 .3 \\
\text { DR 138, R1 } \\
\text { DR 142 } \\
\text { R0, 6.0 } \\
\text { SWO-LA07 } \\
\text { R0, 6.10 } \\
\text { DR 164 } \\
\text { R1, 6.2.3 } \\
\text { DR 170 } \\
\text { R1, 6.7.3.5 } \\
\text { DR 183 } \\
\text { R1, 6.4.1 } \\
\text { DR 165 } \\
\text { R1, 6.10.3 }\end{array}$ & $\begin{array}{l}91-12-8 \\
R 1,6.2 .2 \\
91-001-04 \\
R 1,6.2 .1 \\
91-002-1 \\
R 1,6.2 .1 \\
91-003-1 \\
R 1,6.6 .3\end{array}$ & $\begin{array}{l}\text { DR } 204 \\
17.4, \text { RO } \\
6.9 .2\end{array}$ & $\begin{array}{l}\text { YA- } \\
92-12-02, \\
\text { R1, } \\
6.2,6.2 .1 \\
\text { YA- } \\
92-12-03, \\
\text { R1 } \\
\text { Att. } 3 \\
\text { Superceded } \\
\text { by } \\
\text { OPs-17.4 } \\
\text { and }-17.5\end{array}$ \\
\hline $\begin{array}{l}\text { Total } \\
18 \\
\end{array}$ & 3 & 10 & 4 & 1 & 2 \\
\hline
\end{tabular}


Table LI. QP-17.4 (RO)

\begin{tabular}{|c|c|c|c|c|c|c|c|}
\hline \multicolumn{2}{|c|}{1990} & \multicolumn{2}{|c|}{1991} & \multicolumn{2}{|c|}{1992} & \multicolumn{2}{|c|}{1993} \\
\hline Deficiency & Fixed & Deficiency & Fixed & Deficiency & Fixed & Deficiency & Fixed \\
\hline $\begin{array}{c}\text { Not } \\
\text { applicable }\end{array}$ & & $\begin{array}{c}\text { Not } \\
\text { applicable }\end{array}$ & & $\begin{array}{l}\text { DR } 202 \\
\text { RO, } 6.3 .2 \\
\text { DR } 204 \\
\text { RO, } 6.9 .2\end{array}$ & & $\begin{array}{l}\text { DR } 216 \\
\text { RO, } 9.0 \\
\text { DR } 223 \\
\text { RO, } 6.1,6.3\end{array}$ & $\begin{array}{l}93-02-01 \\
\text { RO } \\
93-06-02 \\
\text { RO, 6.3.5 } \\
93-09-06 \\
\text { Ro, 6.3.5 } \\
93-12-06 \\
\text { RO, 6.4.1 }\end{array}$ \\
\hline $\begin{array}{l}\text { Total } \\
\quad 0\end{array}$ & 0 & 0 & 0 & 2 & 0 & 2 & 4 \\
\hline
\end{tabular}

Table LII. QP-17.5 (R0)

\begin{tabular}{|c|c|c|c|c|c|c|c|}
\hline \multicolumn{2}{|c|}{1990} & \multicolumn{2}{|c|}{1991} & \multicolumn{2}{|c|}{1992} & \multicolumn{2}{|c|}{1993} \\
\hline Deficiency & Fixed & Deficiency & Fixed & Deficiency & Fixed & Deficiency & Fixed \\
\hline $\begin{array}{c}\text { Not } \\
\text { applicable }\end{array}$ & & $\begin{array}{c}\text { Not } \\
\text { applicable }\end{array}$ & & $\begin{array}{l}\text { DR } 202 \\
\text { RO, } 6.2 .3\end{array}$ & $\begin{array}{l}92-07-001 \\
\text { RO, } \\
6.2 .2 .2\end{array}$ & $\begin{array}{l}\text { DR } 218 \\
\text { RO, } 6.1 .2\end{array}$ & \\
\hline Total & & & & & & & \\
\hline 0 & 0 & 0 & 0 & 1 & 1 & 1 & 0 \\
\hline
\end{tabular}

Table LIII. QP-18.1 (R4)

\begin{tabular}{|c|c|c|c|c|c|c|c|}
\hline \multicolumn{2}{|c|}{1990} & \multicolumn{2}{|c|}{1991} & \multicolumn{2}{|c|}{1992} & \multicolumn{2}{|c|}{1993} \\
\hline Deficiency & Fixed & Deficiency & Fixed & Deficiency & Fixed & Deficiency & Fixed \\
\hline & $\begin{array}{l}\text { YA- } \\
90-01-5 \\
\text { R4 }\end{array}$ & $\begin{array}{l}\text { DR } 143 \\
\text { R4, } 6.5 \\
\text { DR } 151 \\
\text { R4,6.5 } \\
\end{array}$ & & $\begin{array}{c}\text { No } \\
\text { deficiencies } \\
\text { in } 1992\end{array}$ & & $\begin{array}{c}\text { No } \\
\text { deficiencies } \\
\text { in } 1993\end{array}$ & \\
\hline $\begin{array}{l}\text { Total } \\
0\end{array}$ & 1 & 2 & 0 & 0 & 0 & 0 & 0 \\
\hline
\end{tabular}


Table LIV. QP-18.2 (R2)

\begin{tabular}{|c|c|c|c|c|c|c|c|}
\hline \multicolumn{2}{|c|}{1990} & \multicolumn{2}{|c|}{1991} & \multicolumn{2}{|c|}{1992} & \multicolumn{2}{|c|}{1993} \\
\hline Deficiency & Fixed & Deficiency & Fixed & Deficiency & Fixed & Deficiency & Fixed \\
\hline & $\begin{array}{l}\text { YA- } \\
90-01-9 \\
\text { RO }\end{array}$ & $\begin{array}{l}\text { DR } 138 \\
\text { R0, } 7.1\end{array}$ & $\begin{array}{l}\text { YA- } \\
91-03-8 \\
\text { R2 } \\
\text { YA- } \\
\text { 91-03-9 } \\
\text { R2 }\end{array}$ & $\begin{array}{l}\text { DR } 194 \\
\text { R1, } 6.3 .1, \\
6.3 .3\end{array}$ & & $\begin{array}{c}\text { No } \\
\text { deficiencies } \\
\text { in } 1993\end{array}$ & \\
\hline Total & & & & & & & \\
\hline 0 & 1 & 1 & 2 & 1 & 0 & 0 & 0 \\
\hline
\end{tabular}

Table LV. QP-18.3 (R2)

\begin{tabular}{|c|c|c|c|c|c|c|c|}
\hline \multicolumn{2}{|c|}{1990} & \multicolumn{2}{|c|}{1991} & \multicolumn{2}{|c|}{1992} & \multicolumn{2}{|c|}{1993} \\
\hline Deficiency & Fixed & Deficiency & Fixed & Deficiency & Fixed & Deficiency & Fixed \\
\hline & $\begin{array}{l}\text { YA- } \\
90-01-11 \\
\text { RO }\end{array}$ & & $\begin{array}{l}\text { YA- } \\
91-03-7 \\
\text { R2 }\end{array}$ & & $\begin{array}{l}\text { YA- } \\
\text { 92-19-04, } \\
\text { R2 }\end{array}$ & $\begin{array}{c}\text { No } \\
\text { deficiencies } \\
\text { in } 1993\end{array}$ & \\
\hline Total & & & & & & & \\
\hline 0 & 1 & 0 & 1 & 0 & 1 & 0 & 0 \\
\hline
\end{tabular}

